\title{
References and Index
}


Hans Teye Bakker - 9789004412071

Downloaded from Brill.comø4/26/2023 $04: 27: 16 \mathrm{AM}$

via free access 


\section{LIST OF FIGURES}

1 Gupta-Vākātaka matrimonial relations . . . . . . . . . . . . . . . . . . . . . 115

2 Historical map of Mekalā and Dakșina Kosala . . . . . . . . . . . . . . . . . 237

3 Dynasties of Mekalā and Dakṣina Kosala . . . . . . . . . . . . . . . . . . . . 238

4 Dynastic capitals of Mekalā and Dakṣiṇa Kosala . . . . . . . . . . . . . . . . 238

5 Genealogy of the Gupta and Vākāṭaka dynasties . . . . . . . . . . . . . . . . 318

6 Map of Vidarbha and surrounding countries . . . . . . . . . . . . . . . . . . 347

7 Gupta Vākātaka relationship as known before the KNT Inscription . . . . . . . 359

8 Gupta Vākātaka relationship as deduced from the KNT Inscription . . . . . . . 360

9 The Gupta Vākātaka relationship . . . . . . . . . . . . . . . . . . . . . . . 362

10 The Maukharis of Kanauj . . . . . . . . . . . . . . . . . . . . . . . . . . . 382

11 Survey map of Mansar. Based on T.A. Wellsted 1934,

Plan of Old Town Site Mansar . . . . . . . . . . . . . . . . . . . . . . . . . 432

12 Avimuktakṣetra. The twelve linga sanctuaries encircling Avimukteśvara.

Map made by Niels Gutschow . . . . . . . . . . . . . . . . . . . . . . . . . 472

13 Bāṇa's pedigree .. . . . . . . . . . . . . . . . . . . . . . . . . . 536

14 Matrimonial alliances of the royal houses of North India in the 6 th and 7 th centuries . . . . . . . . . . . . . . . . . . . . . . 538

15 Map of northwestern India: spread of the Pāśupata movement.

After Bartholomew (Edinburgh), 'Indian Subcontinent' . . . . . . . . . . . . . 565

\section{LIST OF PLATES}

All photos were taken by the author, unless stated otherwise

1 Illiers-Combray: La maison où Tante Léonie achetait ses madeleines . . . . . . . 53

2 Ayodhyā: Hanumāngaṛh̄̄ (before 1870) After Carnegy 1870 . . . . . . . . . . . 67

3 Ayodhyā: Monks of the Hanumāngaṛh̄̄ (before 1870) After Carnegy 1870 . . . . . 67

4 Ayodhyā: Babri Masjid (before 1870). After Carnegy 1870 . . . . . . . . . . . . . 69

5 Nasik: Consecration of bricks for the Rāmajanmabhūmi Temple . . . . . . . . . . 74

6 Ramtek: Graffito on an entrance pillar of the Kevala-Narasimha Temple . . . . . 82

7 Ramtek: Graffito on a pillar inside the Kevala-Narasiṃha Temple . . . . . . . . 82

8 Ramtek: Kevala-Narasiṃha Temple Ramtek Inscription No. 1 . . . . . . . . . . 84

9 Ramtek: Kevala-Narasiṃha Temple Ramtek Inscription No. 2 . . . . . . . . . . 87

10 Ramtek: Vākāṭaka Inscription in the Kevala-Narasiṃha Temple . . . . . . . . 117

11 Ramtek: Varāha Temple . . . . . . . . . . . . . . . . . . . . . . . . . . . . 156

12 Ramtek: Rāmacandra and Lakṣmaṇa temples on the spur of the Rāmagiri . . . . 166

13 Paunar: Kamsavadha . . . . . . . . . . . . . . . . . . . . . . . . . . . . . 171

14 Paunar: Dhenukāsuravadha . . . . . . . . . . . . . . . . . . . . . . . . . . 171

15 Paunar: Little Kṛṇa's play with the moon . . . . . . . . . . . . . . . . . . . 172

16 Rajim: Panels on 'Rucaka' pillar (north side) in the Rāmacandra Temple . . . . 246

17 Turturiya: Pillar at the entrance of temple in Turturiya . . . . . . . . . . . . . 246

18 Sirpur Site Museum Lakṣmaṇa Temple: Narasiṃha . . . . . . . . . . . . . . . 254

19 Tālā: Devarān̄̄ Temple seen from the south . . . . . . . . . . . . . . . . . . . 257 
20 Tālā: Jithān̄̄ Temple seen from the south . . . . . . . . . . . . . . . . . . . 257

21 Tālā: Brick buttresses at the western side of the Jithān̄̄ Temple . . . . . . . . . 258

22 Tālā: Image (with uṣñ̄ṣa?) lying west of the Jiṭhān̄̄ Temple . . . . . . . . . . 266

23 Tālā: Image of Narasiṃha on architrave lying southwest of the Jițān̄̄ Temple $\quad 266$

24 Tālā: Bhārarakṣakas supporting central entrance pillar of the Jiṭhān̄̄ Temple . 267

25 Tālā: Lions supporting outer entrance pillar of Jițhān̄̄ Temple . . . . . . . . . 267

26 Tālā: Base of central entrance pillar of Jiṭhān̄̄ Temple . . . . . . . . . . . . . 268

27 Tālā: Pillar lying at the western entrance of the Jithān̄̄ Temple . . . . . . . . . 269

28 Tālā: Mouse/rat on pillar at the western entrance of the Jițān̄̄ Temple . . . . . 269

29 Tālā: Eastern side of the Jițān̄̄ Temple . . . . . . . . . . . . . . . . . . . . 269

30 Tālā: Rear side of pillar at eastern entrance of Jiṭān̄̄ Temple . . . . . . . . . 270

31 Tālā: Figure at eastern entrance of Jiṭhān̄̄ Temple . . . . . . . . . . . . . . . 270

32 Tālā: Elephant's head at the northern side of the Jiṭhān̄̄ Temple . . . . . . . . 271

33 Tālā: Gaṇeśa at the northern side of the entrance of the Devarān̄̄ Temple . . . . 272

34 Tālā: Supporting makara head and gaṇa (Jiṭhān̄̄ Temple) . . . . . . . . . . . 273

35 Tālā: Supporting makara (Jiṭhān̄̄ Temple) . . . . . . . . . . . . . . . . . . . 274

36 Tālā: Supporting gaṇa (Jiṭhān̄̄ Temple) . . . . . . . . . . . . . . . . . . . . 274

37 Tālā: Supporting gaṇas (Jiṭhān̄̄ Temple) . . . . . . . . . . . . . . . . . . . . 275

38 Tālā: Gaṇa supporting standing image (Jiṭhān̄̄ Temple) . . . . . . . . . . . . 275

39 Tālā: Supporting gaṇa (Jiṭhān̄̄ Temple) . . . . . . . . . . . . . . . . . . . . . . . 276

40 Tālā: Image standing at the southern staircase of the Jiṭhān̄̄ Temple . . . . . . 277

41 Tālā: Broken right underarm of image at southern entrance of the Jithān̄̄ Temple . . . . . . . . . . . . . . . . . . . . . . . . . . . . . 278

42 Tālā: Sculpture on top of the Jiṭhān̄̄ Temple mound . . . . . . . . . . . . . . . 279

43 Tālā: Profile of the head of the minor figure of the sculpture on top of the Jițān̄̄ Temple mound . . . . . . . . . . . . . . . . . . . . . . . . . . . . . 280

44 Tālā: Naigameșa standing to the left (south) of the entrance of the Devarān̄̄ Temple . . . . . . . . . . . . . . . . . . . . . . . . . . . . . . 281

45 Mandhal: Naigameșa image found in Mandhal excavations (Vidarbha) . . . . . 282

46 Kumāragupta: Apratigha Type gold coin. BM 1884,0404.1. Photograph courtesy British Museum via Ellen Raven. . . . . . . . . . . . . . 309

47 Signet-ring of Mahārāja Maheśvaranāga, son of Nāgabhaț̣a,

A \& B (mirrored). BM 1892,1103.91. Photo courtesy British Museum . . . . . . 313

48 Skandagupta: King-and-Lady Type gold coin. BM 1847,1201.369.

Photograph courtesy British Museum via Ellen Raven. . . . . . . . . . . . . . 316

49 Mansar (MNS 2): Seal of Prabhāvatī: śrīprabhākā, A \& B (mirrored). . . . . . . 331

50 Mansar (MNS 2): Seal of Pravarasena: pravarasya, A \& B (mirrored). . . . . . . 331

51 The Rāmagiri . . . . . . . . . . . . . . . . . . . . . . . . . . . . . . . 338

52 Ramtek: The Dhūmreśvara Temple . . . . . . . . . . . . . . . . . . . . . . . 338

53 Ramtek: The Rāma and Lakșmaṇa temples on Rāma's Hill . . . . . . . . . . . 339

54 Nagardhan: Footprint tablet . . . . . . . . . . . . . . . . . . . . . . . . . . 341

55 Ramtek: Viṣnu Trivikrama . . . . . . . . . . . . . . . . . . . . . . . . . . . 342

56 Nagardhan: Miniature Narasimha . . . . . . . . . . . . . . . . . . . . . . . 344

57 Ramtek: Narasimha in the Kevala-Narasimha Temple . . . . . . . . . . . . . 345

58 Ramtek: Narasimha in the Rudra-Narasimha Temple . . . . . . . . . . . . . . 345

59 Rajim, Rājīvalocana Temple: Narasiṃha slaying the demon Hiraṇyakaśipu . . . 346

60 Sindursi: Narasimhha carved in the rock . . . . . . . . . . . . . . . . . . . . . 348

61 Garh-Dhanora: Two Narasimha images. Photo courtesy L.S. Nigam . . . . . . . 348

62 Sirpur: Narasimha image . . . . . . . . . . . . . . . . . . . . . . . . . . . . 349

63 View of the Vākātaka temples on the Rāmagiri. Courtesy of Google Earth. . . . 366 
64 Ruins of the Trivikrama Temple, Rāmagiri (view to the east) . . . . . . . . . . 366

65 Ramtek: Main image of the Trivikrama Temple . . . . . . . . . . . . . . . . . 367

66 Ramtek: Pillar with anchor-shaped element at the bottom (Trivikrama Temple) . 368

67 Deogarh: Ornamented pillar of the temple in Deograh.

Photo courtesy Joanna Williams . . . . . . . . . . . . . . . . . . . . . . . . 368

68 Ramtek: Relief at the bottom of the Trivikrama sculpture . . . . . . . . . . . 369

69 Ramtek: Relief at the bottom of the Trivikrama sculpture (lined-out) . . . . . . 369

70 Ramtek: Contour of Bali's wife at his right side . . . . . . . . . . . . . . . . . 369

71 Ramtek: King Bali underneath the stretched leg of Trivikrama . . . . . . . . . 369

72 Ramtek: Lower leg visible of Vāmana between Bali and Trivikrama . . . . . . . 370

73 Pawaya: Trivikrama lintel. After Williams 1982 (Pl. 50) . . . . . . . . . . . . . 370

74 View of the reservoir Sudarśana (Khindsi Lake) from the Trivikrama Temple on the top of the Rämagiri . . . . . . . . . . . . . . . . . . . . . . . . . . . 372

75 Mansar: Sealing (seal impression) found in MNS 3 reading: pravareśvara . . . . 374

76 Bhitari: Pillar with Skandagupta's inscription and adjacent excavation of site 2 . . . . . . . . . . . . . . . . . . . . . . . . . . . . . . . . . 378

77 Fragmentary Maukhari Inscription found in Jaunpur. After CII III (1888), Plate xxxii . . . . . . . . . . . . . . . . . . . . . . . . 384

78 Francis Buchanan: Sketch of the ruins of the Temple of Mundeswari, AD 1813. After Martin 1838, Vol. I, opposite p. 474 (Pl. V No. 1) . . . . . . . . 392

79 Daniell: Drawing of 'The Temple of Mandeswara near Chaynpore, Bahar', AD 1790. Courtesy of the British Library. . . . . . . . . . . . . . . . . . . . . 392

80 Daniell: Drawing of 'Interior of the temple of Mandeswara near Chaynpore, Bahar', AD 1790. Courtesy of the British Library. . . . . . . . . . . . . . . . . 393

81 The Caturmukhalinga inside the temple on Mundesvari Hill in AD 2008. Photo courtesy Yuko Yokochi . . . . . . . . . . . . . . . . . . . 393

82 Muṇdeśvarī Inscription, Year 30. Estampage in Epigraphia Indica IX . . . . . . 395

83 Muṇdeśvarī: Old Caturmukhalinga in the compound of the Muṇdeśvarī Temple . 402

84 Mundeśvarī: Ekamukhalinga of site A, presently stored within the Muṇdeśvarī Temple. Photo courtesy of F. Buckee (2008) . . . . . . . . . . . . 402

85 Ahicchatra (AC I) during excavation (1940-44). Photo courtesy ASI . . . . . . 420

86 Mansar (MNS 3) in 1999 . . . . . . . . . . . . . . . . . . . . . . . . . . . . 422

87 Mansar, MNS 3: 'The Man of Mansar'. Photograph by the venerable Sasai (27-3-1998) . . . . . . . . . . . . . . . . . . . . . . . . 423

88 Kāfir-koṭ (Gandhāra): Sudāya meets the Buddha. BM 1899,0609.22. Photo courtesy British Museum. (Zwalf 1996 I, 201 f., Plate 225) . . . . . . . . 424

89 Sui Vihar Stūpa in Bahawalpur. After Indian Antiquary X (1881) facing p. 324 . . . . . . . . . . . . . . . . . . . . . . . . 426

90 Wooden pillar Lauriya-Nandangarh, mound N . . . . . . . . . . . . . . . . . 428

91 Nāga (front and back) found at site T in Mansar. BM 1930,10.7.1. Photo courtesy British Museum . . . . . . . . . . . . . . . . . . . . . . 433

92 Mansar: Pottery found at site T in Mansar. BM 1930,10.7.2-25. Photo courtesy British Museum . . . . . . . . . . . . . . . . . . . . . . . . 434

93 (left) Nāga image in front of the Kevala-Narasiṃha Temple Rāmagiri, (right) Nāga Mansar site T, BM 1930,10.7.1 . . . . . . . . . . . . . . . . . . 435

94 Tomb of the mother of Sudāya and the latter's meeting with the Buddha. After de Marco 1987, 210, Fig. 12. Present location unknown . . . . . . . . . . 436

95 Funerary monument in the śmaśāna; from a three-panelled Gandhāra relief kept in the Victoria and Albert Museum (IS.1-1945). Photo courtesy of the Victoria and Albert Museum . . . . . . . . . . . . . . . 438

96 Jagatgram: Altar Site I. After Indian Archaeology-A Review 1953-54, Plate XIII A . . . . . . . . . . . . . . . . . . . . . . . . . . . . . . . . . . 448 
97 Jagatgram: Five layers of brick forming the Agnicayana altar.

After Indian Archaeology-A Review 1953-54, Plate XIV A . . . . . . . . . . . 451

98 Inscribed brick from Jagatgram. After Indian Archaeology-A Review

1953-54, Plate XV(2) . . . . . . . . . . . . . . . . . 452

99 'General View of the Kauśāmbī excavations (1957-59), the Śyenaciti

in the foreground'. After Sharma 1960, Excavations at Kauśāmbī, Plate 12 . . . 453

100 Kauśāmbī excavation: 'Human skull on the tail of the Śyenaciti'.

After Sharma 1960, Excavations at Kauśāmbī, Plate 33 B . . . . . . . . . . . . 454

101 Kauśāmbī excavation: Iron Snake. After Sharma 1960, Excavations at

Kauśāmbī, Plate 43 No. 38 . . . . . . . . . . . . . . . . . . . . . . . 454

102 Mansar, MNS 3 (Hiḍimbā Ṭekḍ̂̄): Altar Site . . . . . . . . . . . . . 456

103 Mansar, MNS 3: Man of Mansar (Manasarapurusa) . . . . . . . . . . . . . 457

104 Mansar, MNS 3: snake at the left foot of the Manasarapurușa . . . . . . . . . 458

105 Mansar, MNS 3: Breast of the Manasarapuruṣa with hole to fix Vāstoṣpati . . 459

106 Human figure underneath temple in Kandhar. After Indian

Archaeology-A Review 1983-84, Plate 45 . . . . . . . . . . . . . . . . . . . 461

107 Curdi: Human figure with child. Photo courtesy Frans Janssen . . . . . . . . 462

108 Curdi: child underneath left arm (detail of Plate 107).

Photo courtesy Frans Janssen . . . . . . . . . . . . . . . . . 462

109 Image found in Bhita. State Museum Lucknow: H4.

Photo courtesy D.M. Srinivasan 1997. . . . . . . . . . . . . . . . . . . 491

110 Mathurā: Caturmukhalinga. National Museum (Delhi): 65.172.

Photo courtesy D.M. Srinivasan 1997. . . . . . . . . . . . . . 492

111 Mathurā: Architrave with scene of linga worship. Government Museum

Mathura: 3625. Courtesy Government Museum Mathura. . . . . . . . . . . . 493

112 Mathurā: Pilaster. Government Museum Mathura: 1931.

Courtesy Government Museum Mathura. . . . . . . . . . . . . . . . . 494

113 Mansar: Caturbhuja Śiva. National Museum (Delhi): L-77/2.

Courtesy National Museum. . . . . . . . . . . . . . . . . . . . . . . 495

114 Tiruttani: Dakṣināmūrti on the outer southern wall of the garbhagrha of the Vīratțāneśvara Temple. After Dumarçay \& l'Hernault 1975, photo 54 . . . . . . 522

115 Nagarī: Crossbar of torana (obverse). Photo courtesy Joanna G. Williams. . . . 523

116 Nagarī: a Dakṣinamūrti. Photo courtesy Joanna G. Williams. . . . . . . . . . . 525

117 Thanesar: Excavations at the Harṣa kā Ṭilā. . . . . . . . . . . . . . . . . . 528

118 Mathurā: Lakulīśa with two pupils. . . . . . . . . . . . . . . . . . . . . 530

119 Thanesar: Sthāṇuvața at the Stānutīrtha. . . . . . . . . . . . . . . . . . . . 535

120 Symeons's entry into the city of Emesa. . . . . . . . . . . . . . . . . 547

121 Mathurā: Club-bearing ascetic. After Michael Meister (ed.) 1984. . . . . . . . . 555

122 Mathurā: Lakulīśa. After Michael Meister (ed.) 1984. . . . . . . . . . . . . . . 555

123 Aï Khanum: Heracles. After Afghanistan 2008. . . . . . . . . . . . . . . . . . 556

124 Mathurā: Heracles and the Nemeian lion (Mathura Museum).

After Vogel 1930. . . . . . . . . . . . . . . . . . . . . . 556

125 Aï Khanum: Heracles' club (left) \& Mathurā: Lakulīśa's club (right).

Details of Plates $122 \& 123 . \quad$. . . . . . . . . . . . . . . . . . 557

126 Daṇ̣apāṇi on Mathurā pilaster, Ge 61 (Mathura Museum). . . . . . . . . . . 558

127 Ujjain: The Cremation Ground. After Garde 1940. . . . . . . . . . . . . . 560

128 Yogeśvarī Cave (Mumbai): Lakulīśa with four disciples. . . . . . . . . . . . . . 561

129 The citadel of the old town of Madhyamikā. Courtesy Google Earth Pro. . . . . . 567

130 Nagarī: The site of the Mahādeva Temple. Courtesy Google Earth Pro. . . . . . 568

131 Nagarì: Remains within the precincts of the Mahādeva Temple. . . . . . . . . . 568

132 Nagarī: Torana east face. . . . . . . . . . . . . . . . . . . . 569 
133 Nagarī: Torana west face. . . . . . . . . . . . . . . . . . . . . . . . . . . . 569

134 Nagarī: Liñga of Mahādeva Temple. . . . . . . . . . . . . . . . . . . . . . . 572

135 Nagarī: Excavated brick platform. . . . . . . . . . . . . . . . . . . . . . 572

136 Nagarī: Side face of the torana post. . . . . . . . . . . . . . . . . . . . . . . 574

137 Nagarī: Gatekeeper with trident facing east, at the bottom of the torana post. . . 574

138 Nagarī: Candraśālā arches in the second tier of the toraṇa. . . . . . . . . . . . 574

139 Miniature temple; detail of Plate 138. . . . . . . . . . . . . . . . . . . . . . 575

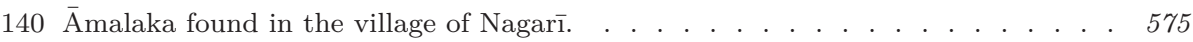

141 Nagarī: Architrave of the gateway, facing east. . . . . . . . . . . . . . . . . . 575

142 Nagarī: Reconstruction of the architrave of the gateway, facing east.

Drawing by Véronique Degroot. . . . . . . . . . . . . . . . . . . . . . . . . 575

143 Nagarī: The first panel of the eastern face of the architrave (E 1). . . . . . . . . 577

144 Malhar: Lower-most panel in the doorpost of the Deur Temple.

Photo courtesy Natasja Bosma. . . . . . . . . . . . . . . . . . . . . . . . . 578

145 Nagarī: Second panel from the left of the eastern face of the architrave (E 2). . . 579

146 Nagarī: Third panel from the left of the eastern face of the architrave (E 3). . . . 579

147 Fertility goddess. Government Museum, Mathura: Acc. No. 11.151. . . . . . . . 580

148 Ahicchatra: Gañgā. National Museum, Delhi: Acc. No. L. 2.

Photo courtesy National Museum. . . . . . . . . . . . . . . . . . . . . . . . 580

149 Ahicchatra: Terracotta panel. Photo courtesy Laxshmi Greaves. . . . . . . . . . 581

150 Nagarī: Second panel from left (E 2). . . . . . . . . . . . . . . . . . . . . . . 582

151 Malhar: Second panel from bottom in the doorpost of the Deur Temple.

Photo courtesy Natasja Bosma. . . . . . . . . . . . . . . . . . . . . . . . . 582

152 Nagarī: Third panel from left of the eastern face of the architrave (E 3). . . . . . 582

153 Malhar: Third panel from bottom in the doorpost of the Deur Temple.

Photo courtesy Natasja Bosma. . . . . . . . . . . . . . . . . . . . . . . . . 582

154 Nagarī: Fourth panel from the left of the eastern face of the architrave (E 4). . . 583

155 Nagarī: Fifth panel from the left of the eastern face of the architrave (E 5). . . . 585

156 Nagarī: Sixth panel from the left of the eastern face of the architrave (E 6):

a Dakṣināmūrti. . . . . . . . . . . . . . . . . . . . . . . . . . . . . . . . . 586

157 Nagarī: Architrave of the gateway, facing west. . . . . . . . . . . . . . . . . . 587

158 Nagari: Reconstruction of the architrave of the gateway, facing west.

Drawing by Véronique Degroot. . . . . . . . . . . . . . . . . . . . . . . . . 587

159 Nagarī: First panel on the western face of the architrave (W 1). . . . . . . . . . 588

160 Deogarh: Panel on the eastern face of the temple.

Photo courtesy Michael Willis. . . . . . . . . . . . . . . . . . . . . . . . . . 588

161 Nagarī: Second panel from left on the western face of the architrave (W 2). . . . 590

162 Nagarī: Third panel from left on the western face of the architrave (W 3). . . . . 591

163 Nagarī: Fourth panel from left on the western face of the architrave (W 4).

Arjuna's bow-fight with the Kirāta. . . . . . . . . . . . . . . . . . . . . . . 592

164 Nagarī: Fifth panel from left on the western face of the architrave (W 5).

Arjuna assails the Kirāta. . . . . . . . . . . . . . . . . . . . . . . . . . . . 592

165 Nagarī: Sixth panel from left on the western face of the architrave (W 6).

Arjuna receives the Pāśupata weapon. . . . . . . . . . . . . . . . . . . . . . 593

166 Rajaona: Panel on column: the presentation of the Pāśupata Weapon.

Photo courtesy American Institute of Indian Studies. . . . . . . . . . . . . . . 596

167 Nagarī: Begging bowls in panels 1, 2,3 (east), and in panel 2 (west)

of the architrave. . . . . . . . . . . . . . . . . . . . . . . . . . . . . . . . 596

168 Detail of Plate 159 (W 1): the Pāśupata Weapon? . . . . . . . . . . . . . . . 597 


\section{BIBLIOGRAPHY}

Abhayadeva Sūri

Commentary (Vivarana) at the Sthānasūtra (Thānasuya), edit. by Sudharma Svamin. Bombay/Mehesana 1918-1919. 2 vols. Āgamodaya Samiti.

Commentary (Vivarana) at the Antakrddaśā (Antagadadasāo), Anuttaropapātikadaśā (Anuttarovavāiyadasāo), and Vipākasūtra Bombay/Mehesana 1921. Āgamodaya Samiti.

Abhinavagupta

Tantrāloka with Commentary by Rājānaka Jayaratha edited with notes by Mukund Rām Shāstrī Vol. I. Allahabad 1918. Kashmir Series of Texts and Studies XXIII.

Abu 'l-Fazl

The Akbar Nāma. History of the reign of Akbar including an account of his predecessors. Translated from the Persian by H. Beveridge. Indian reprint, Delhi 1973. 3 vols.

Acharya, Diwakar

1997 Madhyakālamā Nepāla āekā Yogī Śankkarācārya hoinan. in: Rُtambharā (Journal of the Research Centre of Mahendra Sanskrit University) Vol. II.2 (1997), 76-88, Vol. II.3, 86-96.

2005 The Role of Canḍa in the Early History of the Pāśupata Cult and the Image on the Mathurā Pillar dated Gupta Year 61. in: IIJ 48 (2005), 207-222.

2007 The Samskāravidhi: A Manual on the Transformatory Rite of the Lakulīśa-Pāśupatas. in: Goodall, Dominic \& André Padoux (eds.), Mélanges tantriques à la mémoire d'Hélène Brunner, Pondichéry. pp. 27-48.

2013 How to Behave like a Bull? New Insight into the Origin and Religious Practices of Pāśupatas. in: IIJ 56 (2013), 101-131.

Ackermann, Hans Christoph

1975 Narrative Stone Reliefs from Gandhāra in the Victoria and Albert Museum in London. Catalogue and Attempt at a Stylistic History. Rome. Reports and Memoirs XVII.

Adriaensen, $\mathrm{R}$ et al.

1994 See: Bakker, Hans \& R. Adriaensen \& H. Isaacson 1994.

Aerts, W.J. \& H. Hokwerda

2006 Leontios van Neapolis. Leven van Johannes de Barmhartige en Leven van Symeon de Heilige Dwaas. Ta Grammata, Groningen 2006.

Afghanistan

2008 Afghanistan, les trésors retrouvés. Collections nationales du musée de Kaboul, du 6 décembre 2006 au 30 avril 2007. U.S.A. exhibition: 'Afghanistan. Hidden treasure from the National Museum, Kabul', edit. by Fredrik Hiebert and Pierre Cambon. National Geographic Society, Washington 2008.

Agastyasaṃhitā

(AgS) Agastyasamhitā 1-23. Introduction, Critical Edition and Annotated Translation by Roelf Barkhuis. Thesis, Groningen 1995. 2 vols.

Agastyasaṃhitā. Edit. by Rāmnārāyaṇdās. Published by Seth Chotelal Laksmichand Bookseller Ayodhya. Printed at the Jain Press. Lucknow 1898.

Agni

1983 Agni. The Vedic Ritual of the Fire Altar. Edit. by Frits Staal. Berkeley 1983. 2 vols. 
Agrawal, Ashvini

1989 Rise and Fall of the Imperial Guptas. Delhi

1992 Did Kumāragupta I Abdicate? A study of the numismatic and epigraphic data. in: R.Ch. Chhabra et al. (eds.), Reappraising Gupta History for S.R. Goyal. New Delhi. pp. 165-172.

Agrawal, Jagannath

1986 Researches in Indian Epigraphy and Numismatics. Delhi.

Agrawala, Prithvi K.

1987 Observations on the Mundeshvari Temple. in: Rao, Nagaraja (ed.), Kusumāñjali. New Interpretation of Indian Art \& Culture. Sh.C.

Agrawala, R.C. Sivaramamurti Commemoration Volume. Vol. I. Delhi. pp. 179-83.

1987 Early Vaisnava Icons from Rajasthan. in: Parimoo, Ratan (ed.), Vaisnavism in Indian Arts and Culture. New Delhi. pp. 328-34.

Agrawala, Urmila

1964 Khajurāho Sculptures and their Significants. Delhi etc.

Agrawala, Vasudeva S.

1947-48 Terracotta Figurines of Ahichchhatrā, District Bareilly, U.P. in: Ancient India 4 (1947-48), 104-179.

1969 The Deeds of Harsha [being a cultural study of Bāna's Harshacharita]. Redacted and edited by P.K. Agrawala. Varanasi.

Ahmad, A.

1964 Studies in Islamic Culture in the Indian Environment. Oxford.

Aitareya Brāhmaṇa

(AB) Das Aitareya-Brāhmaṇa. Mit Auszügen aus dem Commentare von

Ajitāgama

Sāyanāāārya und anderen Beilagen. Hrsg. von Theodor Aufrecht. Bonn 1879.

Ali, Daud

2004

Edition critique par N.R. Bhatt. Pondichéry 1964-91. 3 vols. Publications de l'Institut Français d'Indologie 24.1-3.

Allan, John

1914 Catalogue of the Coins of the Gupta Dynasties and of Śaśānka, King of Gauda. The British Museum, London.

1936 Catalogue of the Coins of Ancient India. The British Museum, London.

Allchin, F.R.

1957 Sanskrit Edūka - Pāli Eluka. in: Bulletin of the School of Oriental and African Studies XX (1957), 1-4.

Altekar, Anant Sadashiv

1954 Catalogue of the Gupta Gold Coins in the Bayana Hoard. Bombay.

Altekar, A.S. \& R.C. Majumdar (eds.)

1960 The Vākāțaka-Gupta Age. (circa 200-550 A.D.). Bharatiya Itihas Parishad. New History of the Indian People Vol. 6.

Amarasimha

$\left(\mathrm{AK}_{1}\right) \quad$ Amarakośa with the unpublished South Indian Commentaries

Amarapadavivṛti of Lingayasūrin and the Amarapadapārijāta of Mallinātha. Critically edited with Introduction by A. A. Ramanathan. Vol. 1. Madras 1971. The Adyar Library Series 101.

$\left(\mathrm{AK}_{2}\right) \quad$ Pādacandrikā: a commentary on the Nāmalingānuśāsanam of Amara (Amarakośa), by Rāyamukuța, ed. Kali Kumar Dutta. Vol. III. (Calcutta Sanskrit College Research Series, no. CXXVI). Calcutta 1978. 
$\bar{A}$ nandavardhana

Dhvanyāloka, Uddyota 3, with Abhinavagupta's Locana and Rāmaśāraka's Bālapriyā. http://gretil.sub.uni-goettingen.de/gretil/1_sanskr/5_ poetry/1_alam/andhvc3u.htm. Input by members of the Sansknet project.

Andersen, Walter K. \& and Shridhar D. Damle

1987 The Brotherhood in Saffron. The Rashtriya Svayamsevak Sangh and Hindu Revivalism. Boulder/London.

Anguttaranikāya

The Anguttara-Nikāya. Vol. III edit. by E. Hardy. London $1897\left(1958^{2}\right)$. Pali Text Society.

Annual Administration Report

(AAR) Annual Administration Report of the Archæological Department Gwalior State for Vikram Samvat 1995, year 1938-39. Gwalior 1940.

Anquetil-Duperron, A.H.

1801-02 Theologica et Philosophia Indica. Oupnek'hat (Id est, Secretum Tegendum) ... Ad verbum, e Persico idiomate Sanskreticis vocabulis intermixto, in Latinum conversum, dissertationibus et annotationibus ... illustratum: studio et opera Anquetil du Perron. Strassburg/Paris. 2 vols.

Aparārka Yājñavalkyasmrtih [with the] Ṭīkā [of] Aparārka, [edit. by] Hari Nārāyana Āpte. [Poona] 1903-04. 2 vols. Ananda Ashrama Sanskrit Series 46.

$\bar{A}$ pastambadharmasūtra

(ĀpDhS) Āpastamba's Aphorisms on the Sacred Law of the Hindus. Edited in the original Sanskrit, with critical notes, variant readings from

Hiraṇyakeśi-dharmasūtras, an alphabetical index of sūtras, and word-index, together with extracts from Haradatta's commentary, the Ujjvalā, by George Bühler. Third Edition. Poona 1932. Bombay Sanskrit Series Nos. XLIV and L.

$\bar{A}$ pastambagṛhyasūtra

(ĀpGS) The Âpastambîya Grihyasûtra with extracts from the commentaries of Haradatta and Sudarśanārya. Edit. by M. Winternitz. Vienna 1887.

Āpastambaśrautasūtra

(Ā́S) The Śrauta Sūtra of Āpastamba belonging to the Taittirīya Saṃhitā with the commentary of Rudradatta. Edit. by Richard Garbe. With new appendix containing corrections and emendations to the text by C.G. Kashikar. Delhi 1983 (second ed.). 3 vols.

(tr. Caland) Das Śrautasūtra des Āpastamba aus dem Sanskrit übersetzt von W. Caland. 1. - 7. Buch, Göttingen/Leipzig 1921. 8. - 15. Buch, Amsterdam 1924.

Verhandelingen der Koninklijke Akademie van Wetenschappen, Afd.

Letterkunde NR, Deel XXIV, No. 1. 16. - 31. Buch, Amsterdam 1928.

Verhandelingen der Koninklijke Akademie van Wetenschappen, Afd.

Letterkunde NR, Deel XXVI, No. 4.

Apte, Prabhakar \& Shreenivas G. Supekar

1984 Vāstupurușamaṇuala in the Pauṣkarasaṃhitāand Bṛhatsaṃhitā. in: Agama and Silpa. Bombay 1984. pp. 132-148.

Archaeological Survey of India

(ASI) Archaeological Survey of India. Reports by Alexander Cunningham and others. Simla I871-Calcutta 1887, 23 vols.

Archaeological Survey of Western India, Vol. III. Report on the Antiquities in the Bidar and Aurangabad Districts, in the territories of His Highness the Nizam of Haidarabad, being the result of the third season's operations of the Archaeological Survey of Western India $1875-76$ by James Burgess. London 1878.

(ASI AR) Annual Report 1903-04. 
Archer, Mildred

1969 British Drawings in the India Office Library. London. 2 vols.

1980 Early Views of India. The Pituresque Journeys of Thomas and William Daniell 1786-1794. The Complete Aquatints. London.

Aristoteles

Aristotle's Metaphysics. A revised text with introduction and commentary by W.D. Ross. Oxford 1924. 2 vols.

Metaphysica by W.D. Ross. The Works of Aristotle translated into English under the editorship of J.A. Smith. Volume VIII. Oxford 1908.

Arthaśāstra

(AŚ) The Kauțilìya Arthaśāstra. A critical edition with glossary, an English translation with critical and explanatory notes, and a study by R.P. Kangle. Bombay 1963-65. 3 vols.

Asher, Frederick M.

1985 Eastern Indian Inscriptions: The problem of Era. in: Asher, F.M. \& G.S. Gai (eds.), Indian Epigraphy. Its bearing on the History of Art. New Delhi 1985, $133-37$.

Asiatic Researches

Asiatick Researches or Transactions of the Society [the Asiatic Society of Bengal], instituted in Bengal for inquiring into the history and antiquities, the arts, sciences and literature of Asia. Vols. 1-20. Calcutta 1788-1839. (Reprint, Varanasi 1972. 2 vols.).

$\bar{A}$ śvalāyanagrhyasūtra

(ĀśvGS) Gṛhyasūtrāṇi. Indische Hausregeln. Sanskrit und Deutsch herausgegeben von Adolf Friedrich Stenzler. I. Âçvalâyana. Leipzig 1864-65. Abhandlungen der Deutschen Morgenländischen Gesellschaft III. Band No. 4, IV. Band No. 1.

Āśvalāyana Gṛhyasūtram. With Sanskrit Commentary of Nārāyaṇa, English Translation, Introduction and Index by Narendra Nath Sharma. Delhi 1976.

Ayachit, S.M.

1985 See Sindūragirimāhātmya (SM).

Bajpai, K.D.

1977-78 New Light on the Early Pāṇdava Dynasty of South Kosala. in: ABORI LVIII-LIX (1977-78), 'Diamond Jubilee Volume', edit. by R.N. Dandekar, 434-437.

1992 Coins from Eran Excavations: A Chronological Analysis. in: Macdowall, D.W. et al. (eds.), Indian Numismatics, History, Art, and Culture. Essays in the Honour of Dr P.L. Gupta. Delhi.

Bajpai, K.D. \& S.K. Pandey

1977 Malhar 1975-1977(8). Sagar.

Bakker, Hans T.

works marked by * have been included in the present volume, article $[x]$

1982a The Rise of Ayodhyā as a Place of Pilgrimage. in: Indo-Iranian Journal (IIJ) 24 (1982), 103-126.

1982b On the Origin of the Sāmkhya Psychology. in: Wiener Zeitschrift für die Kunde Süd- und Ostasiens 26 (1982), 117-148.

1986 Ayodhyā. Pt. I The History of Ayodhyā from the 7th century BC to the middle of the 18th century. Its development into a sacred centre with special reference to the Ayodhyāmāhātmya and the worship of Rāma according to the Agastyasaṃitā. Pt. II Ayodhyāmāhātmya. Introduction, Edition, and Annotation. Pt. III Appendices, Concordances, Bibliography, Indexes, and Maps. Groningen. Groningen Oriental Studies I.

*1986b Ayodhyā: le nom et le lieu. in: Revue de l'Histoire des Religions CCIII/1, 53-66. [3] 
1987 Reflections on the Evolution of Rāma Devotion in the Light of Textual and Archaeological Evidence. in: Wiener Zeitschrift für die Kunde Südasiens Bd. XXXI (1987), 9-42.

1988 De Culturele Ontdekking van India. Romantische Geestdrift en de Opkomst der Oriëntalistiek. in: Bakker \& Gosman (eds.) 1988, pp. 94-112.

*1989a Some Methodological Considerations with Respect to the Critical Edition of Purāṇic Literature. in: XxIII. Deutscher Orientalistentag vom 16. bis 20. September 1985 in Würzburg. Ausgewählte Vorträge hrsg. von Einar von Schuler. Stuttgart. pp. 329-341. [9]

*1989b The Ramtek Inscriptions. in: Bulletin of the School of Oriental and African Studies vol.LII.3, 467-496. (= RI) [5]

1989c The Antiquities of Ramtek Hill (Maharashtra). in: Journal of South Asian Studies 5, 79-102.

1990 The History of Sacred Places in India as reflected in Traditional Literature. Papers on Pilgrimage in South Asia, edit. by Hans Bakker. Leiden. Panels of the VIIth World Sanskrit Conference vol. III.

*1990a An Indian Image of Man. An Inquiry into a Change of Perspective in the Hindu World-view. in: H.G. Kippenberg, H.G., Yme B. Kuiper \& Andy F. Sanders (eds.), Concepts of Persons in Religion and Thought. Berlin/New York. pp. 279-307. [1]

1990b Ramtek: An Ancient Centre of Viṣṇu Devotion in Maharashtra. in: Bakker 1990, 62-85.

1990c The History of Hanuman Worship in Ayodhyā. In: Lallanji Gopal \& D.P. Dubey (eds.), Pilgrimages Studies: Text and Context. Śr̄̄ Phalāhārī Bābā Commemoration Volume. Muirabad/Allahabad. pp. 127-135.

1991 The Footprints of the Lord. in: Diana L. Eck and Françoise Mallison (eds.), Devotion Divine. Bhakti Traditions from the Regions of India. Studies in Honour of Charlotte Vaudeville. Groningen Oriental Studies VIII. Groningen / Paris, pp. 19-38.

*1991a Ayodhyā: a Hindu Jerusalem. An investigation of 'Holy War' as a Religious Idea in the Light of Communal Unrest in India. in: Numen 38 (1991), 80-109. [4]

1992a The Sacred Centre as the Focus of Political Interest. Proceedings of the symposium held on the occasion of the 375th anniversary of the University of Groningen, 5-8 March 1989. Groningen. Groningen Oriental Studies VI.

1992b Memorials, Temples, Gods, and Kings. An attempt to unravel the symbolic texture of Vākāțaka kingship. in: A.W. van den Hoek, D.H.A. Kolff, M.S. Oort (eds.), Ritual, State and History in South Asia. Essays in Honour of J.C. Heesterman. Leiden. pp. 7-19.

1992c The Manbhaus' seat on Ramtek Hill. in: McGregor, R.S. (ed.), Devotional literature in South Asia. Cambridge 1992. pp. 11-25.

*1992d Throne and Temple. Political Power and Religious Prestige in Vidarbha. in: Bakker, Hans (ed.), The Sacred Centre as the Focus of Political Interest. Groningen. pp. 83-100. [7]

1993a Early Mythology Relating to Vārānasī. in: Rana P.B. Singh (ed.), Banāras (Vārānạas̄). Cosmic Order, Sacred City and Hindu Traditions. Festschrift to Prof R.L. Singh. Varanasi 1993. pp. 21-28.

1993b A Newly Found Statue from Nagardhan. in: South Asian Archæology 1991. Stuttgart. pp. 303-311.

*1994a Die Indische Herausforderung. Hegels Beitrag zu einer europäischen kulturhistorischen Diskussion. in: Bakker, H, J. Schickel \& B. Nagel (eds.), Indische Philosophie und europäische Rezeption. J. Dinter Verlag, Köln [1994]. Dialectica Minora 5. pp. 33-56. [2] 
*1994b Observations on the History and Culture of Dakșina Kosala (5th to 7th centuries AD). in: Nalini Balbir \& Joachim K. Bautze (eds.), Festschrift Klaus Bruhn, zur Vollendung des 65. Lebensjahres dargebracht von Schülern, Freunden und Kollegen. Reinbek 1994 (1995), pp. 1-66. [12]

*1996 Pārvatī's Svayamvara. Studies in the Skandapurāṇa I. in: Wiener Zeitschrift für die Kunde Südasiens 40 (1996), 5-43. [10]

1996a Construction and Reconstruction of Sacred Space in Vārānasā̄. in: Numen 43 (1996): 32-55.

1997 The Vākāțakas. An Essay in Hindu Iconology. Groningen. Gonda Indological Studies 5 .

1999 [Review article of:] Doris Meth Srinivasan, 'Many Heads, Arms and Eyes'. in: Artibus Asiae 58 3/4 (1999), 339-43.

*2000 Somaśarman, Somavamá and Somasiddhānta. A Pāśupata tradition in seventh-century Dakṣiṇa Kosala. Studies in the Skandapurāṇa III. in: Ryutaro Tsuchida and Albrecht Wezler (eds.), Harānandalaharī. Volume in Honour of Professor Minoru Hara on his Seventieth Birthday. Reinbek, pp. 1-19. [13]

2000a Tala Revisited. in: Maurizio Taddei \& Giuseppe De Marco (eds.), South Asian Archaeology 1997. Proceedings of the Fourteenth International Conference of the European Association of South Asian Archaeologist, held in the Istituto Italiano per l'Africa e l'Oriente, Palazzo Brancaccio, Rome, 7-14 July 1997 . Rome 2000 [= 2001]. Vol. III, pp. 1155-70.

*2000b Little Kr̦șna's Play with the Moon. in: Mariola Offredi (ed.), The Banyan Tree. Essays on Early Literature in New Indo-Aryan Languages (Proceedings of the Seventh International Conference on Early Literature in New-Indo-Aryan Languages, Venice 1997). New Delhi. 2 vols., II pp. 353-362. [8]

*2001 Sources for Reconstructing Ancient Forms of Śiva Worship. in: François Grimal (ed.), Les sources et le temps/Sources and Time. A colloquium, Pondicherry, 11-13 January 1997, Pondichéry 2001. pp. 397-412. [25]

2001a The Archaeological Site of Mansar. An Iconological Approach to Indian History: an Example. in: Torella, Raffaele (ed.), Le Parole e i Marmi. Studi in onore di Raniero Gnoli nel suo $70^{\circ}$ compleanno. Roma 2001 [=2002]. Serie Orientale Roma XCII. Vol. I, pp. 1-11.

2002 Religion and Politics in the Eastern Vākāṭaka Kingdom. in: South Asian Studies 18 (2002), 1-24.

2004a Mansar. in: Bakker, Hans T. (ed.), The Vākāṭaka Heritage. Indian Culture at the Crossroads. Groningen. pp. 71-85.

2004b Origin and Growth of the Purānic Text Corpus with Special Reference to the Skandapurāna. Papers of the 12th World Sanskrit Conference Vol. 3.2, edited by Hans T. Bakker. Delhi.

*2004c At the Right Side of the Teacher: Imagination, Imagery, and Image in Vedic and Śaiva Initiation. in: Granoff, Phyllis \& Koichi Shinohara (eds.), Images in Asian Religions. Toronto 2004. pp. 117-148. [26]

2004d The Vākātaka Heritage. Indian Culture at the Crossroads. Edited by Hans T. Bakker. Egbert Forsten, Groningen. Gonda Indological Studies XIII.

*2005 Commemorating the Dead. A note on Skandagupta's Bhitarī Inscription, vv. 8-12. in: Sharma, R.K. \& Devendra Handa (eds.), Revealing the Past: recent trends in art and archaeology. Prof. Ajay Mitra Shastri Commemoration Volume. Aryan Books, New Delhi. pp. 248-51. [18]

*2006 A Theatre of Broken Dreams. Vidiśā in the Days of Gupta Hegemony. in: Brandtner, Martin \& Shishir Kumar Panda (eds.), Interrogating History. Essays for Hermann Kulke, Chapter 9. New Delhi. pp. 165-187. [14] 
2006a The Avimuktakșetra in Vārāṇasī. Its Origin and Early Development. Studies in the Skandapurāna VI. in: Gaenszle, Martin \& Jörg Gengnagel (eds.), Visualizing Space in Banaras: Images, Maps, and the Practice of Representation. Wiesbaden. pp. 23-39.

*2007 Thanesar, the Pāśupata Order and the Skandapurāna. Studies in the Skandapurāṇa IX. in: Journal of Indological Studies 19 (2007), 1-16. [27]

*2007a Monuments to the Dead in Ancient North India. in: IIJ 50.1 (2007), 11-47. $[21]$

2007b Human Sacrifice (Purușamedha), Construction Sacrifice and the Origin of the Idea of the 'Man of the Homestead' (Vāstupuruṣa). in: Bremmer, Jan N. (ed.), The Strange World of Human Sacrifice. Leuven. pp. 179-194.

2007c The Hindu Religion and War. in: King, Anna S (ed.), Indian Religions. Renaissance and Renewal. The Spalding Papers in Indic Studies. London. pp. $28-40$.

2008 Mansar. The Discovery of Pravareśvara and Pravarapura, Temple and Residence of the Vākātaka King Pravarasena II. Proceedings of a Symposium at the British Museum, London, 30 June - 1 July, 2008. Library of the University of Groningen, Groningen. e-book: http://irs.ub.rug.nl/dbi/4ccec5f085aa0

2008a A Funerary Monument to Prabhāvatīguptā? in: Bautze-Picron, Claudine (ed.), Religion and Art: New Issues in Indian Iconography and Iconology. London 2008. pp. 81-91.

*2009a Purusamedha, Manasarapurusa, Vāstupurusa. The image of Man in the Sacrificial Context. in: Journal of Indological Studies 20 \& 21 (2008-09), 1-23. [22]

*2009b The So-called 'Jaunpur Stone Inscription of İ́varavarman'. in: IIJ 52.2-3 (2009), 207-216. [19]

*2009c Rāma Devotion in a Śaiva Holy Place: The Case of Vārānasī. Chapter 5 in: Pauwels, H.R.M. (ed.), Patronage and Popularisation, Pilgrimage and Procession. Channels of Transcultural Translation and Transmission in Early Modern South Asia. Papers in Honour of Monika Horstmann. Harrassowitz Verlag, Wiesbaden. pp. 67-80. [23]

*2010a La collina di Rāma. Transgressione ed espiazione su una collina nel sud e l'inadeguatezza delle sostituzioni [Rāma's Hill. Transgression and Atonement on a Hill in the South and the Inadequacy of Substitutes]. in: Pellizzari, Paolo (ed.), La bisaccia del pellegrino: fra evocazione e memoria, a cura di Amilcare Barbero e Stefano Piano. Atlas, Centro di Documentazione dei Sacri Monti, Monferrato. pp. 73a'--82. [16] (English)

2010b Rohitāgiri. in: Caracchi, Pinuccia et al. (eds.), Tìrthayātrā. Essays in Honour of Stefano Piano. Edizioni dell'Orso, Alessandria. pp. 15-26.

*2010c Trivikrama: Word and Statue. A new interpretation of Rāmagiri evidence (1). in: Acta Orientalia Academiae Scientiarum Hungaricae. Volume 63.3 (2010), 241-247. DOI: 10.1556/AOrient.63.2010.3.1 [17.1]

*2010d Royal Patronage and Religious Tolerance. The Formative Period of Gupta-Vākātaka Culture. in: Journal of the Royal Asiatic Society 20.4 (2010), 461-75. [15]

*2010e The Hindu Religion and War. in: Dijk, Jacobus van (ed.), Onder Orchideeën. Nieuwe Oogst uit de Tuin der Geesteswetenschappen te Groningen. Barkhuis Publishing, Groningen. pp. 7-17. [2nd edition of the 2007 publication]. [24]

*2010f The Gospel of Kaundinya: The Descent of God in Gujarat and the Practice of Imitating God. in: Dijkstra, Jitse, Justin Kroesen \& Yme Kuiper (eds.), Myths, Martyrs, and Modernity. Studies in the History of Religions in Honour 
of Jan N. Bremmer. Brill, Leiden 2010, pp. 517-29. Numen Book Series 127. [28]

*2011 Origin and Spread of the Pāśupata Movement. About Heracles, Lakulīśa and Symbols of Masculinity. in: Tikkanen, Bertil \& Albion M. Butters (eds.), 'Pūrvāparaprajñābhinandanam', East and West, Past and Present: Indological and Other Essays in Honour of Klaus Karttunen. Helsinki. Studia Orientalia 110. pp. 21-37. [29]

*2012 The Gupta-Vākāṭaka Relationship. A new interpretation of Rāmagiri evidence (2). in: Religions of South Asia 5.1-2 (2011), 293-302. DOI: $10.1558 /$ rosa.v5i1/2.293 . [17.2]

*2013a The Temple of Manḍleśvarasvāmin. The Mundeśvarī Inscription of the Time of Udayasena Reconsidered. in: Bosma, N. \& Nina Mirnig (eds.), IIJ 56.3-4 (2013), 263-277. [20]

*2013b The Trivikrama Temple: A New Interpretation of Rāmagiri evidence (3). in: South Asian Studies 29.2 (2013), 169-76. [17.3]

*2013c Composition and Spread of the Skandapurāna. An Artist's Impression.

Concluding Lecture of VVIK Indologendag 2013: 'The Study of the History of Hinduism in the Sanskrit Tradition.' Leiden, https://instituutkern.nl/content/uploads/mediabank/bakker_symposium_ bakker_lecture_28_sept_2013.pdf. [31]

2014 The World of the Skandapurāna. Northern India in the Sixth and Seventh Centuries. Brill, Leiden/Boston. Supplement to Groningen Oriental Studies.

2018 [Review article of] Dominic Goodall et al. (eds.), 'The Niśvāsatattvasaṃhitā'. Pondichéry/Hamburg 2015. in: IIJ 61.3 (2018), 263-71.

Bakker, Hans \& R. Adriaensen \& H. Isaacson

1994 Towards a Critical Edition of the Skandapurāna. in: IIJ 37 (1994), 325-331.

Bakker, Hans \& Peter Bisschop

*1999 Mokșadharma 187 and 239-241 Reconsidered. in: Asiatische Studien/Études Asiatiques LII.3 (1999), 459-472. (= Proceedings of the 'Conference Sāmkhya and Yoga', Université de Lausanne, November 6-8 1998). [11]

*2016 The quest for the Pāśupata Weapon: the Gateway of the Mahādeva Temple at Madhyamikā (Nagarī). in: IIJ 59 (2016): 217-258. [30]

Bakker, Hans \& Alan Entwistle

1981 Vaișnavism. The history of the Krșna and Rāma cults and their contribution to Indian pilgrimage. Groningen.

1983 Devī. The worship of the Goddess and its contribution to Indian pilgrimage. Groningen.

Bakker, Hans \& Harunaga Isaacson

*1993 The Ramtek Inscriptions II. The Vākātaka Inscription in the

Kevala-Narasimha Temple. in: Bulletin of the School of Oriental and African Studies LVI (1993), 46-74. [6]

Bakker, Hans \& Martin Gosman (eds.)

1988 De Oriënt, Droom of Dreiging? Het Oosten in Westers Perspectief. Kampen.

1991 Heilige Oorlogen. Een onderzoek naar historische en hedendaagse vormen van collectief religieus geweld. Kampen.

Balogh, Dániel

Miregāon Plates of Prabhāvatiguptā. in: Siddham, the South Asian

Inscriptions Database http://siddham.uk/inscription/IN00185.

forthc. Bhitari Stone Pillar Inscription of Skandagupta. in: Siddham, the South Asian Inscriptions Database http://siddham.uk/inscription/.

Bāna

(HC) The Harșacarita of Bānabhatța (Text of Ucchvāsa I-VIII). Edit. with an Introduction and Notes by P.V. Kane. Delhi etc. 1965 (2nd ed.). 
(HC*) Harșacaritam, śrī-Śaṅkaraviracita 'Sañketa' vyākhyopetam.

Hindīvyākhyākārah śrī Jagannātha Pāṭhakaḥ. Caukhambā Vidyābhavan, Vārānasīi 1958.

1897 The Harșa-carita of Bāna translated by E.B. Cowell and F.W. Thomas. London. Oriental Translation Fund New Series II.

Banerjea, Jitendra Nath

1935 The Phallic Emblem in Ancient and Medieval India. in: Journal of the Indian Society of Oriental Art 3 (1935), 36-44.

1956 The Development of Hindu Iconography. Delhi.

Banerji, R.D.

1907-08 Mundesvari Inscription of Udayasena. The [Harsha] Year 30. in: EI IX (1907-08), $289 \mathrm{f}$.

Barnett, Richard B.

1980 North India Between Empires. Awadh, the Mughals, and the British 1720-1801. Berkeley/Los Angeles/London.

Barthwal, P.D.

1978 Traditions of Indian Mysticism based upon Nirguna School of Hindi Poetry. New Delhi.

Bareau,André

1979 Ayodhyā et Mithilā dans les textes canoniques du Bouddhisme ancien. in: Indologica Taurinensia VII (1979), 75-82.

Basham, A.L.

1967 The Wonder that was India. Third revised edition, London.

Baudhāyanagṛhyasūtra

(BauGS) The Bodhâyana Grihyasūtra edit. by R. Shama Sastri. Mysore 1920.

University of Mysore, Oriental Library Publications, Sanskrit Series 32/55.

Baudhāyanaśrautasūtra

(BŚS) Baudhāyana Śrautasūtra [X] on the Agnicayana. Text by W. Caland, translation by Yasuke Ikari and Harold F. Arnold. in: Agni II, 478-675.

Beal, Samuel

$$
\text { See Xuanzang }
$$

Bedekar, V.M.

1969 Principles of Mahābhārata textual criticism: The need for restatement. in:

Purāṇa XI No. 2 (1969), 212-228.

Bemmann, Martin \& Ditte König

1994 Die Felsbildstation Oshibat. Mainz. Materialien zur Archäologie der Nordgebiete Pakistans I.

Bernard, Paul

2008 The Greek Colony at Aï Khanum and Hellenism in Central Asia. in: Afghanistan 2008, 81-129.

Bhadrabāhu

The Kalpasūtra of Bhadrabāhu, edit. with an Intr., Notes, and a Prakrit-Samskrit glossary by Hermann Jacobi. Leipzig 1879 (Nachdruck Nendeln, 1966). Abh. für die Kunde des Morgenlandes 7.1.

Bhagavadgìtā

(BhG) The Bhagavadgītā being reprint of relevant parts of Bhịṣmaparvan from B.O.R. Institute's edition of the Mahābhārata. For the tirst time critically edited by Sh.K. Belvalkar. Poona 1945.

(Ed. princeps) Śr̄mmad Bhagavadgītā (Editio Princeps in Devanāgarī) edited by Brāhman Bābū Rāma, under Colebrooke's auspices, Bābūrāma Press, Khidaspoor/Calcutta. Śaka samvat 1730 (= AD 1808/09).

The Bhâgvât-Geetâ, or Dialogues of Krêêshna and Ârjôôn in eighteen lectures. With notes translated from the original Sanskrêêt, or ancient language of the Brâhmâns, by Ch. Wilkins. London 1785 . 
La Bhaguat-Geeta, ou Dialogues of de Kreeshna et d'Arjoon, contenant un précis de la religion et de la morale des lndiens, traduit du Sanscrit, la langue sacrée des Brahmes, en anglois par M. C. Wilkins, et de l'Anglois en Français par Rev. M. Parraud. Paris 1787.

Aus dem Bhagavadgita. Von F. Mayer. in: Asiatischer Magazin (J. Klaproth). Weimar 1802 .

(BhG, tr.) The Bhagavad Gītā, translated and interpreted by Franklin Edgerton. Part I: text and Translation. Cambridge (Mass.) 1952. Harvard Oriental Studies 38.

Bhāgavatapurāṇa

(BhāgP) Śrīmad Bhāgavatapurāṇam. Śrīdharasvāmiviracitayā

Bhāvārthabodhin̄̄nāmnyā samskrtatīkayā samupetam. Edited by J.L.

Shastri. Motilal Banarsidass, Delhi, 1983.

Śrībhāgavatam [Śrīmad Bhāgavata Mahāpurāṇa]. Critical Edition by H.G.

Shastri et al. Volume I-IV. Bh.J. Institute of Learning and Research, Ahmedabad 1996-98. 4 vols.

Bhandarkar, D.R.

1906-07 Lakulīśa. in: Archaeological Survey of India. Annual Report 1906-07, 179-92.

1920 The Archæological Remains and Excavations at Nagari. in: Archæological Survey of India, Memoirs 4, pp. 117-141.

1931-32 Mathura Pillar Inscription of Candragupta II. in: Epigraphia Indica 21 (1931-32), 1-9.

Bhandarkar, Ramkrishna Gopal

1913 Vaiṣnavism, Śaivism and minor religious systems. Strassburg. Grundriss der Indo-Arischen Philologie und Altertumskunde (Encyclopedia of Indo-Aryan Research) III.6.

1928 Early History of the Dekkan: down to the Mahomedan conquest. Calcutta 1928 (3rd. ed.).

Bhāradvājagrhhyasūtra

(BhGS) Het Hindoesche Huisritueel volgens de School van Bhāradvāja. [Edit. by] Henriette Johanna Wilhelmina Salomons. Leiden 1913. Thesis.

Bhāratīya-Nātyaśāstra

The Nātyaśāstra ascribed to Bharata-muni, edited with an introduction and various readings by Manomohan Ghosh. Vol. I (Chapters I-XXVII). Revised second edition, Calcutta 1967.

Bhāravi

(KA) The Kirātārjunīya of Bhāravi with the commentary (Ghaṇtāpatha) of Mallinātha and various readings. Ed. Pandit Durgāprasād and Kāśn̄nāth Pāṇụrang Parab, revised by Wāsudev Laxmaṇ Śāstrī Paṇsíkar. Bombay 1933.

Bhargava, Manohar Lal

1964 The Geography of Rgvedic India (a Physical Geography of Sapta Saindhava). Lucknow.

Bhāsa

Bhāsanāṭakacakram. Plays ascribed to Bhāsa, crit. edit. by C. R. Devadhar. Poona 1962. Poona Oriental Series No. 54.

The Pratimānātakam of Bhāsa. Edit. with a short Sanskrit Commentary, English translation, and Critical Notes by M.R. Kale. Delhi etc. 1977. [reprint of the Bombay 1930 edition].

Bhatnagar, G.D.

1968 Awadh under Wājid ‘Al̄̄ Shāh. Benares.

Bhatt, N.R.

1984 Śaiva Āgamas. in: Agama and Silpa. Bombay 1984. pp. 10-28. 
Bhattacharya, Ahi Bhushan

1945 Benares Plates of Hari Rāja of Śūra Dynasty. in: The Journal of the United Provinces Historical Society 18 (1945), 167-73.

Bhattasali, Nalini Kanta

1929 Iconography of Buddhist and Brahmanical Sculptures in the Dacca Museum. Dacca.

Biardeau, Madeleine

1968 Some more considerations about textual criticism. in: Purāṇa X No. 2 (1968), $115-123$.

1970 The story of Arjuna Kārtavīrya without reconstruction. in: Purāṇa XII No. 2 (1970), 286-303.

2002 Le Mahābhārata. Un récit fondateur du brahmanisme et son interprétation. Paris. 2 vols.

Bisschop, Peter

2002 On a quotation of the Skandapurāna in the Tìrthavivecanakānda of Lakșmīdhara's Krtyakalpataru. Studies in the Skandapurāna V. in: IIJ 45 (2002), pp. 231-243.

2006 Early Śaivism and the Skandapurāna. Sects and Centres. Groningen. Groningen Oriental Studies XXI.

2006a The Sūtrapāṭ̂a of the Pāśupatasūtra. in: IIJ 49 (2006), 1-21.

Bisschop, Peter \& Arlo Griffiths

2003 The Pāśupata Observance (Atharvavedapariśista 40). in: IIJ 46 (2003), $315-48$.

Bloch, T.

1902-03 The Temple of Muṇ̣eśvarī. in: ASI Annual Report 1902-03, $42 \mathrm{f}$.

1906 Excavations at Basarh. in: Archaeological Survey of India, Annual Report (ASIAR) 1903-04. Calcutta 1906, 81-122.

1906-07 Excavations at Lauriya. in: ASI, Annual report 1906-07, 119-126.

Bock, Andreas

1984 Der Sāgara-Gangāatatarana-Mythos in der episch-purānischen Literatur. Stuttgart. Alt- und Neu-Indische Studien 27.

Bodewitz, Henk W.

1977-78 Atharvaveda Samphitā 3, 12: the Building of a House. in: Annals of the BORI LVIII and LIX (1977-78) (= Diamond Jubilee Volume edit. by R.N. Dandekar), 59-68.

1999 Hindu Ahimsā and its Roots. in: Houben, Jan E.M. \& Karel R. van Kooij (eds.), Violence Denied. Violence, Non-Violence and the Rationalization of Violence in South Asian Cultural History. Leiden etc. 1999. pp. 17-41.

2000 Classifications and Yonder World in the Veda. in: WZKSA 44 (2000), 19-59.

Bombay Gazetteer

1896 Gazetteer of the Bombay Presidency. Under Government Orders. Vol. 1. Bombay.

Bonazzoli, Giorgio

1983 Composition, transmission and recitation of the Purānas (A Few Remarks). in: Purāṇa XXV No. 2 (1983), 254-80.

1984 The Pretakalpa of the Garudapurāna (Adhyāya 5). Critically edited by Giorgio Bonazzoli. Varanasi.

Boner, Alice \& Sadāśiva Rath Śarmā (eds.)

1966 Śilpa Prakāśa. Medieval Orissan Sanskrit Text on Temple Architecture by Rāmacandra Kaulācāra. Translated and annotated by - -. Leiden. 
Bopp, Franz

1816 Franz Bopp über das Conjugationssystem der Sanskrit Sprache in Vergleichung mit jenem der griechischen lateinischen, persischen und germanischen Sprache. Nebst Episoden des Ramajan und Mahabharat in genauer metrischen Uebersetzungen ... und einigen Abschnitten aus den Veda's. Herausgegeben und mit Vorerinnerungen begleitet von Dr. K.J.

Windischmann. Frankfurt.

Bosch, L.P. van den

1990 Levende Godsdiensten 1. Deelmodule: Inleiding in het hindoeisme. Kampen. Open Theologisch Onderwijs. Groep V: Theologie en Dialoog.

Bose, Nirmal Kumar

1932 Canons of Orissan Architecture. Calcutta.

Bosma, Natasja

2018 Dakșiṇa Kosala. A Rich centre of Early Śaivism. Barkhuis, Groningen.

Bouchart, François-Xavier

1982 Marcel Proust. La Figure des Pays. Paris.

Bowering, G.

1980 The Mystical Vision of Existence in Classical Islam. The Chur’ānic

Hermeneutics of the Sūfī Sahl Al-Tustarī (d. 283/896). Berlin/New York.

Studien zur Sprache, Geschichte und Kultur des Islamischen Orients, Neue

Folge Bd. 9 .

Bowra, C.M.

1952 Heroic Poetry. London.

Brahmāṇ̣apurāṇa

(BḍP) Śrī-Vyāsa-maharșiproktam Brahmāṇḍapurāṇam. (With Introduction in

Sanskrit and English and an Alphabetical Index of Verses). Edit. by J. L.

Shastri. Delhi etc. 1973. (Reprint of the Venkatesvara edition of AD 1912).

Brahmapurāṇa

(BrP) Vol. 1, Sanskrit Indices and text of the Brahmapurāna by Peter Schreiner and Renate Söhnen. Vol. 2, Brahmapurāṇa. Summary of Contents, with Index of Names and Motifs by Renate Söhnen and Peter Schreiner. Wiesbaden. 2 vols. Purāṇa Research Publications, Tübingen 1 and 2.

Brandtner, Martin

1994 Bibliographie zum Konflikt um Ayodhya und seinem Umfeld. in:

Internationales Asienforum 25 (1994), 383-390.

Bremmer, Jan N.

2007 The Strange World of Human Sacrifice. Leuven.

Bṛhadbrahmasamhitā

The Bṛhadbrahmasaṃhitā, edit. by H.A. Apte. Poona 1912. Ānanda Āśrama

Sanskrit Series No. 68.

Brhatsūcīpatram

[Index of Old Mss in the National Archives, Nepal] Vol. 8 Purāṇa and Itihāsa

by Bābu Krṣna Śarmạ [under the supervision of] Buddhisāgara Śarman.

Publication of the National Archives, Kathmandu s.d. Purātatva Prakaśana

Series 43.

Briggs, G.W.

1938 Gorakhnāth and the Kānphața Yogīs. Calcutta.

Brinkhaus, Horst

1983 Zur Paraśurāma-Monographie von Adalbert Gail. in: WZKSA XXVII (1983), 43-63.

Brodersen, Kai

1991 Heilige Oorlog en Heilige Vrede in de vroeg-Griekse Geschiedenis. in: Bakker \& Gosman 1991, pp. 39-51.

Brown, Percy

1976 Indian architecture (Buddhist and Hindu periods). Bombay. 
Bryant, Kenneth E.

1978 Poems of the Child-God. Structures and Strategies in the Poetry of Sūrdās. Berkeley/Los Angeles/London.

Buckee, Fiona

forthc. The Curious Case of the Octagonal Temple: A Revised History of the Temples of Mundeshvari Hill. Paper presented at the 24th Conference of the European Association for South Asian Archaeology and Art (EASAA) in Naples, 2-6 July 2018.

Bühler, G.

1896 Indische Palaeography. Von circa 350 A. Chr. - circa 1300 P. Chr. Strassbourg. Grundriss der Indo-Arischen Philologie und Altertumskunde, I. Bd., 11. Ht.

Bühnemann, Gudrun

2007 śivalingas and caityas in representations of the eight cremation grounds from Nepal. in: Kellner, Birgit, Helmut Krasser \& Horst Lasic et al. (eds.), Pramānakīrtih. Papers dedicated to Ernst Steinkellner on the occasion of his 70th birthday. Vienna. 2 vols. Vol. I, 23-36.

Buitenen, J.A.B. van

1956 Studies in Sāṃkhya I. in: Journal of the American Oriental Society 76 (1956), 153-157 [=Studies in Indian Literature and Philosophy, Delhi 1988, 43-52].

1957a Studies in Sāṃkhy II. in: Journal of the American Oriental Society 77 (1957), 15-25 [=Studies in Indian Literature and Philosophy, Delhi 1988, 53-74].

1957b Studies in Sāmkhya III. in: Journal of the American Oriental Society 77 (1957), 88-107 [=Studies in Indian Literature and Philosophy, Delhi 1988, 75-110].

Bulke, Ph. K.

1971 Rāmkathā (Utpatti aur Vikas). Prayaga $1971^{3}$.

Burghart, R.

1983 Renunciation in the Religious Traditions of South Asia. in: Man (N.S.) 18 (1983), 635-53.

Burkert, W.

1986 Krieg, Sieg und die Olympischen Götter der Griechen. In: Stolz 1986, pp. 67-87.

Burn, R.

1906 Some Coins of the Maukharis, and of the Thanesar Line. in: JRAS (1906), 843-50.

Caland, W.

1896 Die altindischen Todten- und Bestattungsgebräuche. Mit Benutzung handschriftelicher Quellen. Amsterdam. Verhandelingen der KNAW Afd. Lett. Deel I. No. 6.

1912 De archæologische vondsten in de heuvels van Lauriya. in: Verslagen en Mededelingen der Koninklijke Akademie van Wetenschappen (Afd. Lett.), vierde reeks, elfde deel, pp. 378-385.

Callewaert, Wim \& S. Hemraj

1982 Bhagavadgītānuvāda. A study in transcultural translation. Ranchi.

Cannon, Garland

1979 Sir William Jones. A Bibliography of primary and secondary sources. Amsterdam. Amsterdam Studies in the Theory and History of Linguistic Science Series V. Library and Information Sources in Linguistics vol. 7.

Carnegy, P.

1870 A Historical Sketch of tahsil Fyzabad, zillah Fyzabad, including parganas Haveli-Oudh and Pechhimrath, with the old capitals Ajudhia and Fyzabad. Lucknow. 
Cecil, Elizabeth Ann

2016 Mapping the Pāśupata Landscape. The Skandapurāna, Lakulīśa, and the Saiva Imaginary in Early Medieval North India (6th-10th Century CE). Brown University, Providence (thesis).

Chakravarty, Kalyan Kumar

1992 The Temples at Tala and the Art of Dakșina Kośala. Harvard University, Cambridge (MA). [Unpublished PhD thesis].

2018 Walking with Śiva. Cognitive roots of Indian art, archaeology and religion, with reference to Tala and Dakșiṇa Kosala. Aryan Books, New Delhi. 2 vols.

Chaudhuri, Nirod C.

1980 Hinduism. A religion to live by. Oxford.

Chhabra, B. Ch.

1949 Ten Years of Indian Epigraphy (1937-46). in: Ancient India 5 (1949), 47-48, Plates XXI-XXII.

1963 Some Observations on the Bhitari Inscription of Skandagupta. in: Journal of Indian History XLI (1963), 543-49.

Clark, Matthew

2006 The Daśanāmī-Samnyāsīs. The Integration of Ascetic Lineages into an Order. Brill, Leiden-Boston. Brill's Indological Library 23.

Cœedès, George

1937-66 Inscriptions du Cambodge. 8 vols. Paris: EFEO 1937 (vol. 1), 1942 (vol. 2), 1951 (vol. 3), 1952 (vol. 4), 1953 (vol. 5), 1954 (vol. 6), 1964 (vol. 7), 1966 (vol. 8). [K $=$ Khmer inscription, numbered as in Coedès 1937-66].

1940 Études Cambodgiennes. XXXIII. — La destination funéraire des grands monuments Khmèrs. in: Bulletin de l'EFEO XL (1940), 315-349.

Cohen, Richard S.

1998 Nāga, Yakșiṇ̄ , Buddha. Local deities and local Buddhism at Ajanta. in: History of Religions 37 (1998), 360-400.

Colas, Gérard

2004 The Competing Hermeneutics of Image Worship in Hinduism (Fifth to Eleventh century AD). in: Granoff, Phyllis \& Koichi Shinohara (eds.), Images in Asian Religions. Toronto 2004. pp. 149-179.

Colebrooke, Henry Thomas

1808 On the Védas or sacred writings of the Hindus. in: Asiatic Researches VIII (1808), 377-497.

1824 On the Philosophy of the Hindus. Pt. I \& Pt. II. in: Transactions of the Royal Asiatic Society of Gr. Britain and Ireland Vol. 1 (1824), 19-43, 92-118.

Colpe, Carsten

1984 Zur Bezeichnung und Bezeugung des 'Heiligen Krieges'. in: Berliner

Theologische Zeitschrift 1 (1984), 45-57, 189-214.

Comparative Dictionary of the Indo-Aryan Languages

(CDIAL) See Turner 1966.

Corpus Inscriptionum Indicarum

(CII I) Inscriptions of Aśoka by E. Hultzsch. Corpus Inscriptionum Indicarum Vol. I. ASI, Oxford 1925. Reprinted, New Delhi 1991.

(CII II A) Kharoshthī Inscriptions with the exception of those of Aśoka edited by Sten Konow. Reprint, Delhi 1991. Corpus Inscriptionum Indicarum Vol. II, Part I.

( CII II B) Barhut Inscriptions edit. by H. Lüders. Revised by E. Waldschmidt and M.A. Mehendale. Reprint, Delhi 1998. Corpus Inscriptionum Indicarum Vol. II, Part II.

(CII III (1888)) Inscriptions of the Early Gupta Kings and their Successors. Edit. by J.F. Fleet, Calcutta 1888. 
(CII III (1981)) Inscriptions of the Early Gupta Kings. Revised by Devadatta Ramakrishna Bhandarkar. Edit. by Bahadurchand Chhabra \& Govind Swamirao Gai. New Delhi 1981.

(CII IV) Inscriptions of the Kalacuri-Chedi Era. Edited by V.V. Mirashi. Ootacamund 1955. 2 vols. Archaeological Survey of India.

(CII V) Inscriptions of the Vākāțakas. Edited by V.V. Mirashi. Ootacamund 1963. Archaeological Survey of India.

Cousens, Henry

1931 Mediaeval temples of the Dakhan. Calcutta.

Creuzer, Friedrich G.

1810-23 Symbolik und Mythologie der alten Völker, besonders der Griechen. Leipzig/Darmstadt. 6 vols.

Crollius, A.R.

1978 Die islamische Transzendenzerfahrung im indischen Kontext. Zur Beziehung zwischen Sufismus und Bhakti. in: Oberhammer, Gerhard (ed.), Tranzendenzerfahrung, Vollzugshorizont des Heils. Wien. pp. 81-96.

Crooke, William

1906 Things Indian, being discursive notes on various subjects connected with India. London. (Reprint Delhi 1972).

1926 The Popular Religion and Folk-lore of Northern India. Oxford. 2 Vols.

Cult of Jagannāth

(COJ) See Eschmann et al. 1978.

Cunningham, Alexander

((ASI) See: Archaeological Survey of India.

Curschmann, Michael

1967 Oral Poetry in Medieval English, French, and German Literature. Some notes on recent research. in: Speculum 42 (1967), 36-52.

Dagens, Bruno

1984 Entre Alampur et Śrīśailam. Recherches archéologiques en Andhra Pradesh.

Tôme I Texte. Tôme II Illustrations. Pondichéry. Publications de l'Institut

Français d'Indologie 67.1-2.

Dalal, Chimanlal D

1920 Ganakārikā of Ācārya Bhāsarvajña. With four appendices including the Kāravaṇa-Māhātmya. Edit. by Ch. D. Dalal. Baroda (reprint 1966).

Gaekwad's Oriental Series No. 15.

Dani, Ahmad Hasan

1963 Indian palaeography. Oxford (2nd ed. 1986).

Daniélou, Alain

1989 Manimekhalaï, the Dancer with the Magic Bowl by Merchant-Prince Shattan.

Translated from the Tamil by Alain Daniélou; co-translator: Kenneth F.

Hurry; With the collaboration of T.V. Gopala Iyer. New York.

Das, D.R.

1968 Archaeological Evidence on Cremation and Post-Cremation Burial in India. in: Journal of Ancient Indian History III.1-2 (1968), 50-71.

Das Gupta, S.

1969 Obscure Religious Cults. Calcutta (3rd ed.).

Davis, Richard H.

1991 Ritual in an Oscillating Universe. Worshiping Śiva in Medieval India.

Princeton.

De, S.K.

1961 Early History of the Vaisnava Faith and Movement in Bengal from Sanskrit and Bengali sources. Calcutta (2nd ed.).

Deglurkar, G.B.

1974 Temple architecture and sculpture of Maharashtra. Nagpur. 
Deloche, Jean

1980 La circulation en Inde avant la révolution des transports. Tome 1: La voie de terre. Paris. Publications de l'École Française d'Extrême Orient CXXII.

de Marco, Giuseppe

1987 The Stūpa as a Funerary Monument. New Iconographical Evidence. in: East and West 37 (1987), 191-246.

Deo, S.B. \& M.K. Dhavalikar

1968 Paunar Excavation (1967). Nagpur.

Deppert, Joachim

1977 Rudras Geburt. Systematische Untersuchungen zum Inzest in der Mythologie der Brāhmanas. Wiesbaden. Beiträge zur Südasienforschung, Band 28.

Derrett, J.D.M.

1976 Rājadharma. in: Journal of Asian Studies XXXV (1976), 597-603.

Deshpande, Suresh Raghunath

1985 Yadava Sculpture (Western Maharashtra: 1000 A.D. to 1400 A.D.). Delhi.

De Simini, Florinda

2013 Ritual Aspects of Manuscript Transmission in Premodern India: a Historical Study of Vidyādāna through Textual Sources. With a First Critical Edition and English Translation of Sivadharmottara's Chapter Two 'On The Gift of Knowledge'. Università degli Studi di Torino (thesis).

Deva, Krishna

1988 Maukharis and Puṣpabhūtis of Kānyakubja. in: Meister, Michael W. et al. (eds.), Encyclopaedia of Indian Temple Architecture (EITA). North India. Foundations of North Indian Style c. 250 B.C.-A.D. 1100. Vol. II.1. Delhi 1988.

Dey, Nundo Lal

The Geographical Dictionary of Ancient and Mediæval India. New Delhi 1971 (reprint of the 1927 edition).

Dhaky, M.A.

1984 Bhūtas and Bhūtanāyakas: Elementals and their Captains. in: Meister, M.W. (ed.), Discourses on Śiva. Bombay. pp. 240-256.

Dikshit, Moreshwar G.

1960 Sirpur and Rajim Temples. Bombay.

Dīptāgama

Édition critique. Marie-Luce Barazer-Billoret, Bruno Dagens et Vincent Lefèvre, avec la collaboration de S. Sambhandha Śivācārya. Institut Français de Pondichéry, Pondichéry 2004-09. 3 vols. Collection Indologie 81.1-3.

Dirks, Nicolas B.

1976 Political Authority and Structural Change in Early South Indian History. in: Indian Economic and Social History Review 13 (1976), 125-57.

Divyāvadāna

The Divyâvadâna. A Collection of Early Buddhist Legends. Sanskrit text in transcription, edited from the Nepalese manuscripts in Cambridge and Paris [by] Edward B. Cowell \& Robert A. Neil. Cambridge 1886 (reprint, Amsterdam 1970).

Donaldson, Thomas E.

1985-87 Hindu Temple Art of Orissa. Leiden. 3 vols. Studies in South Asian Culture.

1986 Bhikṣāṭanamūrti Images from Orissa. in: Artibus Asiae 47 (1986), 51-66.

Dumarçay, Jacques \& Françoise l'Hernault

1975 Temples Palava Construits. Étude architecturale par J. Dumarçay. Étude iconographique par F. l'Hernault. Paris. Publications de l'École Française d'Extrême-Orient. Mémoirs Archéologiques IX.

Dumont, L.

1966 Homo Hierarchicus. Essai sur le système des castes. Paris. 
Dutt, Manmatha Natha (ed.)

1988 The Dharma-Śāstra or the Hindus Law Codes. Text. Yājñavalkya, Hārīta, Uśanas, Añgiras, Yama, Atri, Samivarta, Kātyāyana, Bṛhaspati, Dakșa, Śātātapa, Likhita, Śamkhya, Gautama, Āpastamba, Vaśișțha. Vol. I edited by - -. Delhi.

Dviveda, Vraja Vallabha

1982 Purānavarnitāh Pāśupatā yogācāryāh. in: Purāna XXIV.2 (1982), Samskṛta-khaṇda pp. 1-21.

Eaton, R.M.

1978 Sufis of Bijapur 1300-1700. Social Roles of Sufis in Medieval India. Princeton.

Eck, D.L.

1991 Following Rāma, worshipping Śiva. in: D.L. Eck \& F. Mallison (eds.),

Devotion Divine. Groningen/Paris 1991. Groningen Oriental Studies VIII.

Edgerton, Franklin

1965 The Beginnings of Indian Philosophy: selections from the Rig Veda, Atharva

Veda, Upanișads, and Mahābhārata, translated from the Sanskrit with an introduction, notes and glossarial index by Franklin Edgerton. London.

(BHSD) Buddhist Hybrid Sanskrit Grammar and Dictionary. Volume II: Dictionary. Indian reprint, Delhi 1970.

Eibl-Eibesfeldt, I

1975 Krieg und Frieden aus der Sicht der Verhaltensforschung. München. Einoo, Shingo

1999 The Autumn Goddess Festival: Described in the Purānas. in: M. Tanaka \& M. Tachikawa (eds.), Living with Śakti. Gender, Sexuality and Religion in South Asia. Osaka 1999. Senri Ethnological Studies No. 50, pp. 33-70.

Elliot, H.M. \& John Dowson

1867-77 The History of India as told by its own Historians. The Muhammadan Period, edited from the posthumous papers of the late H.M. Elliot by John Dowson. London. 8 vols.

Emeneau, M.B.

1958 Oral Poets of South India - the Todas. in: Journal of American Folklore 71 (1958), 312-324.

1988 Sanskrit Studies of M.B. Emeneau. Selected Papers, edit. by B.A. van Nooten. Berkeley.

Encyclopaedia of Islam

(En.Is.) The Encyclopaedia of Islam. New Edition, Leiden. 5 Vols. \& Suppl.

Encyclopaedia of Religion and Ethics

(ERE) The Encyclopaedia of Religion and Ethics. Edit. by James Hastings.

Edinburgh 1921. 13 vols.

Encyclopedia of Indian Temple Architecture

(EITA I) South India. Lower Drāvidadēśa 200 BC - AD 1324. Edited by Michael W. Meister. Coordinated by M.A. Dhaky. Volume I, Part I: Text \& Plates. Delhi 1983. 2 vols.

(EITA II) North India. Foundations of North Indian Style (c. 250 BC - AD 1100. Edited by M.W. Meister \& M.A. Dhaky \& Krishna Deva. Vol. II.1-2. Princeton/New Delhi 1988.

Entwistle, A.W.

1985 An Introduction to Indian Historiography. in: Groniek 92 (1985), 4-15.

1987 Braj. Centre of Krishna Pilgrimage. Groningen. Groningen Oriental Studies Ill.

Epic and Purānic Bibliography

1992 (up to 1985) annotated and with indexes, compiled under the chairmanship of Heinrich von Stietencron [...], edit. by H. von Stietencron, K. P. Gietz, 
A. Malinar, A. Kollmann, P. Schreiner, M. Brockington. Wiesbaden. 2 vols.

Epigraphia Indica

Purāna Research Publications Tübingen Vol. 3.

(EI) A collection of inscriptions supplementary to the Corpus Inscriptionum Indicarum of the Archaeological Survey, translated by several oriental

Erdheim, Mario scholars; ed. by Jas. Burgess [et al.], Calcutta/Bombay 1892-1969. Vol. 1-37.

1973 Prestige und Kulturwandel. Eine Studie zum Verhältnis subjektiver und objektiver Faktoren des kulturellen Wandels zur Klassengesellschaft bei den Azteken. Wiesbaden. Kultur-Anthropologische Studien zur Geschichte. Band 2 .

Eschmann, Anncharlot

1978 The Vaiṣnava typology of hinduization and the origin of Jagannātha. in: Eschmann, A. et al. 1978. pp. 99-117.

Eschmann, Anncharlott \& Hermann Kulke \& Gaya Charan Tripathi (eds.)

1978 The Cult of Jagannāth and the Regional Tradition of Orissa. New Delhi.

Ettinghausen, Maurice L.

1906 Harșa Vardhana, empereur et poète de l'Inde septentrionale (606-648 A.D.). Étude sur sa vie et son temps. Thèse, Paris.

Falk, Harry

1999-2000 The Pātagaṇigūụdem copper-plate grant of the Ikșvāku king Ehavala Cāntamūla. in: Silk Road Art and Archaeology 6 (1999-2000), 275-283.

2000 Bestattungsgebräuche in der Indien betreffenden Archäologie und im vedischen Schrifttum. in: Altorientalische Forschungen 27 (2000), 68-80.

2004 The Kanișka era in Gupta records. in: Silk Road Art and Archaeology 10 (2004), 167-76.

Farquhar, J.N

1925 The Fighting Ascetics of India. in: Bulletin of the John Rylands Library, Manchester, vol. 9 (1925), 431-52.

Finnegan, Ruth

1977 Oral Poetry. Its nature, significance and social context. Cambridge.

Fleet, J.F.

1885 Sanskrit and Old-Kanarese Inscriptions. No. CLIX: Paithan Plates of

Ramachandra - Saka 1193. in: Indian Antiquary 14 (1885), 314-19.

Foekema, Gerardus Maria Majella

2003 Architecture decorated with architecture. Later medieval temples of

Karnātaka, 1000 - 1300 AD. New Delhi. [thesis, University of Leiden].

Folkert, Kendall W.

1989 Jain Religious Life at Ancient Mathurā: The Heritage of Late Victorian

Interpretation. in: Srinivasan, D.M. (ed.), Mathurā. The Cultural heritage. New Delhi. pp. 103-22.

Frank, Othman

1808 Das Licht vom Orient. Nürnberg/Leipzig.

1820-21 Bhagavadgitae loca selecta cum versione. in: O. Frankii Chrestomathia

Sanskrita 1820-21 (17 vols.). Vol. 2 Pt. 3, 83-115.

Franz, Heinrich Gerhard

1978 Pagoda, Turmtempel, Stupa. Studien zum Kultbau des Buddhismus in Indien und Ostasien. Graz.

Frauwallner, E.

1925a Untersuchungen zum Mokșadharma (Die nicht-sāṃkhyistischen Texte). in:

Journal of the American Oriental Society 45 (1925), 51-67 [=Kleine Schriften, Wiesbaden 1982, 38-54].

1925b Untersuchungen zum Mokșadharma (Die sāmkhyistischen Texte). in: Wiener Zeitschrift für die Kunde des Morgenlandes 32 (1925), 179-206 [=Kleine Schriften, Wiesbaden 1982, 55-82]. 
1951 On the date of the Buddhist Master of the Law Vasubandhu. Roma. Serie Orientale Roma III.

1953 Geschichte der indischen Philosophie. Band I, Salzburg.

1992 Philosophische Texte des Hinduismus. in: Nachgelassene Werke II, herausgegeben von G. Oberhammer und C.H. Werba, Wien.

Freitag, Sandria B.

1989 Collective Action and Community. Public Arenas and the Emergence of Communalism in North India. Berkeley/Los Angeles/Oxford.

Führer, A.

1891 The Monumental Antiquities and Inscriptions in the North-Western Provinces

Fussman, Gérard and Oudh. Allahabad.

1989 The Māt devakula: A New Approach to Its Understanding. in: Srinivasan, D.M. (ed.), Mathurā. The Cultural heritage. New Delhi. pp. 193-199.

Fyzabad Gazetteer

(Fyz. Gaz.) Fyzabad: a Gazetteer being Volume XLIII of the District Gazetteers of the United Provinces of Agra and Oudh by H.R. Nevill. Allahabad 1905.

Gaeffke, Peter

1982 [Review of] J.W. Sedlar, 'India in the mind of Germany. Schelling, Schopenhauer and their times'. in: JAOS 102.3 (1982), 549-550.

1984 De symbolis in litteris indicis mediae aetatis. in: Ozols, J. \& V. Thewalt (eds.), Aus dem osten des Alexandereichs. Völker und Kulturen zwischen Orient und Okzident. Iran, Afghanistan, Pakistan und Indien. Köln. pp. 84-99.

Gai, G.S.

1969 Three Inscriptions of Rāmagupta. in: Journal of the Oriental Institute, M.S.

University of Baroda XVIII (1969), 247-251.

Gai, G.S. \& S. Sankaranarayanan

1967-68 Note on the date of Hisse-Borala inscription of the time of Vākātaka

Gail, A.

1969 Buddha als Avatāra Viṣnus im Spiegel de Purāṇas. in: ZDMG (Suppl. I,

XVII. Deutscher Orientalistentag, Teil 3). Wiesbaden. pp. 917-23.

1977a Paraśurāma. Brahmane und Krieger. Untersuchung über Ursprung und

Entwicklung eines Avatāra Vișnu und Bhakta Śivas in der indischen Literatur. Wiesbaden.

1977b Visnu als Eber in Mythos und Bild. in: Beiträge zur Indienforschung. Ernst Waldschmidt zum 80. Geburtstag gewidmet. Berlin. pp. 127-68.

2008 The Enlightened Buddha and the Preaching Śiva. More Light on the Dakṣināmūrti icon. in: Raven, Ellen M. (ed.), South Asian Archaeology 1999. Groningen. pp. 457-462.

Gaṇakārikā

Garde, M.B.

See Dalal 1920.

1940 Annual Administration Report of the Archæological Department Gwalior State for Vikram Samvat 1995, year 1938-39. Archæological Department Gwalior State, Gwalior.

Geertz, Clifford

1980 Negara. The Theatre State in Nineteenth-Century Bali. Princeton.

Gambier-Parry, T. R.

1930 A Catalogue of Photographs of Sanskrit MSS purchased for the administrators of the Max Müller Memorial Fund. Oxford/London.

Geer, Alexandra Anna Enrica van der

1998 The Bhāsa Problem. A statistical research into its solution. Thesis, Leiden. 
Ghosh, A.

1973 The city in early historical India. Simla.

(EIA) An Encyclopaedia of Indian archaeology. Vol. I: Subjects. Vol. II: A Gazetteer of Explored and Excavated Sites in India. Delhi 1989.

Ghurye, G.S.

1953 Indian Sadhus. Bombay.

Giuliano, Laura

2006 Il simbolismo della montagna cosmica nell'architettura hindū. Il percorso devozionale che conduce all'assoluto. in: Barbero, Amilcare \& Stefano Piano (eds.), Religioni e Sacri Monti, Atlas, Ponzano Monferrato. pp. 177-200.

Gladigow, Burkhard

1986 Homo publice necans. Kulturelle Bedingungen kollectiven Tötens. in: Saeculum 37 (1986), 150-65.

Gobhilagṛhyasūtra

(GoGS) Gobhilagṛhyasūtram with Bhațtanārāyaṇa's commentary. Crit. edit. from the original manuscripts with notes and indices by Chintamani Bhattacharya.

With an Introduction by V. Vedantatirtha. Calcutta 1936. The Calcutta Sanskrit Series No. XVII

Gokhale, Shobana

1967-68 Hisse-Borala Inscription of Devasena, Śaka 380. in: EI, XXXVII (1967-68), $1-4$.

Gonda, Jan

1960-63 Die Religionen Indiens. Stuttgart. 2 Vols. Die Religionen der Menschheit Band 11, 12.

1965 Change and Continuity in Indian Religion. London-The Hague-Paris. Disputationes Rheno-Trajectinae IX.

1969 Ancient Indian Kingship from the Religious Point of View. Leiden.

1977 Medieval Religious Literature in Sanskrit. Wiesbaden. A History of Indian Literature II.1.

1977a The Ritual Sūtras. Wiesbaden. A History of Indian Literature I.2.

1980 Vedic Ritual. The Non-solemn Rites. Leiden. Handbuch der Orientalistik, zweite Abteilung: Indien, vierter Band: Religionen, erster Abschnitt: Vedic Ritual.

Goodall, Dominic

1998 Bhatța Rāmakaṇțha's Commentary on the Kiraṇatantra. Vol. I: chapters 1-6. Critical edition and annotated translation. Pondichéry. Publications du Département d'Indologie 86.1.

2004 The Parākhyatantra. A Scripture of the Śaiva Siddhānta. A Critical Edition and Annotated Translation by - -. Pondichéry. Collection Indologie 98.

Goodall, Dominic \& Harunaga Isaacson

2007 Workshop on the Niśvāsatattvasamhitā: The Earliest Surviving Śaiva Tantra? in: Newsletter of the NGMCP 3 (2007), 4-6.

Gopal, Ram

1959 India of the Vedic Kalpasūtras. Delhi.

Gopālarājavaṃsāvalī

A facsimile edition prepared by the Nepal Research Centre in collaboration with the National Archives, Kathmandu. With an introduction, a transcription, Nepali and English translations, a glossary and indices [by]

Dhanavajra Vajrācārya and Kamal P. Malla. Wiesbaden 1985. Nepal Research Centre Publications No. 9.

Gopathabrāhmana

Das Gopatha Brāhmaṇa edit. by Dieuke Gaastra. Leiden 1919. 
Goswamy, Brijinder Nath

1980 Introductory Speech: the Stūpa-some uninformed questions about terminological equivalents. in: Dallapiccola, Anna Libera (ed.), The Stūpa. Its religious, historical and architectural significance. Wiesbaden. pp. 1-11.

Goudriaan, Teun \& Sanjukta Gupta

1981 Hindu Tantric and Śākta Literature. Wiesbaden. A History of Indian Literature Vol. III fasc. 2.

Govindasvāmī

Sāhityik viśleșan vārtā aur pada-saṃraha. Edit. by Brajabhūṣaṇa Śarmā and Goyal, Shankar Kaṇțhamaṇi S̉āstrī and Gokulānanda Tailañga. Kankroli VS 2008.

1992 History and Historiography of the Age of Harsha. With a foreword by K.D. Bajpai. Jodhpur.

Goyal, S.R.

1967 A History of the Imperial Guptas. Allahabad.

Gramlich, R.

1965-81 Die schiitischen Derwischorden Persiens. Erster Teil: 'Die Affiliationen'.

Zweiter Teil: 'Glaube und Lehre'. Dritter Teil: 'Brauchtum und Riten'.

Wiesbaden 1965, 1976, 1981. 3 Vols. Abh. für die Kunde des Morgenlandes

Granoff, Phyllis

Bde. XXXVI, 1, XXXVI, 2-4, XLV, 2.

1992 Worship as Commemoration: Pilgrimage, Death and Dying in Medieval

Jainism. in: Bulletin d'Études Indiennes 10(1992), 181-202.

1992a The Householder as Shaman. Jaina Biographies of Temple Builders. in: East and West 42 (1992), 301-317.

2001 Portraits. Likenesses and Looking Glasses: some literary and philosophical reflections on representation and art in medieval India. in: Assman, Jan \& A.I. Baumgarten (eds.), Representation in Religion. Studies in Honor of Moshe Barasch. Leiden. pp. 63-105.

2006 Reading between the Lines: Colliding Attitudes towards Image Worship in Indian Religious texts. in: Colas, Gérard \& Gilles Tarabout (eds.), Rites hindous. Transferts et transformations. Paris. = Puruṣārtha 25 (2006), pp. 389-422.

Greaves, Laxshmi Rose

2015 Brick Foundations: North Indian Brick Temple Architecture and Terracotta

Grenet, Frantz Art of the Fourth to Sixth Centuries CE. Cardiff University, Cardiff (thesis).

2015 Zoroastrianism among the Kushans. in: Falk, Harry (ed.), Kushan Histories. Literary Sources and Selected Papers from a Symposium at Berlin, December 5 to 7, 2013. Hempen Verlag, Bremen. pp. 203-39.

Grünendahl, Reinhold

1983-89 Viṣnudharmāḥ, Precepts for the worship of Viṣnu. Part 1: Adhyāyas 1-43. Part 2: Adhyāyas 44-81. Part 3: Adhyāyas 82-105 (with a Pāda-index of Adhyāyas 1-105). Wiesbaden. 3 vols.

1989 Catalogue of Palm-leaf and Selected Paper Mss belonging to the Durbar Library, Nepal (to which has been added a Historical Introduction by C. Bendall), Calcutta 1905. Reprinted with a concordance by Reinhold Grünendahl. Stuttgart. Verzeichnis der orientalischen Handschriften in Deutschland, Supplementband 31.

Gupta, Ananda Swarup

1970 A problem of purāṇic text-reconstruction. in: Purāṇa XII No. 2 (1970), 304-21.

Gupta, Chandrashekhar

1992 Paunar under the Vākāțakas. in: A.M. Shastri (ed.), The Age of the Vākāțakas. New Delhi, 119-53. 
Gupta, Parmeshwari Lal

1946 Ghațotkacagupta. in: Indian Historical Quarterly 22 (1946), 316-319.

1989 Early Coins of Mathurā Region. in: Srinivasan 1989 (Mathurā. The Cultural Heritage), pp. 124-139.

Gupta, S.P.

1972 Disposal of the Dead and Physical Types in Ancient India. Delhi.

Gupte, Y.R.

1915-16 Two Talesvara Copperplates. in: EI XIII (1915-16) No. 7, 109-21.

Hacker, $\mathrm{P}$.

1960a Zur Entwicklung der Avatāralehre. in: WZKSA IV (1960), 47-70.

1960b Prahlāda. Werden und Wandlungen einer Idealgestalt. Beiträge zur Geschichte des Hinduismus. Wiesbaden. Ak. d. Wiss. u. d. Lit. Abh. d.

Geistes- u. Sozialwiss. Kl. Jahrgang 1959, Nr. 9, 13.

1961a Zur Methode der geschichtlichen Erforschung der anonymen Sanskritliteratur des Hinduismus. in: ZDMG 111 N.F. Bd. 36 (1961), 483-92.

1961b The Sāmkhyization of the Emanation Doctrine (Shown in a Critical Analysis of Texts). in: Wiener Zeitschrift für die Kunde Süd- und Ostasiens 5 (1961), 75-112 [=Kleine Schriften 1978, 167-204].

1978 Schopenhauer und die Ethik des Hinduismus. in: Paul Hacker, Kleine Schriften. Herausgegeben von Lambert Schmithausen. Wiesbaden. pp. 531-564.

Härtel, Herbert

1987 Archaeological Evidence on the Early Vāsudeva Worship. in: 'Orientalia

Josephi Tucci Memoriae Dicata'. Edenda curaverunt G. Gnoli et L. Lanciotti. Roma, Vol. 2, 573-587.

Halbfass, Wilhelm

1981 Indien und Europa. Perspektiven ihrer geistigen Begegnung. Basel/Stuttgart.

1983 Inklusivismus. in: Gerhard Oberhammer (Hrsg.), Inklusivismus. Eine indische Denkform. Wien. pp. 11-28.

Hamilton, A. \& L.Langlès

1807 Catalogue des manuscrits sanskrits de la bibliothèque impériale. Avec notices du continu de la plupart des ouvrages etc. Paris.

Handiqui, Krishna Kanta

1965 Naiṣadhacarita of Śrīharșa. For the first time translated into English with critical Notes and Extracts from unpublished Commentaries, Appendices and

Hara, Minoru a Vocabulary. Poona.

1958 Nakulīśa-Pāśupata-Darśanam. in: IIJ II (1958), 8-32.

1967 Materials for the study of Pāśupata Śaivism. PhD Thesis, Harvard University 1967.

1999 Pāśupata and Yoga. Pāśupata-sūtra 2.12 and Yoga-sūtra 3.37. in: Asiatische Studien/Études Asiatiques LIII.3 (1999), 593-608.

2002 Pāśupata Studies. Edit. by Jun Takashima. Vienna. Publications of the De Nobili Research Library XXX.

Hardy, Friedhelm.

1974 Mādhavêndra Purī: a link between Bengal Vaiṣnavism and South Indian bhakti. in: JRAS (1974), 23-41.

1983 a Viraha-Bhakti. The early history of Kṛșna devotion in South India. Delhi etc.

1983b Viraha in relation to concrete space and time. in: Thiel-Horstmann, Monika (ed.), Bhakti in Current Research, 1979-1982. Berlin. pp. 143-55. 
Harivamśa

(HV) The Harivamśa being the Khila or supplement to the Mahābhārata. For the first time critically edited by P.L. Vaidya. Poona 1969-71. 2 vols.

Harle, J.C.

1986 The art and architecture of the Indian subcontinent. Harmondsworth. The Pelican History of Art.

1987 The 'pleated' śiraścakra. in: Kusumañjali. C. Sivaramamurti Commemoration Volume II, edit. by Nagaraja Rao, Delhi. pp. 234-37.

Harșadeva

Ratnāvalī [edit. by C. Cappeller] in: Otto Böhtlingk, Sanskrit-Chrestomathie, 3. verbesserte und vermehrte Auflage [von R. Garbe], Leipzig 1909. pp. $326-369$.

Harting, Nicolaas Ubbo

1922 Selections from the Baudhāyana-Gṛhyapariśișțasūtra. Amersfoort. Ph. D. Thesis, Rijksuniversiteit Utrecht.

Heesterman, J.C.

1984 Non-Violence and Sacrifice. in: Indologica Taurinensia XII (1984), 119-127.

1985 The Inner Conflict of Tradition. Essays in Indian Ritual, Kingship, and Society. Chicago/London.

Hegel, Georg Wilhelm Friedrich

1827 Ueber die unter dem Nahmen Bhagavad-Gita bekannte Episode des Mahabharata von Wilhelm von Humboldt. Berlin 1825-26 [1828]. in: Jahrbücher für wissenschaftliche Kritik: 'Erster Artikel' in Nro. 7 u. 8 (Januar 1827), pp. 51-63; 'Zweiter Artikel' in Nro. 181 u. 182 (October 1827), pp. 1441-88; 'Beschluß' in Nro. 187 u. 188 (October 1827), pp. 1489-92. in: G.W.F. Hegel Werke 11, Berliner Schriften 1818-1831. Auf der Grundlage der Werke von 1832-1845 neu edierte Ausgabe. Redaktion Eva Moldenhauer und Karl Markus Michel. Frankfurt 1970. Theorie-Werkausgabe.

1832-45 Werke Vollständige Ausgabe durch einen Verein von Freunden des Verewigten: Plilipp Marheineke (etc.). Berlin. 18 vols.

1928 Vorlesungen über die Aesthetik. Teilbd. 1. Hrsg. von Georg Lasson. Leipzig 1928. Sämmtliche Werke Bd. 10a.

1940 System und Geschichte der Philosophie. Vollständig neu nach den Quellen hrsg. von Johannes Hoffmeister. Leipzig 1940 (1944²). Sämmtliche Werke. Kritische Ausgabe Band XVa: Vorlesungen über die Geschichte der Philosophie. Einleitung: System und Geschichte der Philosophie.

Philosophische Bibliothek Bd. 166. (3. gekürzte Auflage besorgt von Friedhelm Nicolin. Hamburg $\left.1959\left(1966^{2}\right)\right)$.

1955 Grundlinien der Philosophie des Rechts. Mit Hegels eigenhändigen Randbemerkungen in seinem Handexemplar der Rechtsphilosophie. Hrsg. von Johannes Hoffmeister. Hamburg 1955. Philosophische Bibliothek Bd. 124a.

1955 Vorlesungen über die Philosophie der Weltgeschichte. Erste Hälfte. Bd. 1: Die Vernunft in der Geschichte, hrsg. von Johannes Hoffmeister (1955). Zweite Hälfte. Bd. 2: Die orientalische Welt; Bd. 3: Die griechische und die römische Welt; Bd. 4: Die germanische Welt, auf Grund der Handschriften hrsg. von Georg Lasson. Hamburg 1923², 1955. 2 vols. Philosophische Bibliothek Bde. $171 \mathrm{a}, \mathrm{b}-\mathrm{d}$.

1983-1985 Vorlesungen über die Philosophie der Religion. Teil 1: Einleitung. Der Begriff der Religion. Teil 2: Die bestimmte Religion (a: Text; b: Anhang). Teil 3: Die vollendete Religion. Herausgegeben von Walter Jaeschke. Hamburg 1983-1985. 4 vols. Georg Wilhelm Friedrich Hegel Vorlesungen. Ausgewählte Nachschriften und Manuskripte Bde. 3, 4a/b, 5. 
(Briefe) Briefe von und an Hegel. Herausgegeben von Johannes Hoffmeister (Bd. IV 1/2 hrsg. von Friedhelm Nicolin). Hamburg 1952-1981. 4 Bde. Philosophische Bibliothek Bde. 235-238 (a, b).

(Hegel BhG) Siehe Hegel 1827.

(Hegel Einleitung) Siehe Hegel 1940.

Hegel in Berlin

1981 Preussische Kulturpolitik und idealistische Aesthetik. Zum 150. Todestag des Philosophen. Ausstellung der Staatsbibliothek Preussischer Kulturbesitz Berlin, [...] Berlin 11. November 1981. Herausgeber des Katalogs: Otto Pöggeler. Wiesbaden 1981. Staatsbibliothek Preussischer Kulturbesitz

Heine, Heinrich Ausstellungskataloge 16.

Sämmtliche Schriften in zwölf Bänden. Herausgegeben vor Klaus Briegleb. Band V: Schriften 1831-1837, hrsg. von Karl Pörnbacher. München/Wien 1976 .

Hemādri

(CVC) Caturvargacintāmaṇi of Śr̄̄ Hemādri. Originally published by the Asiatic Society of Bengal in 1871. Reprint, Varanasi 1985. 7 vols.

Herder, Johann Gottfried

1772 'Abhandlung über den Ursprung der Sprache', welche den von der Königl. Academie der Wissenschaften [...] gesezten Preis erhalten hat. Berlin. Sämmtliche Werke. Hrsg. von Bernhard Suphan. Berlin 1877-1913. 33 vols.

Herklots, G.A.

1921 Jacfar Sharīf, Islam in India or Qānūn-i-Islām. Translated by G.A. Herklots. Edit. by W. Crooke. Oxford.

Het Rijk der Scythen

Catalogus van de gelijknamige tentoonstelling in De Nieuwe Kerk te

Hindu Scriptures Amsterdam onder redactie van John Vrieze. Zwolle/Amsterdam 1993.

Edited with new translations by Dominic Goodall. Based on an anthology by R.C. Zaehner. London 1996.

Hinüber, Oskar von

2001 Das ältere Mittelindisch im Überblick. 2., erweiterte Auflage. Wien. Österreichische Akademie der Wissenschaften, Phil. -hist. Kl. 467. Band.

2004 Die Palola Șāhis. Ihre Steininschriften, Inschriften auf Bronzen, Handschriftenkolophone und Schutzzauber. Materialien zur Geschichte von Gilgit und Chilas. Mainz. Heidelberger Akademie de Wissenschaften, Antiquities of Northern Pakistan. Reports and Studies Vol. 5.

Hiralal, Rai Bahadur

1908 A visit to Ramtek. in: Indian Antiquary 37 (1908), 202-08.

1932 Inscriptions in the Central Provinces and Berar. Nagpur.

Hiranyakeśigṛhyasūtra

(HirGS) The Grihyasūtra of Hiranyakeśin with extracts from the commentary of Mātridatta. Edit. by J. Kirste. Vienna 1889.

History and Culture of the Indian People

(HCI) Edit. by R.C. Majumdar and others. Bombay 1951-1977. 11 vols. Hoekstra, A.

1965 Homeric Modifications of Formulaic Prototypes. Studies in the development of Greek epic diction. Amsterdam. Verh. d. Kon. Ak. v. Wet. Afd. Lett. NR Deel LXXI No. 1.

Hofstra, Jan

2008 Leontius von Neapolis und Symeon der heilige Narr. Ein Pastor als

Hagiograph. Verlag Karmel, Drachten. [thesis defended at the University of Groningen, 18-9-2008]. 
Höpfner, G.

1921 Die indischen Studien Friedrich Schlegels im Zusammenhang seinen Denkens. Breslau (Diss.).

Hubbeling, Hubertus G.

1990 Some remarks on the Concept of person in Western Philosophy. in:

Kippenberg, H.G., Yme B. Kuiper and Andy F. Sanders (eds.), Concepts of

Hulin, Michel

Persons in Religion and Thought. Berlin/New York 1990. pp. 9-24.

1979 Hegel et l'Orient. Suivi de la traduction annotée d'un essai de Hegel sur la

Bhagavad-gîtâ. Paris.

Humboldt, Wilhelm von

1826 Ueber die Bhagavad-Gita. Mit Bezug auf die Beurtheilung der Schlegelschen

Ausgabe im Pariser Asiatischen Journal. in: Indische Bibliothek Bd. II (1826),

Heft 2, pp. 218-258; Heft 3 pp. 328-372.

1828 Ueber die unter dem Namen Bhagavad-Gítá bekannte Episode des

Mahá-Bhárata (gelesen in der Akademie der Wissenschaften am 30. Juni 1825

und 15. Juni 1826). in: Abh. d. hist.-phil. Kl. der Kön. Ak. d. Wiss. zu Berlin aus dem Jahre 1825. Berlin 1828. pp. 1-44, 45-64. (in: Wilhelm von

Humboldts Gesammelte Schriften, hrsg. von der Kön. Preuss. Ak. d. Wiss. 5.

Band (1823-26), hrsg. von Albert Leitzman, Berlin 1906 [Nachdruck Berlin

1968], pp. 190-232, 325-344).

(Humboldt BhG) Siehe Humboldt 1828.

Hunter, G.R.

1934 Unknown pictographic script near Ramtek, C.P. in: Journal of the Bihar and Orissa Research Society XX (1934), 10-12.

Huntington, Susan L.

1985 The Art of Ancient India. Buddhist, Hindu, Jain. With Contributions by

John C. Huntington. New York/Tokyo.

Huussen, A.H. Jr.

1991 De Tachtigjarige oorlog. in: Bakker \& Gosman 1991, pp. 134-51.

Ibn Bațtūța

The Travels of Ibn Batṭutța. A.D. 1325-1354. Translated with revisions and notes from the Arabic text edited by C. Defrémery and B.R. Sanguinetti by H.A.R. Gibb. Vol. IV. The translation completed with annotations by C.F. Beckingham. London 1994. Works issued by the Hakluyt Society Second Series No. 178.

Ikari, Yasuke \& Takao Hayashi

1994 Ādipurāna. in: Ikari, Yasuke (ed.), A Study of the Nīlamata. Aspects of Hinduism in Ancient Kashmir. Kyoto. pp. 83-136.

Indian Antiquary

(IA) Journal of Oriental Research in Archaeology, History, Literature, Languages, Folklore, etc., edited by Jas. Burgess [et al.], Bombay 1872-1933, Vol. 1 - 62 . Indian Archaeology - A Review

(IAR) Archaeological Survey of India, New Delhi.

Indian Historical Quarterly

(IHQ) The Indian Historical Quarterly, 1925-63. Calcutta.

Indische Bibliothek

(Ind. Bib.) Eine Zeitschrift von August Wilhelm von Schlegel. Bonn 1823-1830. Vols. I-III.

Indo-Iranian Journal

(IIJ) 's-Gravenhage, Dordrecht, Leiden, 1957 - Vol. 1 -

Indraji, Bhagvānlāl

1881-82 Antiquarian Remains at Sopârâ and Padana. in: Journal of the Bombay Branch of the Royal Asiatic Society 15 (1881-82). [Published in 1883] 
Ingalls, Daniel H.H.

1962 Cynics and Pāśupata: the Seeking of Dishonor. in: Harvard Theological Review (1962), 289-291.

Internationales Asienforum

1994 International Quarterly for Asian Studies 25. Jahrgang, November 1994, 3-4/94. Weltforum Verlag, München-Köln-London.

Irwin, John

1980 The Axial Symbolism of the Early Stūpa: an Exegesis. in: Dallapiccola, Anna Libera (ed.), The Stūpa. Its religious, historical and architectural significance. Wiesbaden. pp. 12-38.

Iyer, T. Paramasiva

1940 Ramayana and Lanka, Pts. I \& II. Bangalore.

Jābāla Upaniṣad

(JābU) The Jābāla Upaniṣad. in: S. Radhakrishnan, The principal Upaniṣads edit. with Introduction, Text. Translation and Notes. London 1953. pp. 893-900.

Jain, Kailash Chand

1972 Malwa Through the Ages (from the earliest times to 1305 AD). Delhi etc.

Jalhana

The Sūktimuktāvalī of Bhagadatta Jalhana, edit. with an Introduction in Sanskrit by Embar Krishnamacharya. Baroda 1938. Gaekwad's Oriental Series, No. LXXXII.

Jambūdvīpaprajñapti

The Jambuddivvapaṇnattī with the (Sanskrit) gloss of Dharmasāgaraganivara, Jamkhedkar, A.P. edit. by Labhsagargani. Gopipura 1977. Āgamoddhāraka Series 57.

1974 Narrative sculptures from Markandi. in: Journal of the Oriental Institute (of Baroda), XXIII.3 (1974), 202-08.

1985a Narrative sculptures from Paunar: A Reappraisal. in: Gay, A (ed.), Indian Epigraphy. New Delhi. pp. 83-86.

1985b Buddhist bronzes from Ramtek. in: Lalit Kalā, No. 22 (1985), 13-19.

1985-86 Ancient Structures. in: Mārg 37 No. 1 (1985-86), 25-36.

1987a Vaiṣnavism in the Vākātaka Times. in: Parimoo, R. (ed.), Vaiṣnavism in Indian Arts and Culture. New Delhi 1987 [= 1986]. pp. 335-41.

1987b A Newly Discovered Vākāțaka Temple at Ramtek, Dist. Nagpur. in: Nagaraja Rao (ed.), Kusumāñjali. C. Sivaramamurti Commemoration Volume. Delhi. pp. 217-23.

1988 Beginnings of North Indian Style: Early Vidarbha Style, c. AD 350-500. Vākātakas (Main Branch). in: EITA II.1, 59-72.

1992 Discovery of Vākāṭaka temples at Ramtek. in: Shastri 1992, 155-64.

Jayaswal, Vidula

2001 Royal Temples of Gupta Period (excavations at Bhitari). Aryan Books, New Delhi 2001.

Jayaswal, Vidula \& Arvind Kumar Singh \& Meera Sharma

2017 The Sacred Landscape of Mundeshwari. The 'Oldest Living' Temple. Aryan Books/Jñāna-Pravāha, New Delhi/Varanasi. New Discoveries in the History of Varanasi 5.

Jha, Shaktidhar

1978 Aspects of Brahmanical influence on the Jaina Mythology. Delhi.

Johnston, E.H.

1937 Early Sāmkhya: An Essay on its Historical Development according to the Texts. London. 
Jolly, Julius

1896 Recht und Sitte (einschliesslich der einheimischen Litteratur). Strassbourg, 1896. (Grundriss der Indo-Arischen Philologie und Altertumskunde II. Band, 8. Heft.

Jones, William

1788 The third Anniversary Discourse delivered 2nd February, 1786 by the President [of the Asiatic Society of Bengal]. in: Asiatic Researches or Transactions of the Society. Vol. 1 (1788), 343-355.

1789 Sacontalá, or the Fatal Ring. An Indian drama [by Kālidāsa] ... translated from the original Sanscrit and Prácrit. Calcutta.

1794 Institutes of Hindu Law, or the ordinances of Manu, according to the gloss of Culluca. Comprising the Indian system of duties, religious and civil. Verbally translated from the original Sanscrit. Calcutta. (Reprinted in London 1796).

Jordaan, Roy E. \& Robert Wessing

1999 Construction Sacrifice in India, "Seen from the East." in: Jan E.M. Houben \& Karel R. van Kooij (eds.), Violence Denied. Leiden. pp. 211-247.

Joshi, Jagat Pati \& A.K. Sharma

1999-2000 Excavation at Mansar, Dist. Nagpur, Maharashtra, 1997-2000. in: Purātattva, Bulletin of the Indian Archaeological Society 30 (1999-2000), 127-131.

2005 Mansar Excavations 1998-2004: The discovery of Pravarapur. in:

Purāmanthana 'Current Advances in Indian Archaeology. Pravarpur Special', Vol. 3 (2005), pp. 1-26.

Joshi, M.C.

1975-76 Archaeology and Indian Tradition: Some Observations. in: Purātattva (Bull. of the Ind. Arch. Soc.) 8 (1975-76), 98-102.

1979-80 Ayodhya: Mythical and Real. in: Purātattva 11 (1979-80), 107-109.

1992 Royal Succession in the Gupta Age and the Connotation of the Term Dauhitra Occuring in Inscriptions. in: R.Ch. Chhabra et al. (eds.), Reappraising Gupta History for S.R. Goyal. New Delhi. pp. 111-126.

Joshi, N.P.

1989 Brahmanical Sculptures in the State Museum, Lucknow. Part II, Vol. 1 (Śiva and Viṣnu). Part II, Vol. 2 (Gaṇapati, Skanda, Brahmā, Sūrya, Revanta, Grahas, Śakti-images and Minor Divinities). Lucknow. 2 vols.

1989a Early Jaina Icons from Mathurā. in: Srinivasan, D.M. (ed.), Mathurā. The Cultural Heritage. New Delhi. pp. 332-367.

Journal Asiatique

(JA) Un Receuil de Mémoires, d'Extraits et de Notices relatifs à l'Histoire, à la Philosophie, aux Sciences, à la Litérature et aux Langues des Peuples Orientaux. Publié par la Société Asiatique. Paris 1822- .

Journal of the Bihar Research Society

(JBRS) Bihar Research Society, Bankipore 1943-

Journal of the Epigraphical Society of India

(JESI) Mysore, 1975-

Journal of the Numismatic Society of India

(JNSI) Varanasi, 1939- .

Journal of the Royal Asiatic Society

(JRAS) London, 1834- .

Jouveau-Dubreuil, G.

1920 Ancient History of the Deccan. Pondichérry.

Kafle, Nirajan

2015 The Niśvāsamukha, the Introductory Book of the Niśvāsatattvasaṃhitā.

Critical Edition, with an Introduction and Annotated Translation. Appended by Śivadharmasamgraha 5-9. Leiden (thesis). 
Kailasapathy, K.

1968 Tamil Heroic Poetry. Oxford.

Kālidāsa

The complete works of Kālidāsa: the text in Sanskrit and Prakrit, edit. with an introduction by V.P. Joshi. Leiden 1976.

Kālidāsa Granthāvalī [Complete works of Kālidāsa] crit. edit. by Revāparsāda Dvived̄̄. Varanasi 1976.

Vallabhadeva's Kommentar (Śāradā-Version) zum Kumārasaṃbhava des Kālidāsa hrsg. von M. S. Narayana Murti, unter der Mitarbeit von Klaus L. Janert. Wiesbaden 1980.

Kālidāsa's Meghadūta. Edit. from the Manuscripts with the Commentary of Vallabhadeva and provided with a complete Sanskrit-English Vocabulary [by] E. Hultzsch. With a Foreword by Albrecht Wezler. New Delhi 1998.

The Raghuvamśa of Kâlidâsa, with the commentary of Mallinâtha, edit. with various readings by Kâsînâtha Pânduranga Paraba. Third edition. Bombay, 1886.

The Raghupañcikā of Vallabhadeva, being the earliest commentary on the Raghuvamśa of Kālidāsa. Vol. I. Critical Edition with Introduction and Notes by Dominic Goodall \& Harunaga Isaacson. Groningen 2003. Groningen Oriental Studies 17.

Kalidos, Raju

1991 Buddhist parallels in Hindu iconography: a case study of Daksinamūrti. in: R. Parimoo et.al. (eds.), The Art of Ajanta. New Perspectives. New Delhi. 2 vols.

Kane, P.V.

1930-62 History of Dharmaśāstra (Ancient and Mediaeval Religious and Civil Law in India). Poona. 5 vols. Government Oriental Series, Class B, No. 6. [= Kane I to $\mathrm{V}]$

Kangle, R.P.

1963-65 See Arthaśāstra

Karttunen, Klaus

1989 India in Early Greek Literature. Finnisch Oriental Society, Helsinki. Studia Orientalia 65.

1997 India and the Hellenistic World. Finnisch Oriental Society, Helsinki. Studia Orientalia 83.

Kātyāyanaśrautasūtra

(KŚS) The Śrautasūtra of Kātyāyana. With extracts from the commentaries of Karka and Yājñikadeva edit. by Albrecht Weber. Reprint, Varanasi 1972. The Chowkhamba Sanskrit Series 104

Kaumudimahotsava

Kaumud̄̄ Mahôtsava. Edit. by M. Ramakrishna Kavi and S.K. Ramanatha Sastri. Trivandrum 1929. Andhra Oriental Series 1.

Kaușitaki Brāhmaña

(KauṣBr) The Kaușītaki-Brāhmana [with the] Vyākhyā of Udaya. Edit. by E.R. Sreekrishna Sarma. Wiebaden 1968-1976. 3 vols. Verzeichnis der orientalischen Handschriften in Deutschland. Supplementband 9.1-3.

Kaușitaki Upaniṣad

(KaușU) in: Limaye, V. P. \& R. D. Vadekar (eds.), Eighteen Principal Upanișads. Vol. I. Upanișadic Text with Parallels from extant Vedic Literature, Exegetical and Grammatical Notes. Poona 1958. Gandhi Memorial Edition.

Kielhorn, F.

1886 Two copper-plate grants of Jayachchandra of Kanauj. in: Journal asiatique XV (1886), 6-13. 
Kippenberg, Hans G.

1991a Heilige Oorlogen: Godsdienstwetenschappelijke Aspecten. in: Bakker \& Gosman 1991, pp. 18-36.

1991b Revolt against Modernism: A note on some recent comparative studies in fundamentalism. in: Numen XXXVIII.1 (1991), 128-133.

Kirfel, Willibald

1915 Die Anfänge des Sanskrit-Druckes in Europa. in: Zentralblatt für Bibliothekswesen 32 (1915), 274-280. [in: Kleine Schriften. Hrsg. von R. Birwé. Wiesbaden 1976. Glasenapp Stiftung 11].

1927 Das Purāna Pañcalakșaṇa. Versuch einer Textgeschichte. Leiden.

1944 August Wilhelm von Schlegel und die Bonner indologische Schule. Bonn. Kriegsvorträge der Rheinischen Friedrich-Wilhelms-Universität, Bonn a. Rhein 133.

Kirk, G.S. \& J.E. Raven

1975 The Presocratic Philosophers. A critical history with a selection of texts. Cambridge.

Kolte, V.B.

1965 Hisse-Borala Inscription of Vākātaka King Devasena. in: Mirashi Commemoration Volume, edit. by G.T. Deshpande and A.M. Shastri. Nagpur. pp. 372-87.

1971-72 Dvitīya Pṛthīṣenācā Māhurjhar̄̄ Tāmrapat. in: Vidarbha Saṃśodhana Mạ̣dala Vārșika 1971-72, 53-77.

Korolkova, E.F.

2017 Death and Burial. in: Simpson, St John \& Svetlana Pankova (eds.), Scythians. Warriors of Ancient Siberia. The British Museum, London. pp. 258-75.

Kramrisch, Stella

1961 Pūṣan. in: JAOS 81 (1961), 104-122.

1977 The Hindu Temple. Reprint, Delhi etc. (First edition, Calcutta 1946). 2 vols. Kreisel, Gerd

1986 Die Śiva-Bildwerke der Mathurā-Kunst. Ein Beitrag zur frühhinduistischen Ikonographie. Stuttgart. Monographien zur indischen Archäologie, Kunst und Philologie Vol. 5.

Kreiss, Friedrich

1941 Hegels Interpretation der indischen Geisteswelt. in: Zeitschrift für Deutsche Kulturphilosophie (Neue Folge des Logos) Band 7, 133-45.

Krishna Deva

1960 Lakshmana Temple at Sirpur. in: Journal of the Madhya Pradesh Itihasa Parishad 2 (1960), 35-41.

Kropman, Martine

2008 The seals and inscriptions from Mansar. in: Bakker 2008, http://irs.ub.rug.nl/dbi/4ccec5f085aa0.

2018 The consecration of Kumāra: the role of Thanesar and King Harșa in the composition of the Skandapurāna. in: Journal of the Royal Asiatic Society, series 3 (2018), 1-31.

Krṣnakarṇāmṛta

(KK) The Krșnakarnāmrta edit. by S.K. De. Dacca 1938. University of Dacca Oriental Publication Series No. 5.

Bilvaman்gala's Kṛ̦ṇa-Stotra. Edit. by Maheshwar Neog. Gauhati 1962. See Wilson 1975.

Kșīrasvāmin

The Kṣ̄ratarañgiṇ̄. Kșīrasvāmin's Kommentar zu Pāṇini's Dhātupāṭa. Zum ersten Mal herausgegeben von Bruno Liebich. Breslau 1930. Indische Forschungen Doppelheft 8/9. 
Kuiper, F.B.J.

1983 Ancient Indian Cosmogony. Essays selected and introduced by John Irwin. Delhi.

Kulke, Hermann

1978 Royal Temple Policy and the Structure of Medieval Hindu Kingdoms. in:

Eschmann, A. et al. (eds.) 1978. pp. 125-37.

1998 Geschichte Indiens. Zweite, verbesserte und aktualisierte Auflage, München 1998.

Kulke, H \& D. Rothermund

1982 Geschichte Indiens. Stuttgart etc. 1982.

Kūrmapurāṇa

(KūP) The Kūrmapurāna, crit. edit. by Anand Swarup Gupta. Varanasi 1971.

All-India Kashiraj Trust.

Lacey, Harriet Ruth

2016 Rāmțek and its landscape: An archaeological approach to the study of the Eastern Vākāțaka Kingdom in Central India. Durham University, Durham. 2 vols. (Thesis)

Laksmīdhara

Krtyakalpataru

(TVK) Aștamo bhāgah. Tịrthavivecanakāndam, edit. by K. V. Rangaswami Aiyangar. Baroda 1942. Gaekwad's Oriental Series XCVIII.

Langlois, A.

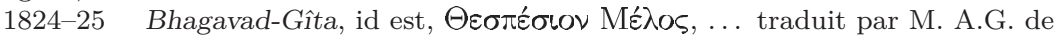
Schlégel. (Critique Littéraire). in: Journal Asiatique IV (1824), 105-116, 236-252; V (1824), 240-252; VI (1825), 232-250.

1826 Lettre adressée à M. le président du Conseil de la Société Asiatique. in: Journal Asiatique IX (1826), 186-189.

Law, B.C.

1943 Ayodhyā in ancient India. in: Journal of the Ganganatha Jha Research Institute I (1943), 423-443.

Lawrence, B. Bruce

1978 Notes from a Distant Flute. The Extant Literature of pre-Mughal Indian Sufism. Tehran.

1990 Defenders of God. The Fundamentalist Revolt against the Modern Age. London/New York.

Lefèvre, Vincent

2006 Commanditaires \& artistes en Inde du Sud. Des Pallava aux Nāyak

(VIe-XVIIIe siècle). Presses Sorbonne Nouvelle, Paris.

Lévi, Sylvain

1915 Le Catalogue géographique des Yakșa dans la Mahāmāyūrī. in: Journal asiatique, Série 11, t. V (1915), 19-138.

1929 [Review of the Crit. Ed. of the MBh] in: Journal Asiatique CCXV (1929) 345-48.

1934 [Review of the Crit. Ed. of the MBh] in: Journal Asiatique CCXXIV (1934), 281-83.

Liber Sancti Jacobi

Codex Calixtinus Vol. I: Texto, transcripcion de Walter M. Whitehil.

Santiago de Compostela 1944.

Lienhart, Siegfried

1984 A history of classical poetry: Sanskrit-Pali-Prakrit. Wiesbaden. A History of Indian Literature, Vol. III, fasc. I. 
Lingapurāṇa

(LiP) Śrī-Vyāsa-maharșiproktam Śrī-Lingamahāpurāṇam, with the Sanskrit commentary Śivatoṣin̄ī by Gaṇeśa Nātu. [Edit. by] Gañgāviṣnu (son of Krṣnadāsa). Venkatesvara Press, Bombay V.S. 1981 [= AD 1924]. [Reprinted, with a Ślokānukramaṇī by Nāgaśaraṇa Siṃha, by Nag Publishers, Delhi 1989 (2nd ed. 1996)]

((LiP Vañg. Ed.) The Lingapurāṇa [of] Kṛ̣ṇa Dvaipāyana Vyāsa. [Edit. by] Pañcānana Tarkaratna. Vañgavāsī Press, Calcutta 1297 [= AD 1890].

Lingat, Robert

1967 Les sources du droit dans le système traditionel de l'Inde. Paris-La Haye. Long, Bruce J.

1971 Siva as promulgator of traditional learning and patron deity of the fine arts. in: ABORI 52 (1971), 67-80.

Lord, A.B.

1960 The Singer of Tales. Cambridge (Mass.).

Lorenzen, David N.

1972/1991 The Kāpālikas and Kālāmukhas. Two lost Śaivite sects. New Delhi 1972. Second revised edition, Delhi 1991.

1978 Warrior ascetics in Indian history. in: Journal of the American Oriental Society 98.1 (1978), 61-75.

1978 Warrior Ascetics in Indian History. in: JAOS 98 (1978), 61-75.

Lüders, Heinrich

1961 Mathurā Inscriptions. Unpublished papers edited by Klaus L. Janert.

Göttingen. Abh. d. Ak. d. Wiss. in Göttingen. Phil.-hist. Kl. 3. Folge, Nr. 47.

Lutzker, Mary-Ann

1984 The Celebration of Arjuna. The Kiratarjuniya and the Arjunawiwaha in South and Southeast Asian Art. University of California, Berkeley (thesis).

McCrindle, J.W.

1877 Ancient India as described by Megasthenes and Arrian.

McGregor, R.S. Calcutta-Bombay-London.

1984 Hindi Literature from its Beginnings to the Nineteenth Century. Wiesbaden. A History of Indian Literature Vol. VIII Fasc. 6.

Mahābhārata

(MBh) The Mahābhārata. For the first time critically edited by V. S. Suktankar and others. Poona 1927-59. 19 vols.

(MBhB) The Mahābhārata with the Bhāratabhāvadīpa by Nīlakaṇtha, edit. by Kinjawadekar, Ramachandrashastri. Chitrashala Press, Poona 1929-36. 7 vols. [reprinted, New Delhi 1979]

The Mahābhārata. Translated and Edited by J.A.B. van Buitenen. Volume 2: 2 The Book of the Assembly Hall; 3 The Book of the Forest. Chicago and London 1975.

Mahadevan, T.M.P.

1980 The Hymns of Śankara. Delhi.

Mahajan, Malati

2000 Chhattisgarh. A Study in the Culture and Historical Geography (from Place Names in Inscriptions). Delhi.

Mahāvastu

Le Mahāvastu. Texte sanscrit publié pour la première fois et accompagné d'introduction et d'un commentaire par É. Senart. Paris 1882-1897. Reprint, Tokyo 1977. 3 vols.

Māheśvarakhanda

(MKh Ven̉k. Ed.) The Māheśvarakhanḍa of the Skandapurāṇa (SkP), Vol. 1. [Edit. by] Kșemarāja. Bombay 1910. 
(MKh Vañg. Ed.) Skandapurāṇam, Māheśvarakhaṇdam. [Edit. by] Śrīyukta Pañcānana Tarkaratna. [With a Bengali translation by] Śrī Tārākānta Devaśarma Kāvyatīrtha. Vangavāsī Press, Bombay 1318 [= AD 1911].

Majer, Fr.

1798 Zur Kulturgeschichte der Völker. Historische Untersuchungen. Mit einer Vorrede von Herrn Vice-Präsident Herder in Weimar. Leipzig. 2 Bde.

Majumdar, N.G.

1920 The Muṇdeśvarī Inscription of the Time of Udayasena: The Year 30. in: Indian Antiquary XLIX (1920), 21-29.

1935-37 Explorations at Lauriya-Nandangarh. in: IAS, Annual Report 1935-36, 55-66. Excavations at Lauriya Nandangarh. in: IAS, Annual Report 1936-37, 47-50.

Majumdar, R.C.

1971 History of Ancient Bengal. Calcutta.

Majumdar, R.C. \& A.S. Altekar

1967 The Vākāttaka-Gupta Age: circa AD 200-500. Delhi.

Majumdar, R.C. et al. (eds.)

(HCI) The History and Culture of the Indian People. Bombay 1951-77. 11 vols. Bharatiya Vidya Bhavan.

1954 The Expansion and Consolidation of the Empire. Chapter III of 'The Classical Age'. The History and Culture of the Indian People III. Bombay.

Majumdar, Susmita Basu

2007 Re-editing the Junwani Copper Plate Inscription of Mahāśivagupta Bālārjuna, Regnal Year 57. in: Bhattacharya, Gouriswar et al. (eds.), Kalhār: Studies in Art, Iconography, Architecture, and Archaeology of India and Bangladesh. New Delhi. pp. 286-295.

Malamoud, Charles

1982 Les morts sans visage. Remarques sur l'idéologie funéraire dans le brâhmanisme. in: Gnoli, Gherardo \& Jean-Pierre Vernant, La mort, les morts dans les sociétés anciennes. Cambridge etc. pp. 441-453.

1999 Modèle et réplique. Remarques sur le paradigme du sacrifice humain dans l'Inde védique. in: Archiv für Religionsgeschichte 1 (1999), 27-40.

Mānavaśrautasūtra

(MŚS) The Mānava Śrautasūtra belonging to the Maitrāyaṇī Saṃhitā edit. by Jeannette M. van Gelder. New Delhi 1961.

Mann, Thomas

1952 Der Zauberberg. Fisher Verlag, Frankfurt 1952 (reprint 1996).

Mārkạ̣deyapurāṇa

(MkP) The Mārkaṇdeyamahāpurāṇam edit. (with a Hindi translation) by R.N.

Śarmā. Venkatesvara Steam Press, Bombay 1910. Reprinted with an

Ślokānukraman̄ī by N. S. Siṃha. Nag Publishers, Delhi 1983.

(Mārkpur.) The Márcaṇdeya Puráṇa in the original Sanscrit edited by K. M. Banerjea. Calcutta 1855-62. Bibliotheca Indica 29. [Reprinted by Biblio Verlag, Osnabrück 1988]

Marshall, J.P.

1970 The Britisch Discovery of Hinduism in the Eighteenth Century. Edit. by P.J.

Marshall. Cambridge. The European Understanding of India.

Martin, Montgomery

1838 The History, Antiquities, Topography, and Statistics of Eastern India. Volume I, Behar (Patna City) and Shahabad. London. Indian Reprint, Delhi 1976.

Matanga

Mataṅgapārameśvarāgama (Vidyāpāda) avec le commentaire de Bhatța

Rāmakaṇtha. Edition critique par N.R. Bhatt. Pondichéry 1977. Publications de l'Institut Français d'Indologie No. 56. 
Matsyapurāṇa

(MtP) Śrīmad-Dvaipāyanamuni-pran̄ītạ̣ Matsyapurāṇam, etad pustakam Ānandāśramasthapanditaih samśodhitam. [Poona] 1981. Ananda Ashrama Sanskrit Series 54. [Reprint of the ed. of H. N. Apte AD 1907]

Mauss, M.

1980 Sociology and Psychology. Essays translated by Ben Brewster, London.

Mayamata

Traité Sanskrit d'Architecture. Première Partie Ch. I à Xxv. Deuxième Partie Ch. XXVI - XXXvi et Index-Glossaire général. Édition Critique, Traduction et Notes par Bruno Dagens. Pondichéry 1970-76. Publications de l"Institut Français d'Indologie No. 40.1-2.

Mayrhofer, Manfred

(EWA) Etymologisches Wörterbuch des Altindoarischen. Heidelberg 1992-2001. 3 vols. Indogermanische Bibliothek II. Reihe: Wōrterbücher.

(KEWA) Kurzgefaßtes etymologisches Wörterbuch des Altindischen. Heidelberg 1956-1980. 4 vols. Indogermanische Bibliothek II. Reihe: Wōrterbücher.

Mead, George Herbert

1964 On Social Psychology. Selected Papers edited and with an Introduction by Anselm Strauss. Chicago/London.

1982 The Individual and the Social Self: unpublished work of George Herbert Mead. Edited with an Introduction by David L. Miller. Chicago.

Medieval Indian palaeography

(Med. Ind. Pal.) Medieval Indian Palaeography. Nagri Western and Southern India, edit. by Parmeshwari Lal Gupta. New Delhi 1984. Medieval Indian Palaeography II. Meister, Michael W.

1984 Discourses on Śiva. Proceedings of a Symposium on the Nature of Religious Imagery. Edited and with an Introduction by - -. Vakils, Feffer \& Simons, Bombay.

1984a Ś Siva's Forts in Central India: Temples in Dakșina Kosala and their "Daemonic" Plans. in: Meister M.W. (ed.), Discourses on Śiva. Bombay. pp. 119-142.

Mertens, Annemarie

1998 Der Dakșamythus in der episch-purāṇischen Literatur. Beobachtungen zur religionsgeschichtlichen Entwicklung des Gottes Rudra-Śiva im Hinduismus. Wiesbaden. Beiträge zur Indologie Band 29.

Meulenbeld, Gerrit Jan

1974 The Mādhavanidāna and its chief commentary. Chapters 1 - 10. Introduction, translation and notes. Leiden.

Michell, George

1990 Monuments of India. Volume One. Buddhist, Jain, Hindu. Harmondsworth. The Penguin Guide to the Monuments of India.

Miller, Barbara Stoler

1992 The Powers of Art. Patronage in Indian Culture. Edit. by - -. OUP, Delhi. Mirashi, Vasudev Vishnu

1954 Pravarapura, an Ancient Capital of the Vākātakas. in: Sarūpa Bhāratī or the Hommage of Indology being Dr. Lakshman Sarup Memorial Volume.

Hoshiapur. pp. 1-9.

1959 Meghadūta mẽ Rāmagiri arthāt Rāmțek. Nagpur. Vidarbha Saṃśodhana Mạ̣dala, No. 12.

1960 Studies in Indology. Vol. I. Nagpur.

1963 See CII V.

1964a Ramagiri of Kalidasa. in: Journal of Indian History, XLII.1 (1964), 131-43.

1964b Trivikrama, the author of Madālasācampū. in: Nagpur University Journal (Humanities), XV.1 (1964), 1-7. 
1966 A pillar inscription of Mahākshatrapa Rupiamma from Pawni. in: Mirashi, V.V, Studies in Indology Vol. IV. Varanasi. pp. 109-111. [appeared earlier in the Nagpur University Journal XVI, $1 \mathrm{ff}$.]

1980 Bhitari Stone Inscription of Skandagupta. in: Journal of the Epigraphical Society of India VII (1980), 86-92.

1982 Indological Research Papers (IRP). Vol. I. Nagpur.

1982a New light on a period in Gupta history. in: V.V. Mirashi, Indological Research Papers Vol. I, 65-77.

1982b The Rāmagupta Problem Re-examined. in: V.V. Mirashi, Indological Research Papers Vol. I, Nagpur. pp. 56-62.

Mirashi, V.V. \& L.R. Kulkarni

1939-40 Ramtek Stone Inscription of the Time of Ramachandra. in: EI XXV, 7-20. Mirnig, Nina

2016 Early Layers of Śaivism in the Kathmandu Valley: Śivalinga Pedestal Inscriptions from 466-645 CE. in: IIJ 59 (2016), 309-362.

Mishra, Ratan Lal

2003 Memorial Monuments in Ancient and Medieval India. Delhi. [Earlier published in 1991 with the title The Mortuary Monuments in Ancient and Medieval India].

Mishra, R.N.

1981 Sculptures in Dakshina Kosala (a brief survey of stylistic transformations, chronology and artisans). in: Chhavi 2. Krishnadasa Felicitation Volume. Banaras. pp. 139-143.

Mishra, Sudhekar Nath

1992 Gupta Art and Architecture (with special reference to Madhya Pradesh). Delhi.

Mitra, Debala

1971 Buddhist Monuments. Calcutta.

1984 Lakulı̄śa and Early Śaiva Temples in Orissa. in: Michael W. Meister (ed.), Discourses on Śiva. Philadelphia. pp. 103-118.

Monachus, Robertus

1866 Historia Iherosolimitana Roberti Monachi. L.ii De Laude urbis Iherosolimitanae. in: Receuil des historiens des croisades. Historiens Occidentaux III. Paris.

Mrgendrāgama

(MṝA Kr.) Kriyāpāda et Caryāpāda avec le commentaire de Bhațta-Nārāyaṇakaṇtha. Edition critique par N. R. Bhatt. Pondichéry 1962. Publications de l'Institut Français d'Indologie No. 23

Mujeeb, M.

1967 The Indian Muslims. London.

Mus, Paul

1975 India seen from the East: Indian and indigenous cults in Champa. Centre of Southeast Asian Studies, Monash University. Monash Papers on Southeast Asia 3.

Nagpur Gazetteer

1908 Central Provinces District Gazetteers: Nagpur District. Vol. A, Descriptive. Edit. by R.V. Russell. Bombay.

Narain, A.K.

1983 Religious Policy and Toleration in Ancient India with Particular Refrence to the Gupta Age. in: Smith, Bardwell L. (ed.), Essays on Gupta Culture. Delhi. pp. $17-51$.

Nārāyaṇabhaț̣a

Tristhalīsetuḥ [edit. by] Gaṇeśa Śāstrī Gokhale and published by Hari

Nārāyana Āpte. Punyākhyapattana (Poona) 1915.

Ānandāśramasamskṛtagranthāvali 78. 
Neuß, Jürgen

2003 The Temple of Mundeśvarī: Reconsidering the Evidence. in: Berliner Indologische Studien 15/16/17 (2003), 531-585.

2012 [Review of] Bakker, H.T. \& H. Isaacson, 'The Skandapurāna Volume II a'. in: Orientalistische Literaturzeitung 107 (2012), 55-57.

Nicholson, R.A.

1963 The Mystics of Islam. London (first published in 1914).

1964 The Idea of Personality in Sufism. Three lectures delivered in the University of London. Lahore (reprint).

Nigam, L.S. (ed.)

2000 Riddle of Indian Iconography (Zetetic on Rare Icon from Tālā). Delhi.

2004 Impact and Extension of Vākāțaka Art in Chhattisgarh (Dakșina Kosala). in: Bakker, Hans T. (ed.), The Vākātaka Heritage. Indian Culture at the Crossroads. Groningen 2004. pp. 143-156.

Niśvāsamukha

See Kafle 2015.

Niśvāsatattvasamhitā

(NiTS) The Niśvāsatattvasaṃhitāa, the earliest surviving Śaiva Tantra. Volume I: A critical edition \& annotated translation of the Mūlasūtra, Uttarasūtra \& Nayasūtra. Edited by Dominic Goodall in collaboration with Alexis Sanderson \& Harunaga Isaacson. With contributions of Nirajan Kafle, Diwakar Acharya \& others. Institut Français de Pondichéry, École Française d'Extrême-Orient, Asien-Afrika-Institut, Universität Hamburg. Pondichéry 2015. Collection Indologie 128, Early Tantra Series 1. [See also Kafle 2015] Guhyasūtra. Electronic text. Transcribed by Dominic Goodall and, for chapters 10-16, by Dominic Goodall and Diwakar Acharya from the palm-leaf Nepalese MS No.1-127, NGMPP A 41/14.

Niyogi, R

1949 The Praśasti Sections of the Candrāvatī Grants of VS 1150 and 1156. in: Indian Historical Quarterly 25 (1949): 31-37.

1959 The History of the Gāhadiavāla Dynasty. Calcutta.

Norman, K.R.

1991 Studies in the Minor Rock Edicts of Aśoka [= review of P.K. Andersen 1990]. in: Journal of the Royal Asiatic Society, 3rd Series, Vol. 1.2 (1991), 243-53.

Noth, Albrecht

1966 Heiliger Krieg und Heiliger Kampf in Islam und Christentum. Beiträge zur Vorgeschichte und Geschichte der Kreuzzüge. Bonn. Bonner Historische Forschungen 28.

Oberhammer, Gerhard

1977 Strukturen yogischer Meditation. Wien. Österreichische Ak. d. Wiss. Phil.-hist. Kl. Sitzungsberichte. 322. Band. Veröffentlichungen d. Komm. für Sprachen u. Kulturen Südasiens Heft 13.

1984 Wahrheit und Transzendenz. Ein Beitrag zur Spiritualität des Nyāya. Wien. Österreichische Ak. d. Wiss. Phil.-hist. Kl. Veröffentlichungen der Kommission für Sprachen und Kulturen Südasiens, Heft 18.

Oberlies, Thomas

2000 Kriegslisten und ungeziemendes Benehmen: Die Askesepraktiken der Pāśupatas. in: Tsuchida, Yutaro \& Albrecht Wezler (eds.), Harānandalaharī. Volume in Honour of Professor Minoru Hara on his Seventieth Birthday. Reinbek 2000, 175-191.

2003 A Grammar of Epic Sanskrit. Berlin/New York. Indian Philology and South Asian Studies 5. 
Obeyesekere, Gananath

1981 Medusa's Hair. An essay on Personal Symbols and Religious Experience. Chicago and London.

O'Flaherty, Wendy

1973 Asceticism and Eroticism in the Mythology of Śiva. London.

Oldenberg, Hermann

1886-92 The Grihya-Sûtras. Rules of Vedic Domestic Ceremonies translated by - - .

Part I Sânkhâyana-grihya-sûtra, Âsvalâyana-grihya-sûtra,

Pâraskara-grihya-sûtra, Khâdira-grihya-sûtra. Part II Gobhila, Hiranyakesin, Âpastamba. Âpastamba, Yagña-paribhâshâ-sûtras translated by F. Max Müller. Oxford. The Sacred Books of the East XXIX, XXX.

Oldham, C.E.A.W. (ed.)

1926 Journal of Francis Buchanan kept during the survey of the district of Shahabad in 1812-13. Patna.

Olivelle, Patrick

1999 Dharmasūtras. The law codes of Āpastamba, Gautama, Baudhāyana, and Vasistha. Translated from the Original Sanskrit and Edited by Patrick Olivelle. Oxford 1999. Oxford World's Classics.

Oppenberg, H.

1965 Quellenstudien zu Friedrich Schlegels Uebersetzungen aus dem Sanskrit. Marburg.

Oral Poetry

Das Problem der Mündlichkeit mittelalterlicher epischer Dichtung.

Herausgegeben von Norbert Voorwinden und Max de Haan. Darmstadt 1979.

Padmapurāna Wege der Forschung Bd. 555.

(PdP) Śrī Pādmaṃ Mahāpurāṇam, [edit. by ] Kṣemarāja śrī-Kṛ̣ṇadāsa and Gañgāviṣnu Śrīkrṣṇadāsa. Venkatesvara Press, Bombay V.S. 1984 (AD 1927) 3 vols. [Reprinted by Nag Publishers, Delhi 1984 (2nd ed. 1996). Vol. 4, Ślokānukramaṇ̄ by Nāgaśaraṇa Siṃha. Nag Publishers, Delhi $\left.1984\left(1996^{2}\right)\right]$.

Palmer, Andrew

1991 De overwinning van het kruis en het probleem van de christelijke nederlaag:

Kruistochten en djihaad in Byzantijnse en Syrisch-orthodoxe ogen. in: Bakker \& Gosman 1991, pp. 84-109.

Panigrahi, K.C.

1956 The Archaeological Remains at Benisāgar in the Singbhum District of Bihar. in: The Journal of the Bihar Research Society 42/1, 3-11.

Pānini

(P) The Vyākaraña-Mahābhāṣya of Patañjali, edited by F. Kielhorn. 3rd edition, revised and furnished with additional readings, references and select critical notes by K.V. Abhyankar. Poona 1962-72. 5 vols.

http://gretil.sub.uni-goettingen.de/gretil/1_sanskr/6_sastra/1_gram/ pmbhassu.htm : Patañjali: Vyākaraṇamahābhāṣya. Based on the edition by Franz Kielhorn (Bombay 1880-1885), revised by K.V. Abhyankar (Poona 1972-1996). Input by George Cardona (accessed 29-6-2016).

Paramānanda-Sāgara

Paramānanda-Sāgara. Edit. by Prabhūṣaṇa Śarmā, Kaṇṭamaṇi Śastrī, and Gokulānanda Tailañg. Kankroli VS 2016.

Pāraskaragṛhyasūtra

(PārGS) Gṛhyasūtrāṇi. Indische Hausregeln. Sanskrit und Deutsch herausgegeben von Adolf Friedrich Stenzler. II. Pâraskara. Leipzig 1878. Abhandlungen der Deutschen Morgenländischen Gesellschaft VI. Band No. 4.

Pargiter, F.E.

1913 The Purāna Text of the Dynasties of the Kali Age with Intr. and Notes. London etc. 
Parlier-Renault, Edith

2007 Temples de l'Inde méridionale. La mise en scène des mythes. Paris.

Parry, Milman

1971 The Making of Homeric Verse. The collected papers of Milman Parry. Edit. by Adam Parry. Oxford.

Pāśupatasūtra

(PS) The Pāśupatasūtra with the Pañcārthabhāṣya of Kaundinya. Edit. by R.

Ananthakrishna Sastri. Trivandrum 1940. TSS CXLIII.

Patañjali

Pathak, V.S

See s.v. Pāṇini.

1960 History of Śaiva Cults in Northern India from Inscriptions (700 A.D. to 1200

A.D.). Varanasi.

Patil, D.R.

1982 The origin of Memorial Stones. in: Settar \& Sontheimer 1982, 47-58.

Paümacariya

The Paumacariyam with Hindi translation, edit. by H. Jacobi. Sec. ed. rev. by Punyavijayati. Transl. into Hindi by Shantilal M. Vora. Varanasi 1962-1968, 2 vols. Prakrit Text Society Series Nos. 6, 12.

Petech,Luciano

1976 Indien bis zur Mitte des 6. Jahrhunderts. in: Propyläen Weltgeschichte 2. Bd.,

2. Halbbd. Frankfurt/Berlin/Wien. Ullstein Taschenbuchausgabe.

Pinch, William R

2006 Warior Ascetics and Indian Empires. Cambridge University Press, Cambridge.

Pingree, David

1970-81 Census of the exact sciences in Sanskrit. Series A, Vols. 1-4. Philadelphia.

Memoirs of the American Philosophical Society Vols. 81, 86, 111, 146.

Potter, Karl H. (ed.)

1981 Encyclopedia of Indian Philosophies. Volume III: Advaita Vedānta up to

Śamkara and his pupils. Delhi-Varanasi-Patna.

Pratima-kosha

1990 Encyclopaedia of Indian Iconography, Volume Three, [by] S.K. Ramachandra

Rao. Bangalore 1990. Kalpatharu Research Academy Publication.

Priolkar, Anant Kakba

1958 The Printing Press in India. Its beginnings and early development being a quartercentenary commemoration study (of the Advent of Printing in India in 1556). With a Foreword by Ch.D. Deshmukh, and an historical essay on the Konkani Language by J.H. da Cunha Rivera, translated from the Portugese by Th. Lobo. Bombay.

Proust, Marcel

1954 A la recherche du temps perdu, texte établi et présenté par Pierre Clarac et

André Ferré. Paris. 3 vols. Bibliothèque de la Pléiade 100, 101, 102.

Ptolemaeus, Claudius

Claudii Ptolemaei Geographia. Edidit C.F.A. Nobbe cum introductione a

Aubrey Diller, Leipzig 1843-1845.

Purāna Pañcalakșana

(PPL) see Kirfel 1927

Rad, G. von

1952 Der heilige Krieg im alten Israel. Göttingen.

Raghavan, V

1963 Bhoja's Śrñgāra Prakāśa. Madras.

Raghunātha Prasāda

Śrīmahārājacaritra. Bindu ācārya dīnabandhu śrīsvāmī Rāmaprasāda jī

Mahārāja kī sampūrṇa jīvan̄̄. [Edit. by] Rāmamanohara Prasādācārya.

Ayodhyā 1930. 
Rāmacandra Kaulācāra

Ramachandran, T.N.

Śilpaprakāśa see Boner \& Śarmā 1966.

1951-52 Aśvamedha Site near Kalsi. in: Journal of Oriental Research Madras

(Kuppuswami Sastri Research Institute, Mylapore), 21 (1951-52), 1-31.

Rāmāyana

(Rām.) The Vālmīki-Rāmāyana. Crit. edit. for the first time by a board of editors. Baroda 1960-75. 7 vols.

Ramesh, K.V. \& S.P. Tewari

1990 A Copper-Plate Hoard of the Gupta period from Bagh, Madhya Pradesh. New Delhi. Archaeological Survey of India.

Rāmottaratāpan̄ya Upaniṣad

(RUTU) Die Râma-Tâpanîya-Upanishad. Von A. Weber. Berlin 1864. Abhandlungen der königlichen Akademie der Wissenschaften zu Berlin. Philologische und historische Abhandlungen.

Rao, Gopinath T.A.

1914 Elements of Hindu Iconography. Madras. [Reprinted by Paragon Book Reprint Corp., New York 1968 in 2 volumes, 4 parts.]

Rao, Lakshman K.V.

1924 The Telugu Academy Plates of Vishṇukuṇdin = Mādhavavarman III. A.D. 594. in: Journal of the Department of Letters, University of Calcutta Vol. XI (1924), 31-62.

Rasārṇava

Rasārṇam or Rasatantram. A semi dialogue between Pārvatī \& Parameśvara. Edit. with Rasacandrika Hindi Commentary by Indradeo Tripathi. Varanasi 1978.

Raven, Ellen M.

1994a Gupta Gold Coins with a Garuda-Banner. Samudragupta-Skandagupta. Groningen. 2 vols. Gonda Indological Studies I.

1994b Invention and Innovation. Royal Gupta Gold Coins. in: Carter, Martha L. (ed.), A Treasure of Indian Coins. Marg Publications, Bombay 1994. pp. 39-56.

2004-05 A Ring for a King. in: Journal of Bengal Art 9/10 (2004-05), 71-88.

Ray, Amita

1960 House-Building Rituals in Ancient India. in: J.N. Banerjea Volume. Calcutta. pp. $298-312$.

Raykwar, G.L.

1989 Bilāspur jile k̄̄ Śaiv pratimāem. in: Purātan VI (1989), 187-188.

Raykwar, G.L. \& Rahul Kumar Singh

1994 Mahāśivagupta Bālārjuna kā 57 vem rājya varṣa kā Junavān̄̄ (Malhār) tāmralekha. in: Purātana 9 (1994), 146-47.

2005 Utkīrṇa Lekha. Lekhana evaṃ saṃpādana: Bālacandra Jain. Parivardhana: G.L. Rāyakavāra \& R.K. Siṃha. Raipur.

Renou, Louis

1925 La géographie de Ptolémée: l'Inde (VII, 1-4), texte établi [et trad. du Grec] par Louis Renou. Paris 1925 (thèse).

Rgveda

(RV) Hymns of the Rig-Veda in the Samhita and Pada texts. Reprinted from the Editio Princeps by F. Max Müller. Varanasi 1965. 2 vols.

Rhys Davids, T.W.

1903 Buddhist India. London. The Story of the Nations Vol. 61.

Riesebrodt, Martin

1990 Fundamentalismus als patriachalische Protestbewegung. Amerikanische

Protestanten (1910-28) und iranische Schiiten (1961-79) im Vergleich.

Tübingen. 
Risbud, A.K.

1984 Tālā Gāṃv kā Śiv-Mandir. in: Purātan I (1984), 58-61.

Rizvi, S.A.

1978 A History of Sufism in India. New Delhi. 2 vols.

Rocher, Ludo

1986 The Purānas. Wiesbaden. A History of Indian Literature Vol. II, Fasc. 3.

Rosenfield, John M.

1993 The Dynastic Arts of the Kushans. Indian Edition, Delhi.

Rosenkranz, Karl

1844 G.W.F. Hegels Leben. Berlin. (Darmstadt $1972^{2}$ ).

Roth, Gustav

1980 Symbolism of the Stūpa. in: Dallapiccola, Anna Libera (ed.), The Stūpa. Its

religious, historical and architectural significance. Wiesbaden. pp. 183-209.

Rüping, Klaus

1970 Amrtamanthana und Kūrma-Avatāra. Wiesbaden. Schriftenreihe des

Südasien- Instituts der Universität Heidelberg.

1977 Zur Emanationslehre im Mokșadharma. in: Studien zur Indologie und Iranistik 3 (1977), 3-10.

Russell, R.V.

1969 The Tribes and Castes of the Central Provinces of India. Oosterhout.

(Reprint of the 1916 edition). 4 vols.

Ruyter, Martin

1984 En hier kocht tante Léonie haar Madeleines. in: de Volkskrant, d.d. 25 mei 1984 .

Sahai, Bhagwant

1975 Iconography of Minor Hindu and Buddhist Deities. New Delhi.

Saindon, Marcelle

2000 Cérémonies funéraires et postfunéraires en Inde: la tradition derrière les rites. Québec.

Salomon, Richard

1979 Tīrthapratyāmnāyāḥ: Ranking of Hindu Pilgrimage Sites in Classical Sanskrit Texts. in: ZDMG 129, Heft 1 (1979), 102-128.

1989 New Inscriptional Evidence for the History of the Aulikaras of Mandasor. in: IIJ 32 (1989),1-36.

1998 Indian Epigraphy. A Guide to the Study of Inscriptions in Sanskrit, Prakrit, and other Indo-Aryan Languages. Delhi.

Samgītaratnākara

Sāṃkhyakārikās

See Śārngadeva

(SK) Sāṃkhyakārikās of İ́varakṛ̣ṇa. With the Yuktidīpikā and the Sanskrit Commentary Tattvaprabhā and Hindi gloss by Ramāśankara Tripāthi. Vārānas̄i 1970.

Sāṃkhyasūtras

(SS) The Sāmkhya-pravacana-bhāsya or commentary on the exposition of the Sānkkhya philosophy. Edit. by Richard Garbe. Cambridge (Mass.) 1943. Harvard Oriental Series 2.

Śamkara

(ad BhG) Śrīmadbhagavadgītā [with the commentary of] Śrīśamkara. [Edit. by] Ganeśa Śāstrī Jośī. Poona 1981. Ananda Ashrama Sanskrit Series 34.

Saṃyuttanikāya

The Samyutta-Nikâya of the Sutta-Pițaka, edit. by M. Léon Feer. London 1960 (reprint), 5 vols. Pali Text Society. 
Sanderson, Alexis

1985 Purity and power among the Brahmans of Kashmir. in: Carrithers, M. \& S. Collins \& S. Lukes (eds.), The Category of the Person. Anthropology, Philosophy, History. Cambridge. pp. 190-216.

1988 Śaivism and the Tantric Traditions. in: Steward Sutherland et alii (eds.), The World's Religions. London, 660-704.

2001 History through Textual Criticism in the Study of Śaivism, the Pañcarātra and the Buddhist Yoginītantras. in: Grimal, François (ed.), Les sources et le temps/Sources and Time. Pondichéry. pp. 1-47.

2003-04 The Śaiva Religion among the Khmers. Part I. in: Bulletin de l'École françcaise d'Extrême-Orient 90-91 (2003-04), 349-462.

2004 Religion and the State: Śaiva Officiants in the Territory of the King's Brahmanical Chaplain. in: IIJ 47 (2004), 229-300.

2006 The Lākulas: New Evidence of a System Intermediate between Pāñcārthika Pāśupatism and Āgamic Śaivism. in: The Indian Philosophical Annual 24 (2006), 143-217.

2009 The Śaiva Age: The Rise and Dominance of Śaivism during the Early Medieval Period. in: Einoo, Shingo (ed.), Genesis and Development of Tantrism. Tokyo 2009. pp. 41-350.

2013 The Impact of Inscriptions on the Interpretation of Early Śaiva Literature. in: IIJ 56 (2013), 211-44.

Sankalia, H.D.

1973 The Ur (original) Rāmāyana or Archaeology and the Rāmāyana. in:

Indologen-Tagung 1971, edit. by H. Härtel \& V. Moeller, Wiesbaden 1973, $153 \mathrm{f}$.

Sankaranarayanan, S.

1977 The Visnukundis and Their Times (An Epigraphical Study). Foreword T.V. Mahalingam. Delhi.

Śānkhāyanagṛhyasūtra

(ŚāṅGS) Das Çân̄khâyanagrihyam. [Edit. by] H. Oldenberg. in: Albrecht Weber (Hrsg.), Indische Studien XV, 1-166. Hildesheim 1973 (reprint).

Santoro, Arcangela

1980 Su tre bassorilievi Gandharici di soggetto non identificato. in: Rivista degli Studi Orientali LIV (1980), 97-110.

Sanyal, Niradbandhu

1935 The Proposed Identification of the 'Mother \& Child' Images as Sadyojāta. in: Proceedings and Transactions of the Seventh All-India Oriental Conference Baroda, December 1933. Baroda. pp. 775-779.

Sarkar, H.

1982 The Chāyā-stambhas from Nāgārjunakoṇḍa. in: Settar \& Sontheimer 1982, 199-207.

Sarkar, Jadunath.

1958 A History of Dasnami Naga Sanyasis. Allahabad.

Śārngadeva

Saromāhātmya

Samgītaratnākara. With Kalānidhi of Kalinātha and Sudhākara of Siṃhabhūpāla. Edit. by S.S. Sastri. Vol I (Adhyāya I). Madras 1943.

(VāmP) The Vāmana purāṇa. Crit. edit. by Anand Swarup Gupta. All-India Kashiraj Trust, Varanasi 1967. pp. 164-292.

Śāstri, Hirananda

1917-18 Haraha Inscription of the Reign of Isanavarman: [Vikrama Sambat] 611. in: EI XIV (1917-18), 110-120. 
Śatapathabrāhmaṇa

(ŚBr) The Çatapatha-Brâhmaṇa in the Mâdhyandina-Çâkhâ with extracts from the commentaries of Sâyana, Harisvâmin and Dvivedaganga edited by Albrecht Weber. Leipzig 1924. (Reprint, Varanasi 1964).

The Śatapatha-Brāhmaṇa according to the text of the Mādhyandina School, transl. by Julius Eggeling. Reprint, Delhi 1963. 5 vols. The sacred books of the East 12, 26, 41, 43, 44. (original ed. Oxford, 1882-1900).

Scheuer, Jacques

1982 Śiva dans le Mahābhārata. Paris. Bibliothèque de l'École des Hautes Études, Section des Sciences Religieuses Vol. LXXXIV.

Schimmel, A.

1980 Islam in the Indian Subcontinent. Leiden. Handbuch der Orientalistik, 2. Abt. 'Indien' 4. Bd. 3. Abschnitt.

Schlegel, August Wilhelm

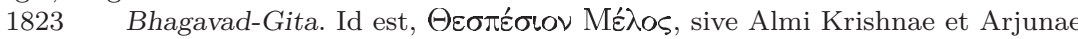

Colloquium de rebus divinis, Bharateae episodium. Textum recensuit, adnotationes criticas et interpretationem Latinam adiecit Augustus Guilelmus a Schlegel. Academia Borussica Rhenana Typis Regiis, Bonnae.

1826 Observations sur la critique du Bhagavad Gîtâ, insérée dans le Journal Asiatique (1). in: Journal Asiatique IX (1826), 3-27.

(Schlegel BhG) See Schlegel 1823.

Schlegel, Friedrich

1808 Ueber die Sprache und Weisheit der Indier. Ein Beitrag zur Begründung der Alterthumskunde. Heidelberg. [in: Sämmtliche Werke. 2. Original Ausgabe. 7.

Schlingloff, Dieter Band. Wien 1846. pp. 271-382.].

1968-69 Menschenopfer in Kauśāmbī? in: IIJ 11 (1968/69), 175-189.

1969 Die altindische Stadt. Eine vergleichende Untersuchung. Wiesbaden. Abh. d. Ak. d. Wiss. u. d. Lit. in Mainz, Geistes u. Sozialwiss. Kl.

Schmidt, Hanns-Peter

1968 The Origin of Ahimsāa. in: Mélanges d'Indianisme à la mémoire de Louis Renou. Paris. pp. 625-655.

1997 Ahimsā and Rebirth. in: M. Witzel (ed.), Inside the Texts - Beyond the Texts: New Approaches to the Study of the Veda. Cambridge (Mass.). pp. 207-234.

Schmithausen, Lambert

1999 Aspects of the Buddhist Attitude towards War. in: Houben, Jan E.M \& Karel R. van Kooij (eds.), Violence Denied. Violence, Non-Violence and the Rationalization of Violence in South Asian Cultural History. Leiden. pp. $45-67$.

Schoonenberg, P.

1978 Gott als Person und Gott als das unpersönlich göttliche. Bhakti und Jñāna. in: Oberhammer, Gerhard (ed.), Tranzendenzerfahrung. Vollzugshorizont des Heils. Wien. pp. 207-34.

Schopen, Gregory

1997 Bones, Stones, and Buddhist Monks. Collected Papers on the Archaeology,

Schreiner, $\mathrm{P}$. Epigraphy, and Texts of Monastic Buddhism in India. Honolulu.

1997 Nārāyaṇiya-Studien, herausgegeben von Peter Schreiner. Wiesbaden. Purāṇa Research Publications Tübingen vol. 6.

Schulin, E.

1958 Die weltgeschichtliche Erfassung des Orients bei Hegel und Ranke. Göttingen.

Schwab, Raymond

1950 La renaissance orientale. Paris. 
Select Inscriptions

Sen, Nabaneeta

ect Inscriptions bearing on Indian History and Civilization. See Sircar,

Dines Chandra (SI).

1966 Comparative Studies in Oral Epic Poetry and the Vālmīki Rāmāyaṇa: A report on the Bālākānda. in: JAOS 86 (1966), 397-409.

Settar, S. \& Gunther D. Sontheimer (eds.)

1982 Memorial Stones. A study of their origin, significance and variety.

Dharwad/Heidelberg. I.A.H. Series No. 2/South Asian Studies No. XI/11.

Shah, Priyabala

1984 Lakulı̄śa: Śaivite Saint. in: Meister 1984, 92-102.

See Viṣnudharmottarapurāṇa (VDhP III).

Sharfe, Hartmut

1989 The State in Indian Tradition. Leiden. Handbuch der Orientalistik. 2. Abt. 'Indien', 3. Band 'Geschichte', 2. Abschnitt.

Sharma, A.K.

2002 Excavations at Mansar and Sirpur-Flash. in: Purātattva 2002. Emerging Trends of Archaeology, Art, Anthropology, Conservation and History (in honour of Sri Jagatpati Joshi), edit. by A.K. Sharma \& R.S. Bist, pp. 801-09.

2009 Sculptural Art of Mansar. Bharatiya Kala Prakashan, Delhi.

Sharma, Govardhan Raj

1960 The Excavations at Kausāmbī (1957-59). The defences and the Śyenaciti of the Purusamedha. Allahabad. Institute of Archaeology, Allahabad University Publications No. 1.

Sharma, Meera

2017 Iconography and Sculptural Art: Documentation of Sculptures. in: Jayaswal 2017, 115-22.

Sharma, Ram Karan

1964 Elements of Poetry in the Mahābhārata. Berkeley.

Shastri, Ajay Mitra

1970 Some observations on the Hisse-Borala inscription of Vākātaka Devasena. in Proceedings of the Indian History Congress 31st Session 1969. Varanasi. pp. 47-55.

1977-78 Māṇdhal Utkhanana. in: Vidarbha Samśodhana Mạ̣dala Vārṣika 1977-78, $142-174$.

1984-86 Fresh epigraphic evidence on the Vākāṭakas. in: Nagpur University Journal 35 (1984-86), 130-64.

1987 Early History of the Deccan: Problems and Perspectives. Delhi.

1987a The Vākātakas. Fresh Epigraphic Evidence. in: Shastri, A.M., Early History of the Deccan. Delhi 1987. pp. 45-81.

1991 Varāhamihira and his times. Jodhpur.

1992 The Age of the Vākāṭakas. New Delhi.

1992a Balesvara - Bhattaraka. A hitherto unknown Saiva establishment at Sripura. in: Journal of the Epigraphical Society of India 18 (1992), 15-23.

1992b New Vākāttaka Inscriptions. in: A.M. Shastri (ed.), The Age of the Vākātakas. New Delhi. pp. 227-268.

1995 Inscriptions of the Śarabhapurīyas, Pāṇḍvaṃśins and Somavaṃśins. Delhi. 2 vols.

1997 Vākāttakas: Sources and History. New Delhi.

1998 The Sātavāhanas and the Western Kshatrapas. A historical framework. Nagpur.

2001 Malhar Plates of Mahāśivagupta, year 57. in: Bharatiya Purabhilekha Patrika (Studies in Epigraphy) XXVII (2001), 25-48. 
Shastri, A. M. \& Ch. Gupta

1997 Māṇhhal Plates of Vākātaka Rudrasena II, Year 5. in: Annals of the Bhandarkar Research Institute LXXVIII (1997), 143-157.

Shastri, A.M. \& K.D. Kawadkar

2001 Miregāon Plates of Prabhāvatī Guptā, Year 20. in: Annals of the BORI LXXXI (2001), 135-151.

Shastri, Haraprasad

1905-15 A Catalogue of Palm-leaf and Selected Paper MSs belonging to the Durbar Library, Nepal (to which has been added a Historical Introduction by C. Bendall). [Vol. I] Calcutta 1905. Vol. II, Calcutta 1915.

1928 A Descriptive Catalogue of Sanskrit Manuscripts in the Government Collection under the care of the Asiatic Society of Bengal. Vol. V, Purāna Manuscripts. Calcutta.

Shaw, Graham

1981 Printing in Calcutta to 1800. A description and checklist of printing in late 18th-century Calcutta. London.

Sindūragirimāhātmya

(SM) Sindūragirimāhātmya, edit. by S.M. Ayachit. Nagpur 1985.

Shrimali, Krishna Mohan

1983 History of Pañcāla: to c. AD 550. New Delhi. 2 vols.

1987 Agrarian Structure in Central India and the Northern Deccan c. AD 300-500: A study of Vākātaka inscriptions. New Delhi.

Simha, Bhagavati Prasad

1957 Rāmabhakti mẽ Rasika Sampradāya. Balarampur.

Singh, Arvind Kumar

2017 Palaeographic Records of Mundeshwari: Documentation of Inscriptions. in: Jayaswal et al. 2017, 17-114.

Singh, Jai Prakash

1989 Study of Local Coin Types of Mathurā with Particular Reference to Religious Motifs. in: Srinivasan 1989, 146-152.

Singh, Purushottam

1970 Burial Practices in Ancient India. A study in the eschatological beliefs of early man as revealed by archaeological sources. Varanasi. Indian Civilisation Series XVII.

Singh, Rahul Kumar

1989 Bilāspur jile ke prācīn Śiv Mandir. in Purātan VI (1989), 169-170.

Singh, Sheo Bahadur

1976 Dakșināmūrti Sculptures in Uttar Pradesh. in: Vishveshvaranand Indological Journal XIV (1976), 107-111.

Sinha, B.P.

1977 Dynastic History of Magadha. Cir. 450-1200 AD. New Delhi.

Sircar, Dines Chandra

(SI) Select Inscriptions bearing on Indian History and Civilization. Volume I, Calcutta 1942 [2nd ed.: Delhi/Madras 1965]. Volume II, Delhi 1983.

1953-54 Two Inscriptions of Gauri. in: Epigraphia Indica XXX (1953-54), 120-32.

1954 The Vākātakas. in: R.C. Majumdar (ed.), The Classical Age. (History and Culture of the Indian People Vol. III). Bombay. Vol. III, pp. 177-188.

1962 Copper coins of Rāmagupta. in: Journal of Indian History 40 (1962), 533-536.

1964 Maukhari Inscription from Jaunpur. in: Journal of Indian History XLII (1964), 127-130.

1966 Indian Epigraphical Glossary. Delhi.

Sircar, D. C. \& G.S. Gai

1961-62 Fragmentary Inscriptions from Chitorgarh. in: EI 34 (1961-62), 53-58. 


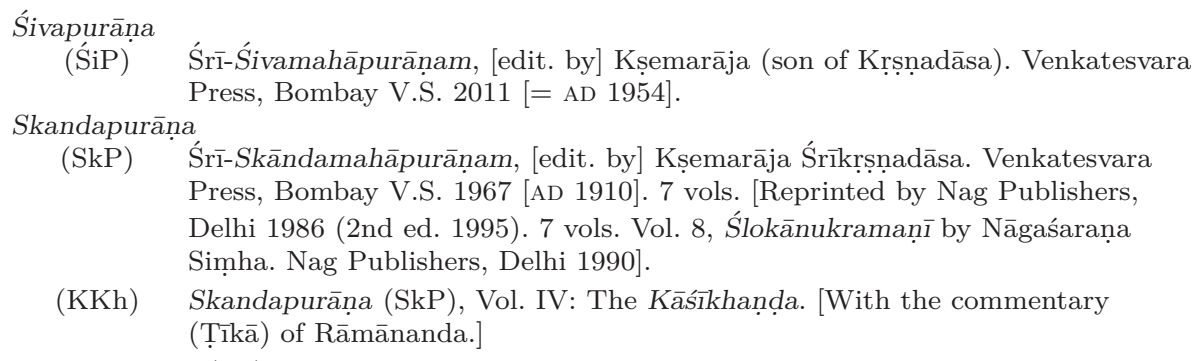

Skandapurāṇa (SP)

(SP I) The Skandapurāṇa, Volume I. Adhyāyas 1-25. Critically Edited with Prolegomena and English Synopsis by R. Adriaensen, H.T. Bakker \& H. Isaacson. Groningen 1998. Supplement to Groningen Oriental Studies.

(SP II A) The Skandapurāṇa, Volume II A. Adhyāyas 26-31.14: The Vārāṇasī Cycle. Critical Edition with an Introduction, English Synopsis \& Philological and Historical Commentary by Hans T. Bakker \& Harunaga Isaacson. Groningen 2004. Supplement to Groningen Oriental Studies.

(SP II B) The Skandapurāṇa, Volume II B. Adhyāyas 31 - 52: The Vāhana and Naraka Cycles. Critical Edition with an Introduction and Annotated English Synopsis by Hans T. Bakker, Peter C. Bisschop, Yuko Yokochi, in cooperation with Nina Mirnig and Judit Törzsök. Brill, Leiden/Boston 2014. Supplement to Groningen Oriental Studies.

(SP III) The Skandapurāna, Volume III. Adhyāyas 34.1-61, 53-69: The Vindhyavāsinī Cycle. Critical Edition with Introduction and Annotated English Synopsis by Yuko Yokochi. Forsten/ Brill, Groningen/Leiden 2013.

(SP IV) The Skandapurāṇa, Volume IV. Adhyāyas 70-95: Start of the Skanda and Andhaka Cycles. Critical Edition with an Introduction \& English Synopsis by Peter C. Bisschop and Yuko Yokochi, in cooperation with Diwakar Acharya and Judit Törzsök. Brill, Leiden/Boston 2018. Supplement to Groningen Oriental Studies.

(SP 167) [For edition of Adyāya 167 see Bisschop 2006.]

$\left(\mathrm{SP}_{\mathrm{Bh}}\right) \quad$ Skandapurāṇasya Ambikākhaṇdah sampādakah Kṛṣnaprasāda Bhatṭarāī. Kathmandu 1988. Mahendraratnagranthamālā 2.

Slusser, Mary Shepherd

1982 Nepal Mandala. A cultural study of the Kathmandu Valley. Vol. 1 Text, Vol. 2, Plates. Princeton. 2 vols.

Smith, Bardwell L. (ed.)

1983 Essays on Gupta Culture. Delhi etc. Smith, John D.

1977 The Singer or the Song? A reassessment of Lord's 'Oral Theory'. in: MAN 12 (1977), 141-153.

1980 Old Indian. The two Sanskrit Epics. in: Traditions of Heroic and Epic Poetry. London 1980. pp. 48-78.

Smith, Travis L.

2006 Lament for a 'living literature'. A philologist's field report on what ails Puranic Studies. in: Biblio. A Review of Books. Vol. XI Nos. 3 \& 4

(March-April 2006), 24-26.

2017 [Review of] 'The World of the Skandapurāna' by Hans T. Bakker. in: JRAS 2017, 523-24.

Sontakke, Virag \& Shrikant Ganvir \& Shantanu Vaidya \& P.P. Joglekar

2016 Excavation at Nagardhan, Nagpur District, Maharashtra (2015-2016). in: History Today 17 (2016), 43-51. 
Sontheimer, G.D.

1985 Folk Deities in the Vijayanagara Empire: Narasiṃha and Mallaṇna/Mailār. in: Dallapiccola, A.L. (ed.), Vijayanagara-City and Empire. New Currents of Research. Wiesbaden. pp. 144-59.

Speijer, J.S

1886 Sanskrit Syntax. Leiden.

Spink, Walter

1981 Ajanta's Chronology: politics and patronage. in: Williams, Joanna G. (ed.), Kalādarśana. New Delhi. pp. 109-26.

1983 The Great Cave at Elephanta: a Study of Sources. in: Smith, Bardwell L., Essays on Gupta Culture. Delhi, pp. 235-282.

Śrīnivāsadāsa

Yatīndramatadīpikā, edit. by H. N. Apte. Poona 1906. Ānanda Āśrama

Sanskrit Series No. 50.

Srinivasan, Doris Meth

1989 Mathurā. The Cultural Heritage. American Institute of Indian Studies. New Delhi.

1997 Many Heads, Arms and Eyes. Origin, Meaning and Form of Multiplicity in Indian Art. Leiden etc. Studies in Asian Art and Archaeology XX.

Srinivasan, P.R.

1991 Mundesvari Temple Inscription. in: Margabandhu, C. et al. (eds.), Indian Archaeological Heritage. Shri K.V. Soundara Rajan Festschrift. Vol. I. Delhi.

Srivastava, M.

1984 Sirpur. Bhopal.

Stadtner, Donald M.

1976 Sirpur to Rajim: the Art of Kosala During the Seventh Century. University of California, Berkeley 1976. [Unpublished PhD thesis].

1980 A Sixth-century A.D. Temple from Kosala. in: Archives of Asian Art 33 (1986), 38-48.

1981a Ancient Kosala and the Stellate Plan. in: Williams, J.G. (ed.), Kalādarśana, New Delhi. pp. 137-45.

1981b The Siddheśvara Temple at Palāri and the Art of Kosala during the Seventh and Eighth Centuries. in: Ars Orientalis 12 (1981), 49-56.

Stein, Burton

1969 Interpretation of the Agrarian System of South India. in: Frykenberg, R.E.

(ed.), Land Control and Social Structure in Indian History. Madison. pp. 175-216.

1978 All the King's Mana: Perspectives on Kingship in Medieval South India. in: Richards, J.F. (ed.), Kingship and Authority in South Asia.

Wisconsin-Madison. pp. 115-67.

1983 Mahānavamī: medieval and modern kingly ritual in South India. in: Bardwell L. Smith (ed.), Essays on Gupta Culture. Delhi. pp. 67-90.

1992 The Politicized Temples of Southern India. in: Bakker 1992, pp. 163-77.

Sternbach, Ludwik

1978-80 A descriptive catalogue of poets quoted in Sanskrit anthologies and

Sthānapothī inscriptions. Wiesbaden. 2 vols.

Sthāna Pothī. Prastāvanā, Mūla Pothī, Sthānasūcī, Kațhīṇa śabdāṃcā kośa, ityadīsahita sampādilelā. [Edit. by] Viṣnu Bhikājî Kolte. Malkapur 1976 (2nd ed.).

Sthānasūtra

See Abhayadeva Sūri 
Stietencron, Heinrich von

1979 Angst und Gewalt. Ihre Präsenz und ihre Bewältigung in den Religionen.

Düsseldorf.

Stolz, Fritz

1986 Religion zu Krieg und Frieden. Zürich.

Stuhr, P.

1812 Vom Untergange der Naturstaaten. Berlin.

Sumption, Jonathan

1975 Pilgrimage. An image of Mediaeval Religion. London.

Sūradāsa

Svacchandatantra

Sūrasāgara. Edit. by Nandadulāre Vājapeȳ̄. Kashi VS 2033-35 [= AD 1976-78] (5th printing).

(SvT) The Svacchandatantram with commentary Udyota by Kṣemarājācārya. Edit. by Vraj Vallabh Dwivedi. Delhi 1985. 2 vols.

(SvT (Bombay ed.)) The Swacchanda-Tantra with commentary [Udyota] by Ksemarāja. Edit. with notes by Madhusudan Kaul Shāstrī. Bombay 1921-1935. 6 vols. Kashmir Series of Texts and Studies Nos. XxXI, XxxvIII, XLIV, XLVIII, LI/LIII, LVI.

Śvetāśvatara Upaniṣad

(Śvet.Up.) in: V. P. Limaye \& R. D. Vadekar (eds.), Eighteen Principal Upaniṣads. Vol. I. Upanișadic Text with Parallels from extant Vedic Literature, Exegetical and Grammatical Notes. Poona 1958. Gandhi Memorial Edition.

Swamikannu Pillai \& L.D. Dewan Bahadur

1982 Indian Chronology (solar, lunar and planetary): a practical guide. The interpretation and verification of tithis, nakshatras, horoscopes and other Indian time-records B.C. 1 to A.D. 2000. New Delhi.

Taittirīyāranyaka

(TaiĀ) Taittirīyāraṇyakam. With the Commentary of Sāyaṇācārya. Edit. by Rājendralāl Mitra. Calcutta 1871. Bibliotheca Indica LII.

\section{Taittirīya-Samhitā}

(TaiSa) Taittirîya-Samhitâ, herausgegeben von Albrecht Weber. Leipzig 1871-72. 2 vols. Indische Studien. Beiträge für die Kunde des indischen Alterthums.

(TaiS transl.) The Veda of the Black Yajus school, entitled Taittiriya Sanhita. Transl. from the original Sanskrit prose and verse by Arthur Berriedale Keith. Cambridge (Mass.) 1914. 2 vols. Harvard Oriental Series 18, 19.

Takakusu, J.

1904 The Life of Vasubandhu by Paramārtha (AD 499-569). in: T'oung pao, Serie II, Vol. V (1904), 269-296.

Tandon, Pankaj

2014 The Succession after Kumāragupta I. in: Journal of the Royal Asiatic Society Series 3 (2014), pp. 1-16.

Tanemura, Ryugen

2004 Kuladatta's Kriyāsaṃgrhapañjikā. A critical edition and annotated translation of selected sections. Groningen. Groningen Oriental Studies XIX.

Tedesco, $\mathrm{P}$

1945 Sanskrit munda - 'Shaven'. in: JAOS 65 (1945), 82-98.

Thapar, Romila

1983 The Archaeological Background to the Agnicayana Ritual. in: Frits Staal (ed.), Agni II, 2-40.

Thaplyal, Kiran Kumar

1972 Studies in Ancient Indian Seals: a study of North Indian seals and sealings from circa third century BC to mid-seventh century AD. Lucknow.

1985 Inscriptions of the Maukharīs, Later Guptas, Puspabhūtis and Yaśovarman of Kanauj. Delhi. 
Tieken, Herman

1993 The So-Called Trivandrum Plays Attributed to Bhāsa. in: WZKSA 37 (1993), $5-44$.

Tīrthāink

T̄̄rthāṅk. in: Kalyāṇa 31 (1957), 1-704. (Gitapress Gorakhpur).

Tiwari, Jagdish Narain

1979 Disposal of the Dead in the Mahābhārata. A study in the Funeral Customs in Ancient India. Varanasi.

Tripathi, G.C.

1968 Der Ursprung und die Entwicklung der Vāmana Legende in der indischen

Literatur. Wiesbaden.

Tripathi, Rama Shankar

1964 History of Kanauj to the Moslem Conquest. Delhi.

Triṣaștiśalākāpuruṣacaritra

Volume I: $\bar{A} d \bar{l}$ śvaracaritra. Translated into English by Helen M. Johnson.

Baroda 1931. Gaekwad's Oriental Series LI.

Trivedi, H.V.

1957 Catalogue of the Coins of the Nāga Kings of Padmāvatī. The Department of Archæology \& Museums, Madhya Pradesh, Gwalior.

Trivikrama

Madālasā-Campū, a Campū-kāvya attributed to Trivikrama-bhațta. Edit. by J.B. Modak and K.N. Sane. Poona 1882.

Atha Trivikrama-Bhatța-viracita Madālasācampū. Nirmalā-Hindī vyākhyā sahita, sampādaka evaṃ vyākhyākāra, Nirañjana Miśra. Satyam Publishing House, New Delhi 2005.

Trivikramabhatța

Damayantīkathā or Nalacampū, with the Commentary Vișamapadaprakāśa by Caṇdapāla. Edit. by N.B. Parvaṇikar, Durgāprasād and Śivadatta.

Tromp, Hylke Nirnaya Sagar Press, Bombay 1885 (2nd ed., 1903).

1991 Het heilige vuur in de heilige oorlog. Waarom vecht een soldaat? in: Bakker \& Gosman 1991, 225-33.

Tsuji, N.

1983 The Agnicayana Section of the Maitrāyaṇ̄-Saṃhitā with special reference to the Mānava Śrauta Sūtra. in: Frits Staal (ed.), Agni II, 135-160.

Tulpule, S.G.

1984 Mysticism in Medieval India. Wiesbaden.

Tulas̄i Dāsa

(RCM) Śrī Rāmacaritamānasa, or the Mānasa lake brimming over with the exploits of Śrī Rāma. With Hindi text and English translation. Gita Press, Gorakhpur 1968.

(tr. Hill) The Holy Lake of the Acts of Rāma. A translation of Tulasī Dās's

Rāmacaritamānasa by Douglas P. Hill. Oxford 1952.

(VP) Vinaya-Patrikā, [with the] Hari-Toșaṇī Ṭ̄kā by Viyogī Hari. Banaras 1977 (12th ed.).

(tr. Allchin) The petition to Rām. Hindi devotional hymns of the seventeenth century. A translation of Vinaya-patrikā with Introduction, Notes and Glossary by F.R. Allchin. London 1966.

Turner, R.L.

1966 Comparative Dictionary of the Indo-Aryan Languages. London.

Unbescheid, G.

1980 Kānphațā Untersuchungen zu Kult, Mythologie und Geschichte Śivaitischer

Tantriker in Nepal. Wiesbaden. 
Vākpatirāja

Vanderjagt, Arjo

Gaüdavaho. Edit. with an Introduction, Sanskrit Chāyā, English Translation, Notes, Appendices, and Glossary by N.G. Suru. Ahmedabad/Varanasi 1975.

Prakrit Text Society Series No. 18.

1991 Op weg naar Jeruzalem: pacifisme, gerechtvaardigde oorlog, kruistocht. in:

Varāhamihira

Bakker \& Gosman 1991, pp. 66-83.

Bṛhatsaṃitā of Varāhamihira. With English Translation, Exhaustive Notes and Literary Comments by Ramakrishna Bhat. Delhi 1981-82. 2 vols.

Vārāhaśrautasūtra

(VŚS) Vārāha Śrautasūtra belonging to the Maitrāyaṇiya recension of Kṛ̦nạa

Yajurveda. Crit. edit. by C.G. Kashikar. Pune 1988. Shree Balmukund

Sanskrit Mahavidyalaya Research Series No. 4.

Varenne, Jean

1960 La Mahā Nārāyaṇa Upaniṣad. Édition critique, avec une traduction française, une étude, des notes et, en annexe, la Prāṇāgnihotra Upaniṣad. Paris 1960.

Publications de l'Institut de Civilisation Indienne 11.

Vātsyāyana

The Kāmasūtram of Śrī Vātsyāyana Muni. With the Jayamañgalā Sanskrit

Comm. of Śrī Yaśodhara, edit. with Hindi Comm. by Devdutta Sastri.

Vaudeville, Ch.

Varanasi 1964.

1974 Kabīr, Vol. I. Oxford.

Vāyupurāṇa

(VāP) Mahāmuniśrīmad-Vyāsa-pran̄itam Vāyupurānam, etat pustakam

ānandāśramasthapaṇịtaị saṃśodhitam. [Poona] 1983. Ananda Ashrama

Sanskrit Series 49. [Reprint of the edition by H. N. Apte AD 1905]

Veer, Peter van der

1986 Gods on Earth. The management of religious meaning and identity in a North Indian pilgrimage centre. Utrecht. (diss.).

1987 'God must be liberated.' A Hindu Liberation Movement in Ayodhyā. in: Modern Asian Studies 21.2 (1987), 283-301.

Verardi, Giovanni

1983 The Kuṣāna Emperors as Cakravartins. Dynastic Art and Cults in India and Central Asia: History of a Theory, Clarifications and Refutations. in: East and West 33 (1983), 225-94.

Verma, Onkar Prasad

1973 A survey of Hemadpanti temples in Maharashtra. Nagpur.

Verma, T.P. \& Arvind Kumar Singh

1994 A Corpus of Lichchhavi Inscriptions of Nepal. New Dehli.

Verulkar, V.R.

1987 Kālidāsa Mahotsava. Vasanta Pạ̣cam̄̄ 1987. [Nagpur].

Vidarbha Sanshodan Mandal Annual

(VSMA) Nagpur.

Vipākasūtra

Viśākhadatta

See Abayadeva Sūri

Mudrārākșasa or The Signet Ring, a Sanskrit Drama in Seven Acts by

Viśākhadatta, crit. edit. with copious notes, translation, introduction and appendixes, indexes, etc. by K.H. Dhruva. Third edition (thoroughly revised and enlarged), Poona 1930.

Viṣnudharmottarapurāṇa

(VDhP) Viṣnudharmottarapurāṇa. [Edit. by] Kṣemarāja Śrīkrṣṇadāsa. Venkatesvara Press, Bombay V.S. 1969 [1912]. 
VDhP III Viṣnudharmottarapurāna. Third Khaṇda. Vol. I: Text, Critical Notes etc. Critically Edited with Introduction, Notes etc. by Priyabala Shah. Vol. II: Introduction, Appendixes, Indexes etc. A study on a Sanskrit Text of Ancient Indian Arts. Baroda 1994-98. 2 vols. Gaekwad's Oriental Series 130 \& 137.

Viṣṇupurāṇa

(ViP) The Viṣnupurānam, critically edited by M.M. Pathak. Pāda-Index by Peter Schreiner. Vadodara 1997-99. 2 vols.

Viyagappa, Ignatius

1980 G.W.F. Hegel's Concept of Indian Philosophy. Roma. Documenta Missionalia 14.

Vogel, J.Ph.

1930 La sculpture de Mathurā. Paris et Bruxelles. Ars Asiatica XV.

Wackernagel, Jacob

1896-1930 Altindische Grammatik, I (1896): Lautlehre. II,1 (1905): Einleitung zur Wortlehre. Nominalkomposition. III (1930): Nominalflexion - Zahlwort Pronomen, von Albert Debrunner und Jacob Wackernagel. Göttingen.

Ward, W.

1817 The Hindus, History, Literature and Religion. London. (repr. Delhi 1981).

Warder, A.K.

1989-92 Indian Kāvya Literature. Delhi. 6 vols.

Weippert, M.

1972 'Heiliger Krieg' in Israel und Assyrien. Kritische Anmerkungen zu Gerhard von Rads Konzept des 'Heilgen Krieges im alten Israel'. in: Zeitschrift für die alttestamentliche Wissenschaft 84 (1972), 460-493.

Wellsted, T.A.

1934 Notes on the Vakatakas of the Central Provinces and Berar, and their Country, 4th to 8th Century A.D. in: Journal and Proceedings of the Asiatic Society of Bengal, N.S. 29 (1933), 159-166a, Plates 4-12. [Printed at the Baptist Mission Press, published by the Asiatic Society of Bengal. Calcutta 1934].

White, David Gordon

1996 The Alchemical Body: Siddha Traditions in Medieval India. University of Chicago Press, Chicago/London.

Wilkins, Ch.

1785 The Bhâgvât-Geetâ, or Dialogues of Krêêshna and Ârjôôn; in eighteen lectures. With notes translated from the original Sanskrêêt, or ancient language of the Brâhmâns. London.

Williams, Joanna

1982 The Art of Gupta India. Empire and Province. Princeton.

1983 Vākāțaka Art and the Gupta Mainstream. in: Bardwell L. Smith 1983. pp. 215-33.

Willis, Michael

1997 Temples of Gopakșetra. A Regional History of Architecture and Sculpture in Central India CE 600-900. The British Museum, London.

2004 The Archaeology and Politics of Time. in: Bakker, Hans (ed.), The Vākātaka Heritage. Groningen. pp. 33-58.

2009 The Archaeology of Hindu Ritual. Temples and the Establishmnet of the Gods. Cambridge.

2014 The Dhanesar Kherā Buddha in the British Museum and the 'Politische Strukturen' of the Gupta Kingdom in India. in: South Asian Studies 30 (2014), 106-115.

Wilson, Frances

1975 The Love of Krishna. The Kṛsnakarnāmṛta of Līlāśuka Bilvamangala. Edited with an Introduction [and Translation]. Philadelphia. Haney Foundation Series 14 . 
Windisch, E.

1917-20 Geschichte der Sanskrit-Philologie und indischen Altertumskunde. Strassburg. 2 vols. Grundriss der Indo-Arischen Philologie und Indischen Altertumskunde I, 1 Bd. 1-2.

Winternitz, Moriz

1887 Einige Bemerkungen über das Bauopfer bei den Inder. in: Mittheilungen der Antropologischer Gesellschaft in Wien. XVII. Band. Wien. pp. 37-40.

1920 Geschichte der indischen Literatur, Band 3. Leipzig.

Wolpert, Stanley A.

1962 Tilak and Gokhale: Revolution and Reform in the Making of Modern India. Berkeley and Los Angeles.

Xuanzang

(Xiyuji) The Si-yu-ki. Buddhist Records of the Western World. Translated from the Chinese of Hiuen Tsiang (AD 629) by Samuel Beal. London 1884 (Indian edition, Delhi 1969).

Yazdani, G. (ed.)

1960 The Early History of the Deccan. Oxford. 2 vols. Yokochi, Yuko

1999 Mahisāsuramardin̄̄ Myth and Icon. Studies in the Skandapurāna II. in: Studies in the History of Indian Thought 11 (1999), 65-103.

1999a The Warrior Goddess in the Devīmāhātmya. in: M. Tanaka \& M. Tachikawa (eds.), Living with Śakti. Gender, Sexuality and Religion in South Asia. Osaka. Senri Ethnological Studies No. 50. pp. 71-113.

2004 The Relation between the Skandapurāna and the Āvantyakhaṇda. in: Bakker, Hans T. (ed.), Origin and Growth of the Puranic Text Corpus with Special Reference to the Skandapurāna. Delhi. Papers of the 12th World Sanskrit Conference Vol. 3.2. pp. 79-109.

2005 The Rise of the Warrior Goddess in Ancient India. A Study of the Myth Cycle of Kauśik̄̄-Vindhyavāsin̄̄ in the Skandapurāna. Thesis, Groningen.

Yugapurāṇa

A critically edited text of the Yugapurāna by D.R. Mankad. in: Journal of the United Provinces Historical Society XX (1947), 32-64.

Yuktidīpikā

(YD) The Yuktidīpikā, the most significant commentary on the Sāmkhyakārikā, critically edited by A. Wezler and S. Motegi. Stuttgart 1998. Alt- und neu-indische Studien 44.

Zaehner, R.C.

1960 Hindu and Muslim Mysticism. London. Jordan Lectures in Comparative Religion V.

Zehmke, Britta

1994 Die liegende Frau mit Kind in der indischen Steinplastik: eine typologiche Studie zur einzelplastischen Darstellung des Themas in der spätmittelalterlichen Kunst Zentral- und Ostindiens. 1, Text. Freie Universität Berlin, Berlin.

Zvelebil, K.V.

1974 Tamil Literature. Wiesbaden. A History of Indian Literature X.1.

Zwalf, W.

1996 A Catalogue of the Gandhāra Sculpture in the British Museum.Volume I:

Text; Volume II: Plates. London. 2 vols. 
Hans Teye Bakker - 9789004412071

Downloaded from Brill.comø4/26/2023 $04: 27: 16 \mathrm{AM}$

via free access 


\section{INDEX}

\section{The index has been made by Dory Heilijgers}

abhayamudrā, 109, 490, 522

Abhimanyu, 248

Abhinavagupta, 543

abhișeka, 100, 264, 535

Abhișekanātaka, 50

abhyāsayoga, 35-37

Abrahamic religions, 56, 61, 482, 486, 545

Abū 'Al̄̄ al-Sind̄̄, 6

Abu 'l-Fazl, 63, 64

Abu 'l-Kāsim al-Djunayd of Baghdad, 7

Abū Yazìd of Bisțām (Bāyazìd), 6

ācārya, 287, 305, 321, 330, 506, 508, 509,

$513,514,519,531,533,539,584,602,608$

Acharya, Diwakar, 539, 553, 558, 559

Ackermann, Hans Christoph, 437

Acyuta, 520, 589

Acyutanāyaka, 160

adharmiștha, 157, 481

adhikāra, 543

adhișthāna, 227, 259

adhyātman, 224

Ādikeśava, 467

Ādikola, 93, 109, see also Varāha

$\bar{A}$ diparvan (MBh), 489

Ādipurāna, 193

Ādipuruṣa, 589

Ādirāma, 94, 110

Aditi, 307

Āditya, 329

Addityagupta, 608

Ādityasena, 538, 539

Âdityavarman, 382, 383, 387, 388

$\dot{\alpha} \delta \circ \xi \grave{i} \alpha, 546$

Adriaensen, Rob, 185, 351, 609

advaita, 16, 18, 103

Advaita, 17, 94

Advani, Lal, 76

Afzal Khan, 478

Āgamas (Śaiva), 16, 293, 460, 463, 519

Agamic Saivism, 292, 464

Agasti, 529

Agastya, 90, 91, 94, 106, 337, 339

Agastya's hermitage, 91, 337, 340

Agastyasaṃhitā, 9, 16, 18, 61, 465, 466

Agathokles, 556

Aghora, 492, 521

Aghoraśiva, 296, 411

Agni, 264, 353, 354, 506, 507, 519

Agnicayana (altar), 447-449, 451, 452,
$455-458,460$

Agniśarman, 297

Agnitīrtha, 91, 99, 106

agrahāra, 328, 356, 539

Agrawal, Jagannath, 375

ahamkāra, 29, 30, 228

ăhatalakșaṇa, 129, 130

āhavanīya, 451

Ahicchatra, 419-422, 440, 580, 581

ahimssa, 458, 475, 476, 477, 578

Ahirs, 154

Aï Khanum, 555-557

aidūka, 406, 407, 413, 419-422, 424, 437, 438, 440

Ajanta (Caves), 119, 147, 260, 333

Ajanțā Cave Inscription of Varāhadeva, 127

ajina, 510

Ajitāgama, 411, 431

Ajmer, 9, 570

àjyapa, 353, 354

Akbar, 13, 570

Akbar Nāma, 63, 64

akhārā, 63, 64

Akșapāda (= Gautama?), 294

aksati, 476

Alampur, 580

àlaya (temple), 355, 530, 536

alchemy (rasāyana), 12

Alexander, 556

Alexandria on the Oxus, 556

Ali, Daud, 322, 323

All-India Kashiraj Trust, 179, 283

Allah, 8, 9, 11

Allahābād Posthumous Stone Pillar Inscription of Samudragupta, 244, 302, 328

Allchin, F.R., 408

Almore District, 399

$\alpha$-type-of-text, 183, 184

Altaï Mountains, 419

Altekar, A.S., 301, 311

Ālvārs, 17-20, 167, 168

āmalaka, 258, 260, 262, 263, 406, 575

àmalasāraka, 406, 421

Amara, 129, 130, 239, 240, 242, 243, 249

amarajakula, 239, 242

Amarakośa, 129, 146, 376, 408, 558

Amarāryakula (Amarārya family), 240-242, $245,256,260$

Amarāvatīi, 156, 172 
amātya, 124, 132, 322

Ambakunda, 91

Ambālā Tàlāb (pond), 91

Ambatīrtha, 91, 106

Ambikākhaṇda (A recension SP), 181, 185, 469

Ambikāpati, 91

Ambikānātha, 106

Āmbrakanagara, 236

American Institute of Indian Studies, 121

Amīr Khusraw, 90

Amīr ud-Dīn alias Amīr 'Alī, 68, 69

Ammaña, 89

Amoghavarșa I, 304

Āmrakārdava, 321

Amreli, 429

amrta, 490, 506, 519, 580

Aṃśuvarman (Mahāsāmanta), 538

Aṃśuvarman Samvat, 469, 538

anadudvrata, 545

Ānandaprabha, 255

Anandavardhana, 609

Ananta (Rudra), 285

Ananta (serpent king), 326, 361, 435

Anantadevī, 314

Anantamahādevīe 236

Anantaśayana, 319

anda, 437

Andhaka, 386, 603, 604

Andhau, 419, 439

Andhra Pradesh, 245, 252, 253, 453

Andhra(s), 89, 383, 388

Añguttara-Nikāya, 406

$\bar{A} \tilde{n}$ janeya (Hanumat), 91, 106

Anna of Austria, 363

anonymous Sanskrit literature, 175, 180

Anquetil-Duperron, A.H., 27

Antaka (Rudra), 285

antinomian praxis, 548, 549, 554

antyești, 410

Anugita, 229

anugraha, 541, 559, see also grace and prasāda

Anukramanikā, 604

anumantrita, 593, 594

anuparivāra, 427, 428

Anuśāsanaparvan (MBh), 489, 497

Aojjhā, 51

Aparājitā, 482

Aparārka, 408

$\bar{A}$ pastambadharmasūtra, 512

Āpastambaśrautasūtra, 448-450

aprakata, 71

apratigha (invincible), 308, 309

Apratigha Type of coins, 309
Apsaras(es), 497, 581

Aragrāma, 328

Arang, 236, 248

Ārang Copper-Plate of Bhīmasena II, 236

$\bar{A}$ rang Stone Inscription of Bhavadeva

Ranakesarin and Nannarāja, 240, 248, 250

aranya, 511

Aravalli, 429

Archaeological Survey of India (ASI), 80,

$115,156,305,337,373,391$

Ardhanārīśvara, 261

arhat, 424

Aristotle, 610

Arjuna (son of Prthā), 36, 40, 187, 248, 478, 481, 512, 522, 523, 525, 585-593, 595, 597, 599, 601

Arrianus, 479, 480

artha, 224, 227, 243

Arthapati Bhattāāaka, 142

Arthaśāstra, 55, 157, 452, 476, 479, 481

àryaka, 142

Asṣādhi, 554

ascetic (practice, etc.), 42, 64, 93, 107, 293,

$477,490,491,544,548,559,560,564,578$, $579,588,591$

ascetic orders (akhārās), 63, 64,

asceticism, 8, 39, 63, 336, 337, 490, 532, 546, $590,599,602$

ascetics, 11, 14, 61, 66, 68, 70, 93, 162, 288, 292, 293, 297, 321, 336, 399-401, 403, 410, $412,513,516,520,529,531-533,544-546$, 548-550, 553-555, 558-560, 577, 578, 581, $584,589,592,597,599,602$, see also warrior ascetics

Asher, Frederick M., 394

ashes (bhasman), 66, 110, 288, 294, 295, 407, $408,410,413,421,423,425,427,429,430$, 433-436, 438-440, 513, 515, 518, 532, 542, 544, 560, 592, 602

Asi River, 467

Asiatic Society of Bengal, 31

Asigarh, 253

Asighāt (Benares), 467

aśman, 511

$\overline{\mathrm{A}} \mathrm{sn} \overline{1}, 484$

aśoka (tree), 191

Aśoka, 144, 324, 428, 475-477, 479

āśrama (stages of life), 14, 531

āśrama (hermitage), 337, 534, 535

Assur, 59

Assyria, 5

aștamūrti, 190, 197, 291, 292

asthi-sañcayana, 410

astra, 593-595

Astraśiva, 296 
aśuddhādhvan (Impure Universe), 284, 285

Asuras, 159, 187, 307, 480, 489

Āśvalāyanagrhyasūtra, 509

Aśvamedha, 107, 150, 152, 154, 164, 447, 452,524

Aśvamedhatīrtha, 91

Aśvapati, 386

Aśvatthāman, 497

atah, 542

Ātānātiyasutta, 407

atha, 542

Atharvaveda, 47

Atharvavedapariśișta, 508, 559

atibhāvatī, 124, 134, 140

Atibhāvatī, 311, 316, 333, 352, 360, 361, 363, $371,372,413,414$

Aticandrā, 140

Atimārga, 285, 293

ātman, 227, 228, see also self

Atri, 295, 297, 529, 554

attahāsa (laughter), 544

Atțahāsa (sword), 531

atyāśrama, 524

Augustine, St, 56, 71

Aulikaras (Early), 308, 570, 571

Aulikaras (Later), 571, 588, 598, 599

Aupamanyava, 450

Aupaśatika gotra, 419

Aurangzeb, 66

Austro-Asiatic, 559

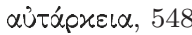

Avadh, 66, 68, 69, 72

avamāna, 546, 548, see also dishonour

Avantivarman, 303, 394, 397, 527, 601-605

$\bar{A}$ vantyakhanda, 469

avatāra (of Vișṇu), 18, 50, 64, 80, 90, 93, $175,346,35 \dot{3}, 542$

avatāra (of Śiva), 292, 293, 296, 494, 530, 553, 554, 559

twenty-eight, 559, 560

avimukta / Avimukta, 468, 471, 473

Avimuktajja (Skt. Avimuktārya), 539

Avimukta(kṣetra), 467, 470, 471, 472, 602

Avimuktamāhātmya, 468, 470

Avimukteśvara (Temple), 471-473, 533

avyakta, 228

axis mundi, 166, 335, 342

Ayachit, S.M., 90

Âycciyarkuravai, 168

āyatana, 473, 602, 606

ayodhya, 47

Ayodhyā, 5, 19, 20, 47-52, 55, 64-69, 71-74 $76,77,182,302,335-337,410,464,478$, 485,550

Ayodhyākhaṇda (Rām.), 182
Ayodhyāmāhātmyā, 52, 182

àyudhapurușa, 596

Aztec society, 153

Babri Masjid, 65, 66, 68-70, 72-74, 77, 337, 478, 485

Bābū Mairāl, 90

Bābūr, 65, 485

Babur's Mosque, see Babri Masjid

Bābūrām Press, 31

Bactria, 556

Baghelkhand, 146, 533

bagopouro, 417

Bahawalpur (Pakistan), 11, 426

Bahuriband, 347

Bajpai, K.D., 256

bak $\bar{a}^{2}, 7$

- bala (names ending in), 247

Bālacarita (of Bhāsa), 169

Baladeva/Balarāma, 171, 264, 556

Balajaya, 427, 428

Balanandin, 426, 428

Bāleśvara-bhatțākaraka Temple (Śrīpura), 290, 291, 293, 296

bali (tribute), 138, 410, 492

Bali (king), 159, 353, 369-371

Bali (island), 162, 411

Balogh, Dániel, 375, 376

Bamhan̄ Plates of Pāndava King Bharatabala, Year 2, 237, 239, 242

ban-practice, 59

Bāṇa, 303, 405, 406, 421, 527, 528, 531, 535, 536, 603, 605, 607

Banaras Hindu University, 377

Bandhuvarman, 308

Banerji, R.D., 395

Baptist Missionary Society in Bengal, 70

Barbero, A., 346, 349

Barhut, 253

Barhut Inscriptions, 406

Barkhuis, Roelf, 465

Barlow (Captain), 69

Baroda, 90, 297

Basarh (Vaiśālī), 137, 140

Basarh sealing, 140

Bastar District, 173, 347

Baudhāyanagṛhyapariśiștasūtras, 497, 502

Baudhāyanagrhhyasūtra, 510

Baudhāyanaśrautasūtra, 448-450

Bauma-Kara kings, 402

Bayana hoard (coins), 308

Bāyazīd, see Abū Yazīd of Bisṭām

Bedekar, V.M., 179

begging bowl, 578, 580, 589, 594, 596, 597

Benares, 69, 74, 465, 467, 469, 473, 484, 534, 
602, 604, 605, see also Vārānas̄̄ and Kāśs̄

Bengal, 17, 31, 169, 453

Benisagar, 539

Beṇn̄ā River, 324, 332, see also Vainyā and

Waiganga River

Bennātatasthāna, 325, 332

Berach River, 567

Berlin, 24, 26, 34, 44

Besnagar, 302, 305, 320, 321, see also Vidiśā

Bhabua, 391

Bhaddā (queen), 408

Bhadrabāhu, 51

Bhadrakālī, 524

bhadrapitha, 406, 407, 419, 421, 437

Bhadravisnu, 399

Bhadreśvara, 248, 602, 605

Bhaga, 188, 189, 195, 196

Bhagalpur, 75

Bhagavadgītā, 9, 31, 33-35, 37, 38, 43-45, $61,62,477,478$

bhagavat (lord), 414, 431, 529

Bhagavat (Viṣnu), 155, 320, 326, 330, 333, $340,341,344,352,376$

Bhāgavata (cult), 80, 321, 326, 328, 330, 353

Bhāgavata (devotees), 319, 325, 326, 329, 331,438

Bhāgavatapurāṇa, 17, 18, 169, 284

Bhagavatism, see Bhāgavata cult

bhāginey $\bar{\imath}, 115,132,140,311,358,359,361$ 363

Bhāgraharāja, 236

Bhairava, 93, 292, 420, 521

Bhairava Darwāzā, 91

Bhairava (Mantrapitha) Tantra, 284, 292, 296

Bhairava tradition, 292, 293, 532

Bhairavācārya (teacher), 531

bhajan, 15

Bhaktas, 15-21, 165, 170, 407, see also Śivabhaktas

bhakti, 8, 9, 15-18, 20, 164, see also Rāma, Krsna and Vaisnava bhakti

bhakti movement, 15, 17, 19, 162, 165, 168

bhaktirasa, 19

bhaktiyoga, 36, 39

Bhāndāgāāa, 290, 291

Bhandara District, 326, 418

Bhandarkar, D.R., 494, 569, 570-574, 576

Bhandarkar, Ramkrishna Gopal, 375-377

Bhānūdayin, 398-400

Bhānugupta, 244

Bhārabhūti, 554

Bhāradvājagṛhyasūtra, 510

bhārarakșakas, 261, 267

Bharata, 248, 410, 411, 416, 417, 478
Bharatabala, 238-240, 242, 243, 249

Bharatanātha, 81

Bhāratavarșa, 519

Bhāravi, 588, 589, 597

Bhargava, 535, 536

Bharhut, 328

Bharukaccha, 563

Bhāsa, 50, 169, 410, 416, 417

Bhāsarvajña, 514, 515

Bhāskaravarman, 255

bhasman, see ashes

Bhasman (Rudra), 285

Bhatsu, 603

Bhaț̣arāī, Kṛ̣ṇaprasāda, 185

Bhattasanghasena, 330

bhāva (state of modification), 224, 225, 227, 228,230

bhāva (emotional state), 21, 334

Bhava (Rudra-Śiva), 190, 197, 285, 497, 524

Bhavadattavarman, 142, 143, 147

Bhavadeva, 240, 248, 250

Bhavanāga, 324

Bhavān̄̄, 197

Bhavattavarman, 142

Bhāya (kumāra), 415

Bhikșātana, 520

Bhikṣātanamūrtis, 578

bhikșu, 426, 439

Bhillama, 89, 159

Bhīma, 160

Bhīma (Rudra), 285

Bhīma (Śiva), 190

Bhīmasena, 236

Bhīmasoma, 290, 291, 293, 296, 297

Bhīsma, 230, 293

Bhita, 490-492

Bhitargaon, 581

Bhitarī, 376-378, 413

Bhitarī Stone Pillar Inscription of Skandagupta, 146, 315, 316, 333, 373, 374, 377-379, 414

Bhogarāma Temple, 93, 94, 110, 163

bhogasthala, 52

Bhogavarman (Maukhari), 530, 538, 608

Bhogavarman (son of Śūrasena), 538

Bhojadeva, 532

Bhonsle / Bhonsalas, 91, 255, 356, 365

Bhrgu, 534, 536

Bhūdevī, 330

bhukti, 18, 466

Bhulunda, 326

Bhūmarā, 575

bhūmikā, 406, 421

Bhūtas, 516

bhūtakrt, 231 
bhūtamātra, 224

bhūtarāja, 156

Bhūteśvara, 580

bhuvana, 284, 406

bhuvanaguru, 531

Biardeau, Madeleine, 179

Bibliothèque Nationale in Paris, 32

Bihar, 75, 391, 412, 429, 539, 595

Bilaspur District, 253, 256

Bilaspur Museum, 261

Bilsad Stone Pillar Inscription of Kumāragupta, Year 96, 308

biruda, 244, 250, 308, 315

Bisschop, Peter, 248, 532, 537, 553, 559, 564, $576,577,610$

BJP, see Indian People's Party

Black Yajurveda, 449, 450, 510

Bloch, Theodor, 391, 394, 412

Bodewitz, H.W., 477

Bodhisattva, 13, 61

Bodleian Library, 169, 194

Bogra District, 453

Boṃī Huḍkī, 329, 333

Bommagaṇți Appayārya, 129

Bonazzoli, Giorgio, 179, 180, 181

Bonaventura, 544

Bonda Plates of Mahāśivagupta, Year 22, 254

Bonn, 33

book (attribute), 519, 521, 522

Bopp, Franz, 32, 34

Bosma, Natasja, 247, 249, 254, 296, 610

Boța, 239

Brahmā, 38, 41, 91, 106, 160, 190-192, 195-198, 265, 401, 460, 464-466, 489, 498, $549,582,588,589,594,598$

Brahmā's Head (brahmaśiras), 523, 589, 593 , 594-596, 598, 599

brahmacārin, 490, 491, 506, 509, 511, 527

brahmacarya, 506

brahman, 30, 36-39, 41-44, 188, 223, 295, $506,534,549,585,589,594$

five (pañcabrahman), 492, 493, 513

brahmán priest, 187, 188, 190, 508

Brahman, see brahman and brahmin

Brāhmaṇa(s), 187, 192, 193, 195, 446, 562

Brahmāndapurāna, 51

brahmanical (tradition, view, etc.), 151, 152, $155,158,417,447,462,417,477,498,544$

Brahmanism, 56, 154

Brahmapurāna, 186, 192, 193, 196-199, 223, 408

brahmasattra, 607

brahmaśiras, see Brahmā's Head

brahmasūtra, 406
Brahmasvāmin (Rudra), 285, 287

brahmin, 33, 38, 39, 42, 55, 62, 63, 65, 105, 151, 153, 157-162, 190, 291, 294, 295, 328, 332, 336, 337, 354, 363, 405, 409, 411, $447,471,496,505,511-513,542,543,546$, $558,560,563,564,584,589,604,605,607$ brahmodya, 546, 554

Braj, 18, 20, 71, 170, 464, 550, 551

Bremmer, Jan, 541, 551

Bṛhadārya, 529

Bṛhadbrahmasaṃhitā, 52

Bṛhaspati, 106, 110, 188, 231

Bṛhaspati Cycle, 85

Bṛhatphalāyana gotra, 418

Brhatsamhitā, 460, 482

brick consecration, $73,74,76$

bricks, 449, 451, 452, 455-457

Brinkhaus, Horst, 180

Britain, 68

British Museum (London), 308, 309, 313, 331, 425, 432, 434, 609

British Rule, 68, 69, 445, 478

brush, 578-580

Bryant, Kenneth, 168

Buchanan, Francis, 391, 392

Buckee, Fiona, 393, 394, 402

Buddha, 49, 255, 261, 424, 436, 437, 553, 562,602

buddhi, 29, 30, 224-230

buddhir uttamā, 226

Buddhist, 4, 13, 79, 321, 330, 333, 406-408, 412, 417-419, 422, 424-426, 430, 435, 437-440, 477, 521, 553, 583, 602

Buddhism, 24, 61, 321, 429, 437, 483, 544

Bühnemann, Gudrun, 90

Buitenen, J.A.B. van, 223, 224, 228-230

bull, 544, 545, see also Vṛșa

bulva / bulba, 506, 507

Bundelkhand, 302

Būrhīkhar, 238, 240

burial mounds, 412, 413, 419, 425, 439, 451, see also edūka

burial chamber, 438

Burkert, W., 57

Cāhamānas, 482-484

Caitanya, 18, 169

caitya, 409

caityagrha, 425

Cākorḍā, 91

cakra (Viṣnu's discus), 91, 107, 189, 320, 326, $327,343,361$, see also Sudarśana

Cakradhara, 163

Cakrapālita, 144 
Cakrapāni, 153, 326

Cakratīrtha (Ramtek), 91, 107, 145

cakravartin, 51, 85

Caland, W., 409, 449, 450

Calcutta, 31, 392, 595

Cālukya(s), 80, 81, 142, 259, 260

Cambodia, 411, 563

campū, 86

Cāmuṇda (adhipati), 87, 88

Cāmuñāā, 130, 137

Cāmundasoma, 294

Cañālasvāmin ( $\bar{a} c \bar{a} r y a), 330$

Canda, 558

candāala, 473

candra, 131, 307, 310, 327, 362

Candradeva, 484

Candrakșamaṇa, 321

Candragupta (brother of Tivaradeva), 247, 253

Candragupta I, 139

Candragupta II, 114, 115, 126, 131, 137-140, 154, 301-311, 319-323, 326, 330, 333, 352, 358-363, 414, 495

Candragupta Maurya, 144, 303, 479

Candrahāsa, 93, 109, 338

candraka, 406

Candraprabha, 321

candraśālā, 574, 575

Candrāvatīi, 138

Cangadeva (astronomer), 85

cannibalism, 444

Cāṇūra, 171

carana (school), 328

caste, $3,5,12,14,16,19,21,24,38,40,542$

Catholic Church / Catholicism, 60, 543

cattle, 245, 443, 448, 544, 545

caturmukha, 489

caturmukhalinga, 393, 400-402, 490, 492, 493, 499

caturmūrti, 490

Caturvargacintāmaṇi, 159

Cecil, Elizabeth, 562

Celukșamana, 321

cemetery, 411, 430, 437, 455

Central Asia, 556

Chakravarty, K.K., 259, 261

Chambal River, 302

Champaran District, West, 412

Chandawar, 484

Chandra Shum Shere collection, 169

charisma, 30, 162, 165

Charles II of Austria, 363

Chartres, 52

chatar $\bar{\imath}, 405,431$

Chatracandeśvara, 531 chattri, 437

chāyā, 418

chāyāstambha / chāyāskambha, 417, 418

Chézy, Léonard de, 32, 34

Chhabra, B.Ch., 375

Chhattisgarh, 235, 237, 347, 348, 577

Chitor (= Chi-ki-to), 562

Chittorgarh, 570-572, 598

Chittorgarh District (Rajasthan), 567

Christ, 8, 9, 547

Christian, 8, 9, 11, 60, 548, 550, 551

Christianity, 57, 546, 550, 551

Čishtī order / Čishtīs, 9, 10

citācaitya (funerary monument), 421

citi, 410, 425, 429, 439, 440, 449, 451

civitas dei, 61, 71

club (attribute), 289, 342, 343, 523, 529, 554, $555,557-561,584,593$, see also gad $\bar{a}$, laguda, lakula

coins, 63, 140, 155, 239, 242-245, 260, 302, $305,306,308,309,315,316,375,397$, $417,428,430,556,557,569-570,609$

coins, types of,

Apratigha, 309

Archer, 309, 375

Hercules-type, 557

King-and-Lady/Lakșmī, 316, 375

Lion-slayer, 305

Colas / Colas, 89, 413, 520, 521

Colas, Gérard, 514, 518

Colebrooke, Henry, 28-30, 33, 35, 36, 38

Colpe, Carsten, 57, 58

Combray (France), 52, 53

communal unrest, 55, 76, 475, 478

communalism, 71

community, 60-64, 70-72, 77, 165, 551

composition-in-performance, 177, 178

composition-in-transmission, 177, 178, 184, 199,231

Confucius, 28

Congress Party, 73, 74, 76, 77

construction sacrifice, 445, 452, 453, 455, 458, 459, 462

Copper Plate Hoard from Bagh, 325, 328

Corintheans, 547

Council of Trente, 543

Council, Fourth Lateran, 543

creator (srastr), 228

cremation, 405, 407-410, 412, 413, 425, 429-431

cremation ground, 295, 430, 471-473, 531, $542,544,549,560,602$, see also śmaśāna; (eight / nine), 431

Creuzer, Friedrich G., 24

critical edition, 169, 175, 176, 178, 179, 
181-183, 185, 187, 194, 196, 198, 223, 225, 283, 285, 290

Crooke, William, 444

crusade, 56, 58-60, 71, 72

Cunningham, Alexander, 313

Curdi, 461, 462

Cyavana, 534, 536

Cynics, 546, 548, 554, 558

Cyprus, 547

Dadhīca, 534-536

Dahala, 150

daityas, 197, 369, 371, 512

Dakșa('s sacrifice), 189, 420, 524, 525, 534, 576-579, 584, 587

dakșina/a, $516-518$, see also right side

dakșinā (fee), 163, 415

Dakṣiṇa Kosala, 48, 65, 147, 235-245, 247, 250, 251, 253, 255, 289, 296, 297, 419, $532,539,601$

dakșināmūrti (concept), 516-520

Dakṣin̄āmūrti, 420, 496, 505, 506, 516-522, $525,526,560,573,576,580,587,596$, see also southern mürti

Damana, 426

Dāmodarasena, 141, 314, 332

dāna, 163

Dānarāśi, 532

Dānavas, 593, 595

danda, 558, 559

Daṇda (king), 337

Daṇdakāranya, 337

Dandapāni, 558

Dani, Ahmad Hasan, 119

Daniell, Thomas, 391-393

darbha grass, 510

Darpaśāta, 606

Darya-i Pandj River, 555

Dāsa, 570

Daśapura (modern Mandasor), 307, 308, 570, 571,598

Dasarā, 482

Daśaratha, 48, 64, 93, 109, 173, 335, 411

Daśārṇa, 302

Dasnāmī (Śaiva order), 12, 13, 18

dāsya-rasa, 21

Dattabhața, 308

Daub, 30

dauhitra $/ \bar{\imath}, 244,324,537,538$

Daulatabad, 150

Day of Resurrection, 7, 8, 63

dāyāda, 146

De Marco, Giuseppe, 410, 412, 424, 425, 431, 436,437
Deccan, 79, 81, 139, 149, 150, 259, 301, 304, 413

Degroot, Véronique, 567, 576

Dehra Dun District, 447

deification, 52, 161, 164

Delhi, 4, 9, 77, 90, 492, 495

Delhi Sultanate, 323

Deo, S.B., 170

Deogarh, 356, 367, 368, 574, 581, 588, 589

Deopātana Inscription, Samvat 39, 538

Deotek, 324

Deotek Stone Inscription of Rudrasena, 118, 323,325

Der Zauberberg, 548

deśadaivata, 481

Deur Temple, 577

Deuteronomium, 59

Deva, Krishna, 236, 251, 259

deva, 126, 152, 310

Devadāruvana, 548, 578-583, 586, 587, 598, 599

Devadeva (Śiva), 192, 197

Devadeva (Viṣnu), 361

Devāditya, 86

Devagiri (modern Daulatabad), 150, 160

Devagupta, see Candragupta II

Devak̄̄, 316

devakula, 395, 399, 400, 410, 415-417, 440, 539

devakulapati, 400

devakulasthāna, 332, 424, 435, 495, 496

devanāgarī, 33

Devānāminpriya Priyadarśin (Aśoka), 475, 476

devanikāya (Temple Council), 398-400

devaputra, 417

Devarakșita (brahmin), 250

Devarānī Temple (Tālā), 256-260, 262, 264, 272,281

Devas, 165, 307, 606

Devasena, 144, 146, 147, 372

Devasomā, 293

Devī (the Goddess), 196, 197, 264

Devīcandragupta, 303, 305, 312

devodyāna, 471

Dey, Nundo Lal, 337

Dhām (river), 141, 170

Dhamatari Plates of Sudevarāja, Year 3, 249

Dhana(deva) (king), 419

Dhanustīrtha (Ramtek), 91, 107

dhā $\bar{a}, 388$

Dhāraṇa gotra, 312, 328, 414, 438

Dhārin̄ì , 311, 312

dharma, 40, 64, 65, 107, 108, 126, 150, 152, $153,159,161,162,243,310,322,336,350$, $363,364,409,480,481,483,524$ 
Dharma, 585, 586, 602

dharmamahārāja, 153, 333

Dharmanibandha, 182

Dharmaśāstra, 152, 477

dharmaśilana, 475

dharmasthāna, 157, 324, 326, 328, 332

Dharmasūtra, 152

dharmavijaya/yin, 153, 476

Dharmeśvara, 93, 108

dharmistha, 476

Dhavalikar, M.K., 460

Dhenkanal District, 402

Dhenuka, 171

Dhenukāsuravadha, 171

dhikr, 10, 11

dhoti, 585

Dhṛtarāṣtra, 406, 407

Dhruva, K.H., 303

Dhruvadevī / Dhruvasvāmin̄̄, 303, 304, 307

Dhruveśa (Rudra), 287

Dhūmrākșa, 93, 109, 338, 339, 350

Dhūmreśvara, 339

Dhūmreśvara Temple, 338

dhvajastambha, 568

Dhvanyāloka, 609

Digambara, 321

dikpāla, 81

dīkșā, 513, 528

dīnāra, 398

Dindimunda, 554

Diogenes, 546

Dīptāgama, 410, 411

Dīrghaśiva, 296

disciples of Lāgudi, see four disciples

dishonour (avamāna), 544-546, 548

Diti, 307, 353, 371

Divākarasena, 141, 314, 329

divyadeha (divine body), 12, 13

Divyāvadāna, 407, 428

Dja cfar al-Sādik, 6

domestic sacrifice, 155, 446, 507

Donaldson, Thomas E., 256

Dongar Maudā, 327

Dowson, John, 484

Dravida, 405, 408

Dravidian, 175, 259, 260, 408

Drona, 187, 293

Dronabhatțārakā, 239

Droṇāka, 249

Dronaparvan, 187, 190, 199, 496, 497

drstam, 324

dualism, 30, see also dvaita

Duboc, Ed., 25

duḥkhānta, 525, 542, 550, 583, 593

Dumont, Louis, 4, 5
Dundas, Paul, 321

Dundubhi (Rudra), 285

Durgā, 482

Durjanpura, 305, 321

Durkheim, E., 58

Dutthagāman̄̄, 428

Dvaidha Sūtra, 450

Dvāparayuga, 336, 554

Dvārakā, 108

dvārapāla, 91, 320

Ecclesiastes, 505

Edgerton, Franklin, 228, 408, 443, 444

edicts (Aśoka), 476

edūka (funeral monument), 332, 407-410, 420, 424, 429, 438, 440

Ehavala Cāntamūla, 325

Ekādaś̄ day, 108, 330

ekamukhalinga, 320, 401, 402

ekaveni, 306

elements (five), see mahābhūta

Elephanta, 246, 561

Elliot, H.M., 484

elūkā, 407, 408, see also edūka

Emeneau, M.B., 408

Emesa, 547

England, 56

ens realissimum, 551

Eran, 244, 305

Erdheim, Mario, 153, 162

Eschmann, A., 155

ethnocentricity, 551

Eucharist, 543

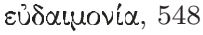

Eumenides, 520

European Association of South Asian

Archaeologists, 373

evil, 59, 60, 77

exclusive, 59, 60, 77

Faizabad, 73

fakìr, 11, 62

fan $\bar{a}^{\text {' }}$ (passing away), 6, 7, 10

festivals, 330, 478, 482, 606, 607

fire-altar, 447-455, 462

Fleet, J.F., 375, 377, 381, 382, 383

footprint ( pada / pāda), 341-343, 346, 347

formulaic style (formularity), 176-178

Fort William, 31

four disciples of Lāgudi, the, 559-564, 584

France, 52

Frank, Othmar, 32

Frauwallner, Erich, 223, 227-231

fundamentalism, 71-73, 76, 486 
funeral pyre, 405, 406

funerary monuments, 378, 405, 408, 411, 413, 417, 419, 421, 424, 425, 429, 431, 435-437, 440, see also elūkā, eḍuka, aiḍūka

Furies, 520

Fussman, Gérard, 416, 417

$\operatorname{gad} \bar{a}(\mathrm{club}), 342$

Gaeffke, Peter, 26

Gāhadavāla(s), 467, 469, 483, 484

Gahana/eśa (Rudra), 285, 286, 290-293, 532

Gai, G.S., 571

Gaikwars, 90

Gail, A., 180

Gajendravadana, 93

Gambhīra (brahmin), 536

gana(s), 261, 262, 265, 273-276, 420, 587

Gaṇakārikā, 513-515, 518

Gaṇapatināga / Gaṇapatīndra, 302

Gandak̄̄ (river), 605

gandha, 225

Gandhāra, 412, 424, 429, 436, 440

Gandharvas, 265, 407, 497, 516, 593

Gandharveśvara Temple (Sirpur), 248, 255, 293, 532

Gandhi, M.K., see Mahātma Gandhi

Gandhi, Rajiv, 73, 74, 76

Gaṇendra, see Ganapatināga

Ganeśa, 108, 261, 262, 272, 320, 330, 333, 464

Ganeśa Nātu, 194, 198

Gañgā, 243, 264, 463, 465, 474, 580, 607, see also Ganges

Gañgā-Yamunā doab, 323

Gañgā Valley, 533

Gañgādvāra, 524, 602

Gañgāsrotas, 91

Gangdhar Stone Inscription of Viśvavarman, 132

Ganges, 48, 49, 79, 108, 294, 302, 306, 408, 467, 603, 606, see also Gañā

Gangetic Plain, 149, 347, 483

Gaolis, 154

garbhagrha, 83, 88, 261, 329, 515, 521, 522

Garde, M.B., 430, 560

Gārgya, 295, 527-529, 562

Garh-Dhanora, 347, 348

Garuda, 315

Garuḍa standard, 309, 315

Garudapurāṇa, 181

Gaudas, 388, 601, 605, 606

Gauḍvaho / Gaüdavaha, 482, 531

Gaurī, 261, 463

Gautama gotra, 160
Gautamadharmasūtra, 510

Gautameśvara, 106

Gautamīputra Sātakarṇi, 138

gavākṣa, 568

Gayā, 51

Gāyakhur̄̄, 91

Geer, Alexandra Anna Enrica van der, 411

Geertz, Clifford, 162

Geneva Convention, 479

Gentz, Friedrich von, 35

Gēsū-darāz, 10

Ghanțeśvara, 91, 106

Ghaṭo (gold coin, St. Petersburg collection), 140,315

Ghatotkaca Cave Inscription of Varāhadeva, $119,120,127,130$

Ghatotkaca(gupta) (son of Candragupta II), 114-116, 126, 139-141, 309-311, 314-316, 358-364, 372, 413

Ghatotkacagupta (son of Śrīgupta), 139

Ghazni, 63

Ghosh, Ajit, 315, 411, 421

Ghoṣụ̣̣̄̂̄ Well Stone Inscription, 570

Ghotapadrakagrāma, 250

Girijā, 463

Girinagara (Junagarh), 144, 145

Girnār, 388

Gìtā, 34-36, 40, see further Bhagavadgìtā

Giuliano, Laura, 335

Goa, 461

Gobhilagṛhyasūtra, 492, 509

Gogra, 48

Gokhale, S., 120

Gokul / Gokula, 20, 173, 453, 459

Golakyānti, 321

golden man, 448-451

Gomibhața (general), 397-399, 402

Gomundāa, 137

Goncourt brothers, 551

Gonda, Jan, 508, 513

Gonḍārya, 158

Gonds, 154, 158

Goodall, Dominic, 285

Gopāla (Krșna), 93, 109

Gopālarājavaṃśāvalī, 530

Goparāja, 244

Gopati (Rudra), 285, 286

gopis, 21, 93, 109

Gopratāra, 50

Gorakhnāth, 12, 13

Gorakhnāthīs, 12, 431

Gorakhpur, 12

Gosaladevī, 467

gotra, 85, 86, 160, 295, 312, 328, 354, 414, $418,419,438,542$ 
Govardhan, 20

Govinda (Krșna), 307

Govinda IV, 304

Govindacandra, 467, 469

Govindagupta, 307-311, 314

Govinda(svāmī $), 20$

Govindavarman, 251

govrata, 545

grace, 10, 14, 17, 18, 108, 153, 154, 160, 161, 165, 285, 291, 293, 295, 322, 326, 463-465, 516-519, 524, 526, 542-544, 549, 550, 559, 583, 584, 586, 593, 599, see also anugraha, parigraha, prasāda

Grahavarman, 527, 536, 605

graiveyaka, 263

grāma, 239, 250, 256, 290, 328, 376, 377

Granoff, Phyllis, 425, 459, 505, 516

Grant of Bhulunda, Year 47, 326

granthi, 284, 287, 291

Grdhrakūteśvara, 537

Greaves, Laxshmi, 421, 581

Greece, 24-26, 28, 42, 57, 58, 520

Greek, 176, 418, 443, 479, 546-548, 554, 555, 557,558

Grenet, Frantz, 416, 417

Gṛhyasūtras, 446, 508, 509, 510

Griffiths, Arlo, 411

Groningen, 185, 284, 351, 374, 391, 601

Gudimallam, 493

Guheśvara, 532

Guhyasūtra, 559

Gujarat, 62, 86, 119, 388, 419, 429, 482, 528, $553,557,561,563$

guna (quality), 40, 229, 406

guna (modification), 225, 228, 229

Guṇaratna, 529

Guntur District, 171

Gupta(s), 50, 51, 80, 114-116, 127, 132, $137-141,149,150,156,158,242,244,259$, $262,301-312,320,322,323,329,332,333$, $352,375,377,378,414,421,438,471,533$, $534,570,573,581,601-603,608,609$, passim

Gupta(s), Later, 537-539, 608

Gupta Empire, 305, 306, 315, 402, 553, 571, 604

Gupta Era (G.E.), 144, 235, 236, 325, 394

Gupta-Vākāṭaka relationship, 115, 145-147, 312, 314-318, 357-364

Gupta, A.S., 179

Gupta, Chandrashekhar, 173

Gupta, P.L., 315

Guptarāma, 94, 110

Gurjaras, 89, 160

guru, 10, 230, 287, 478, 512, 514, 515, 517,
$518,521,561,562,564,584,602$, passim guruparikti, 292

gurvāyatana, 287, 494

Habsburg, 363

Hacker, Paul, 60, 175, 179, 180, 182

Hadīth kudsī, 8

Haihaya, 88

Hakusiri (kumāra), 415

halanta forms, 119

Halbfass, Wilhelm, 23

Hamilton, Alexander, 32

Hamlapuri, 79, 150, 151, 155, 330

Hamsatīrtha (Ramtek), 91, 107

Hanumāngarhh̄̄, 66-69

Hanumat, 21, 90, 91, 93, 106, 109, 111, 144, 164,339

Hanumat Temple (Ramtek), 93

Hara (Śiva), 191, 463, 464, 524

Hara, Minoru, 283, 284, 553

Haraha Inscription of the Reign of Ísanavarman [VS] 611, 252, 253, 381, 383, $386-389,397$

Harapāladeva, 90

Hardy, Adam, 394

Hardy, Friedhelm, 16-18, 167, 168, 194

Hari (Viṣnu), 105-107, 164, 165, 254, 464, 588

Haribhadra, 189, 529

Harirāja (Śūra family), 236

Hariścandra, 473

Harisena, 146, 147, 244, 333

Harivamśa, 167, 168, 604

Harivarman, 382, 383, 386-388, 533

Harle, James, 368, 520

Harșa(vardhana), 303, 389, 394, 405, 469, $531,534-536,538,553,605-608$

Harșa Era, 392-394

Harșa kā Ṭ̂lā, 528, 531

Harșacarita, 139, 302, 303, 405, 406, 527, $528,531,535,605$

Harsagupta, 251, 253, 532

Härtel, H., 556

Hasan Nizāmīe 484

Hastings, Warren, 31

Hathayoga, 11

Hāthī-bādā, 570

Head of Brahmā, see Brahmā's Head

Heesterman, J.C., 477

Hegel, G.W.F., 3, 4, 23-33, 35, 36, 38-45

Heine, Heinrich, 32, 44

Hemādpanti style, 92

Hemādri, 159, 160

Heracles, 554-558, 564 
Herder, Johann Gottfried, 25, 55

hermitage, 91, 157, 337, 340, 409, 481, 512, 579, see also àśrama

hero-stones, 413, 417

Hiḍimbā Ṭekḍ̄ì 331, 332, 422, 432, 455, 456, 495, 496

Hilair, St, 53

Himachal Pradesh, 76

Himālaya, 340, 601

Himavat, 191, 192, 517, 590

hims $\bar{a}, 477$

Hind, 62, 484

Hindū Rāṣtra, 72

Hinduism (concept), 70

Hindustan, 478

Hingalaj, 12

Hiralal, Rai Bahadur, 236

Hiranyakeśigṛhyasūtra, 510, 511

Hiranyakeśiśrautasūtra, 449

Hiraṇyānadīvāsaka, 325

Hisse-Borala, 144, 145, 372

Hisse-Borala Inscription of Devasena, 119, 144,372

Hiraṇyakaśipu, 90, 106, 254, 346, 353

Hitavada, 75

Hitopadeśa, 32

Hoekstra, A., 176

Hoffmeister, Johannes, 30

Hofstra, Jan, 546

holy place(s), 5, 19, 20, 463, 464, 473, 481, 484, 539, see also tīrtha

holy war, 55-60, 62, 71, 77, 78, 481, 483, 485,

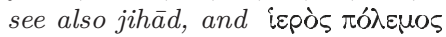

homa, 446, 510, 511

Homer, 176

Homo Hierarchicus, 21

Hopkins, E.W., 496

horse sacrifice, 311,447 , see also Aśvamedha Horstmann, Monika, 463

house, (installation of), 444, 446-447, 460, see also vāstu and Vāstupratișthā

householder, 4, 14, 513, 584

Hṛdaya (Pramāṇa text), 286

hudum, 545

Hulin, Michel, 23, 29, 30

HUM, 197

human sacrifice, 444-447, 450-452, 455, 458, see also Purusamedha

human skulls, 287, 288, 454, 455

Humboldt, Wilhelm von, 26, 31, 34-36, 39, 40

Hūṇas, 375, 414, 481, 553, 598, 601

al-Husayn b. Mansūr al-Hallādj, 7

Hussein, Saddam, 56

Huvișka, 415, 416

Hydarabad District, 453
Hymn of Creation (Rgveda X.129), 443

I Ching, 28

Ibn Asīr, 482

Ibn Batṭūta, 48

iconographic(al), 263, 333, 499, 506, 554, 555, 581, passim

iconography, 170, 320, 334, 342, 343, 346 , 368-371, 490, 519-522, 558, 569, 573, 576, 583, 609, passim

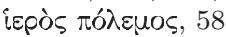

Ikkhāgabhūmi, 51

Ikṣvāku(s), 47, 51, 325, 337, 411, 418

Illiers(-Combray), 52, 53

imām, 69, 75

imitatio dei, 544, 545, 548, 550

India Office (London), 169, 484

Indian Museum (Calcutta), 392, 595

Indian philosophy (schools), 24, 27-30, 38, 41, 44, 60, 443, 444, 447, 511

Indian People's Party (BJP), 73, 74, 76

Indo-European, 32

Indo-Greek, 556

indologists, 152, 177, 186, 445, 447, 546, 609

Indology, 31, 44, 381

Indonesia, 445

Indore Plates of Pravarasena II, Year 23, 146, $329,364,375$

Indra, 20, 60, 109, 110, 126, 141, 151, 187-189, 192, 195, 264, 307, 308, 310, 316, $354,360,387,489,506,585,586,589$, $590,597,606$

Indrabala(rāja) (sāmanta), 240, 247-250

Indrabhatțārikā, 238, 239

Indragarh Stone Inscription of VS 767, 532

Indrakīla (mountain), 590

Indrapura, 250

indriya (senses), 224-230

Indus River, 437

Ingalls, Daniel, 546, 553-555, 558

initiation, 291-294, 296, 467, 505, 506, 512-516, 518, 527, 528, 543, 544, 560, 576, 586, see also dikssā

Inscription of Ajanțā Cave XVII, 127

Institute of Indian Studies, Groningen University, 284, 351

Institute of Learning and Research, Ahmedabad, 283, 284

Iran, 417

Isaacson, Harunaga, 185, 194, 351, 352, 514, 609

İsāla(tīrtha), 92

Ísāna, 190, 493

İsāna (Pāśupata teacher), 529 
Íśānadeva, 240, 249, 250

İ́ānavarman, 252, 253, 381, 383, 388, 389, $527,533,601$

İśāneśvara(bhaț̣āaka) Temple, 251

'ishk (divine love), 7, 8, 11

Islam, 6, 8-10, 14, 57, 62, 65, 68, 77, 484, 485

Islamic, 7, 9, 14, 60, 405, 431

Israel, 59

¿śvara / İ́sara, 30, 468

Íśvara (goldsmith), 249

Íśvaratattva / Iśvara Reality, 286, 287

Íśvaravarman, 383, 385, 387, 389, 533

Íśvaravāsaka, 321

ithyphallic, 489, 529, 548, 559, 561, 577-579, 581,598

Jābāla Upaniṣad, 470, 471

Jabalpur, 146, 150

Jacques, St, 53

Jaeschke, Walter, 24, 41, 43

Jagadindu, 290, 291, 294, 297

Jagatgram, 447, 448, 451, 452, 455

Jain(a), 50, 305, 412, 413, 425, 430, 435, 459, 529,578

Jaina canon, 49

Jain(a)s, 5, 320, 417, 477

Jainism, 51, 321, 413, 426, 437, 578

Jaipur, 356

Jaitrapāla, 89

Jalhana, 86, 160

Jami Masjid (Jaunpur), 384

Jambūdvīpaprajñapti, 51

Jambumārga, 295, 527, 528, 562-565

Jamkhedkar, A.P., 79-81, 113-115, 122, 125, $134,140,141,356,357,367,460$

Janaka's daughter, see Sìtā

Janakīīrtha, 341

Janamejaya, 248, 531

janapada, 48, 531, 569, 570

Janārdana, 406

Janasthāna (hermitage), 337

Janata Dal, 76, 77

Janssen, Frans, 461, 462

japa, 15, 288, 465, 470, 515, 531

Japan, 445

jatila, 490, see also matted hair

Jaunpur, 381, 533

Jaunpur Fragmentary Maukhari Inscription, 384

Jaunpur Stone Inscription of İ́varavarman, 381, 383-388, 395

Java, 411

Jayabala, 239

Jayabhatțāraka, 241, 256, 259

Jayacandra, 467, 484
Jayadeva, 530, 538

Jayadratha, 512

Jayadrathayāmala, 292-294, 296

Jayarāja (= Jayabhaț̣̄āraka), 241, 242, 245, 247

Jayaratha, 287

Jayaswal, Vidula, 377, 378

Jayeśvara, 265

Jayeśvarabhatțāraka, 239, 259

Jayeśvarabhațtāaka Temple, 239, 256

Jerusalem, 55, 71, 72, 551

jihād (holy war), 56, 60, 68, 69

jihvāmūlìya, 119

Jiṣnugupta, 531

Jiṭhān̄̄ Temple (Tālā), 256-260, 262-271, 273-280

J̄̄va Gosvāmīn, 52

jīvanmukti, 12, 13

jñāna, 286

jñānamudrā, 519

Jogeśvarī, 246

Jones, William, 27, 31

Jordaan, Roy E., 445, 447, 452

Joshi, J.P., 456

Journée des Aubépines, 52

Judaism, 57, 59

Junāgadh Rock Inscription of Skandagupta,

Years 136, 137 and 138, 132, 315, 388

Junagarh (Girinagara), 144

Junnar, 415

'just war' (bellum justum), 56, 481

Jvālāmukha, 387

Jyeșthavīrā, 419

$k a, 506,510$

Kabīr, 14, 16

Kabīr Bījak, 13

Kadalivana, 144

Kadalīvātaka (modern Kelāpur), 127, 144-147, 156, 157, 371, 414

Kadambas, 81

Kafle, Nirajan, 285

Kaimur Range, 391

Kākanādaboța, 321

Kākatīyas, 89

Kāla, 520

Kalacuri Samvat, 138, 142

Kalacuris, 142, 150, 561

Kālakarṇ̄, 532

Kālakūta (poison), 474

Kālāmukha, 12, 287

Kālañjara (mountain), 248, 253, 559

kalaśa, 490, 529

Kali Age / Kaliyuga, 107, 159, 291, 292, 295, 
$304,336,387,409,429,554$

Kālidāsa, 31, 51, 92, 130, 131, 151, 153, 156, $311,312,340,341,349,350,482$

Kālikā, 109

Kālikā Temple, 80

Kalinga(s), 236, 475

Kalipā (river), 92, 107, 108

Kalittokai, 168

Kaliyuga, see Kali Age

Kalpaśāstra, 410, 425

Kalpasūtra, 51

kāma, 243

Kāmadeva (king), 83-85, 165

kamandalu, 558

Kāmarūpa, 608

Kāmasūtra, 49

Kāmilu-t Tawārīkh, 482

Kamji River, 239, 241

Kamsa, 171, 316

Kamsavadha, 171

Kan̄āda, 294

Kanakhala, 605

Kanauj, 250, 381, 382, 394, 397, 421, 469, $482,483,527,528,532-534,538,553,563$

Kandhar, 460-461

Kane, P.V., 140, 409, 446

Kanișka, 415, 416, 426

Kaǹkāl̄̄ Mātā shrine, 570

Kan̉kālī T̄̄lā, 425

kañkana, 263

Kāntipurī (modern Kutwar), 302

Kanyakubja / Kānyakubja, 295, 381, 527, 528, 532-534, 553, 563-565, 601-603, 605, 606, 608, see also Kanauj

kanyās, 264

kapāla (skull), 287, 589, 594

Kapālasthāna, 602

kapālavrata, 287

Kāpālika(s), 293, 296, 599

kapardin, 594

Kapila (author Sāṃkhyasūtras), 29, 30

Kapila (ācārya), 328

Kapilā (river), 144

Kapilānda, 529

Kapileśvara (linga), 287, 328, 494

karāma (supernatural power), 10, 11

Kāravanamāhātmya, 297

karma $(n), 5,39,40,150,468,497,548$

karma-doctrine, 40

Karmānta Sūtra, 451

karmayoga, 36, 39

Karna, 593

karṇajāpa, 468, 471

karṇikāra (tree), 407

Kārohaṇa (modern Karvan), 287, 295, 297,
$494,528,529,553,554,563-565$

Karpūravāpī, 92, 93, 108

Kārttika, 108

Kārttikeya, 261, 604, 607, see also Skanda

Karttunen, K., 557

Karuka, 287

Kāruka (Pāśupata division), 287

Karvan, see Kārohaṇa

Kāsarapura, 87, 88

Kashmir, 70, 71

Kashmir Saivism, 543

Kāśī, 108, 464, 465, 484, see also Vārānas̄̄

Kāśs̄khạ̣̣a, 181, 467, 468, 469, 470, 471

Kaśyapa gotra, 354

Katha Upanișad, 227

Kathiawar, 388

Kathmandu, 186, 292, 469

Kātyāyana, 196

Kātyāyanaśrautasūtra, 450

Kaumārakhanḍa (Padmapurāṇa), 338, 339

Kaumudīmahotsava, 603

Kauṇdinya, 431, 496, 502, 513, 514, 516-518, $520,525,529,541-546,548-550,553,558$, $560,561,564$

Kauravas, 187

Kauruṣ(y)a, 287, 289, 527, 529-531

Kauśāmb̄̄, 253, 302, 306, 453, 455-459

Kauśika, see Kuśika

Kauśikī Cycle (Skandapurāna, SP), 400

Kaușitakibrāhmaṇa, 187, 190, 291

Kauṣitaki Upaniṣad, 60, 223

Kauṭilya, 467, 477

Kauvatal Plates of Sudevarāja, Year 7, 249

kavi, 85, 147, 151, 354, 601, 603, 607

kāvya, 127, 136

kāyasādhana, 13

kāyasiddhi, 13

Kāyāvarohana, 297

Kāyāvataraṇa (= Kārohaṇa), 529, 542, 553, see also Kārohaṇa

Kedārakhaṇda, 181

Kedāreśvara, 91, 106

Keesargutta, 453

Kelāpur, 144, 156, 371, see also Kadalīvātaka

Keśava (Kṛș̣a), 497

Kevala-Narasimha Temple (Ramtek), 80, 82, $115,143,147,163,345,351,355,356$, $357,365,413,414,434,435$

Kevala-Narasimha Temple Inscription (KNT), 80, 91, 92, 113-115, 117, 118-145, 310, $311,315,327,328,351-357,359,360$, $362,365,371,376,413,414$

Kevala-Narasimha Temple Ramtek Inscription No. 1, 83-86, 165

Kevala-Narasimha Temple Ramtek Inscrip- 
tion No. 2, 83, 86-88, 90

keyūra, 263

Khadirapadra, 251

Khalistan, 72

khanda, 181, 182, 184, 185, 469

khänkīh (monastery), 9, 10

Khairtal hoard (coins), 243, 244

Kharod, 249-251

Khilchipura, 569

Khindsi Lake, 91, 144, 145, 371, 372

Khmer, 400, 537

Kholeśvara, 86

Khusraw Khān, 90

Khwādja $\overline{M u} \times \bar{n}$ al-Dīn Čisht̄̄, 9, 11

Kielhorn, F., 88, 569

kīkasa, 421

Kippenberg, Hans G., 58, 60

kirāta (hunter), 522

Kirāta, 591, 592

Kirātārjunīya, 587-589, 592, 593, 597, 598

Kirfel, Willibald, 175, 179, 180, 182

K̄̄rti, 603

K̄̄rtivarman I, 142

kīrtti, 375

Kiskindhā, 48

Klaproth, J.H., 33

Kolte, V.B., 119, 145, 374

Konkan, 160, 415, 561

Konow, Sten, 395, 427

Koran, 6, 7

Kosala, see Dakșina Kosala

Kosalā, 243, 247, 249, 256

Kosalā (village), 239

Kośalakhanda, 182

Kosambi, D.D., 162

Kośīra, 250

Kośîra-Nandapura-vișaya, 250

kosthikā (storeroom), 400

Kotivarsa, 606

kramāditya, 140, 315

Kramrisch, Stella, 446

Kreisel, Gerd, 491-494

$k r \bar{\imath} d \bar{a}$ (play), 541, 550

Krishna District, 252

kriyā, 286, 293

Kropman, Martine, 332, 535

Krpa, 593

Krșna, 9, 16-21, 36, 38-40, 71, 128, 159, 161 , $163,164,167-171,173,174,316,375,376$, $478,480,481,497,512,550,551,556,557$, 588,604

Krșṇa (Sātavāhana), 415

Kṛ̦ṇa (Yādava king), 89

Krșna bhakti, 17

Krṣnadāsa, 140
Krsnakarnāmrta, 169

Kṛṣnakarṇāmṛtațīkā, 169

Kṛṇamiśra, 293

Krș̣narāja, 561

Krta Era, see Vikrama Era

Krtayuga, 90, 153, 154, 363, 554

Krtyakalpataru, 193

Krtyaratnākara, 193

kșatra, 65, 386, 534, 595

kșatrapa (incl. mahākșatrapa), 144, 301-303, 306, 373, 418, 419, 493

ksatriya, 55, 150, 152, 255, 407, 410, 411, 450, 476, 589

Kșemarāja, 285-289, 515

Ksemeśa (Rudra), 285, 287

Kṣemeśvara Temple, 383

kṣetra, 467, 471

kșetrajña, 225, 226, 228, 229

Ks̄̄rasvāmin, 51

Ks̄iratarañgin̄̄, 51

Ksupa, 534

Kubera, 406, 407, 585

Kuberanāgā, 138, 306, 323, 360-362, 414

Kuiper, F.B.J., 342, 343

Kujula Kadphises, 416

kula (family), 239, 240, 252, 294, 417, see also devakula

kulapati, 398-400

Kulkarni, L.R., 80, 88, 94, 338

Kulke, Hermann, 162, 301, 306, 311, 483

kumāra (prince), 415, 418, 605, 606

Kumāra, 264, 265, see also Skanda and Kārttikeya

Kumāra (or Kaṇāda), 294

Kumāragupta I, 51, 115, 140, 146, 155, 244, 308-311, 313-315, 320, 333, 359, 364, 375-377, 413, 414, 570

Kumārakas, 264

Kumārasambhava, 131

Kumārasvāmin (deity), 333, 375-377, 414

Kumbhāṇdas, 407

Kumhāra Tekḍ̄, 430, 560

kunda, 81, 339, 341

Kur (Giri?), 63, 64

Kurapadraka, 290, 291

kurgan, 419

kūrmaciti, 456

Kuru(s), 295, 527-531, 563

Kurud Plates of Narendra, Year 24, 243, 244

Kurukṣetra, 527, 528, 531-536, 563, 565, 602, 605

Kurukșetratīrtha (Ramtek), 91, 107

Kuśa, 93, 109

Kuṣāṇa, 49, 50, 156, 260, 415-417, 421, 440, $481,493,529,557$ 
Kuśika, 287, 295, 431, 494, 527-529, 541-543, 559-561, 564

kūta-yuddha (concealed fight), 476

kuti (hut), 425

Kutwar, 302

Lacey, Harriet, 150

Laganatola Inscription (AD 694/95), 539

laguda (club), 529, 554, 555, 558, 559

Lāguḍi, 295, 494, 527-530, 533, 537, 553-555, 558, 559, 561, 563, 564, 584, for his disciples, see four disciples

Lagudīiśvara, 559, 564

Lahore, 9, 313

Lajjā Gaurī, 462

Lakhneśvara (Lakșmaṇeśvara) Temple (Kharod), 249-251

Lakṣmaṇa (brother of Rāma), 93, 94, 110, 163

Lakṣmaṇa Temple (Ramtek), 80, 88, 89, 93, $94,165,166,338,339,347$

Lakṣmaṇa Temple (Sirpur), 245, 251, 253, 254,258

Laksmanasena, 484

Lakșmī, 107, 126, 140, 159, 247, 263, 311, $316,531,603$

Lakșmīdhara, 193, 468, 469, 533

Lakșmītīrtha (Ramtek), 91, 107

Lākudas, 559

lakula (club), 529, 584

Lakula/eśa, 286, 288, see also Lāguḍi, Lākulin and Lakulīśa(nātha)

Lākula (Pāśupata division), 286, 287, 295, 296

Lakulin / Lākuli(n), 528, 529, 554, 559

Lakulīśa(nātha), 287, 289-297, 494, 523, 529, $530,532,537,539,546,554,555,558-561$, $564,584,608$

lakuta, see laguda

Langlois, Alexandre, 32-34

lāingula, 559

Lan்kā, 48, 110

Later-Gupta, see Gupta(s), Later

laukika, 544, 553, 602

Lauriya-Nandangarh, 412, 417, 427, 429

Lava, 93, 109

Last Judgement, 8

laymen, 516, 517, see also laukika

Leiden, 373

Leiden University, 609

Leningrad Museum (St Petersburg), 315

Leontios, 547

Liber Sancti Jacobi, Codex Calixtinus, 53

Licchavi, 530, 531, 538, 608

Life of Symeon the Holy Fool, 547 lùla $, 8,18-20,52,61,171,550$

l̄̄lāsthala, 52

Līlāśuka Bilvamañgala, 169, 170

linga, 313, 319, 320, 328, 339, 401, 406 , 411, 413, 420, 421, 431, 437, 471, 472, 492-494, 496-499, 518, 521, 537, 545, $548,549,572,579,583,599$, see also ekamukha-, caturmukha-, svayambhulinga twelve lingas, 533

Lingapurāṇa, 186, 189, 192-199, 203 ff., 294, 559

Lingasambhūta, 520

Lingat, Robert, 150

Lingayasūrin, 129, 408

lion throne (simhāsana), 383, 385, 388, 389

logos, 543

Lokanātha (Viṣnu), 355

Lokapālas, 406, 407, 421

Lokaprakāśā, 239, 242, 243, 249, 256

Loksabhā, 76

Lolārka, 465, 467

Long, Bruce, 520

Lord, Albert, 176, 178

Lord of the Three Oceans, see trisamudranàtha

Lorenzen, David N., 62, 64

lotus-stalk (attribute), 522

Lucknow, 68, 69

Lüders, H., 328, 415, 416

Lunar Race / Dynasty (somavamśa), 239, 247-250, 283, 297, 536

Macchendranāth, 12

Madālasācampū, 86, 88, 163

Madana, 419

Madana (god of love), 401

Madanalobha, 81

madeleines, 53

Mādhāinagar Copper-plate Inscription of Lakṣmaṇasena, 484

Mādhavavarman II Janāśraya, 173, 174, 251, 252

Madhukara, 607

mādhurya-rasa, 21

Madhva, 18

Madhya Pradesh, 76, 150, 347, 563

Madhyamā / Madhyamikā / Mādhyamikā, 562, 567, 569-571, 598, 599

Madhyameśvara, 602

Mādhyandina śākh $\bar{a}, 354$

madhyaputa, 284, 285

Magadhā, 252, 397, 484, 534, 537-539, 564, $602,603,605,608$

Māgha, 325 
Mahā-Nārāyana-Upanisad, 545, 549

Mahābhairava, 93, 109, 157

Mahābhārata, 31, 47, 50, 179, 187, 189, 191-197, 199, 202 ff., 223, 230, 264, 265, 329, 375, 376, 400, 401, 409, 410, 429, $473,478,479,489-493,496-502,505,512$, $523,525,535,546,559,585,586,588,591$, $592,594,595,598,604,607$

Northern Recension, 524

Southern Recension, 516

mahābhūta (elements), 225, 226, 230, 231

Mahādeva, 89, 159, 163, 190, 466, 471, 489, 513, 514, 516-518, 523-525, 570, 591, 592, 598,599

Mahādeva Temple, 568, 572, 573, 595, 597, 599

mahādev $\bar{\imath}, 306$

Mahākāla, 496, 516, 517, 520, 602

Mahākālahṛdaya, 531

Mahākapāla, 602

Mahākośala, 244

mahākșatrapa, see kșatrapa

Mahāmantra, 464, 465, 531

Mahāmāyi Temple (Arang), 248

Mahāmāyūrī, 49

Mahānad̄̄ (river), 236, 240, 247, 255, 256

Mahānavam̄in, 149, 164

mahant (abbott), 12, 400

Mahānubhāva, 92, 94, 163

mahāpratīhāra, 397, 398

Mahāpuruṣa, 157

mahārāja, 154, 245, 397, 398

mahārājādhirāja, 154, 305-307, 321, 389, 438, 531

Mahārāshtra, 170, 173, 335, 418, 455, 460

Mahāśabda (five), 397

Mahāśaiva, 531

mahāsāmanta, 247, 249, 394, 397, 398, 538

Mahāsamayasutta, 407

Mahāsiddhi, 93, 109

Mahāśivagupta (Bālārjuna), 248, 251-256, 289, 290, 296, 297, 532

Mahāśmaśāna, 531

Mahāsthān, 453

Mahatma Gandhi, 55, 75, 76, 475, 477

Māhātmya, 183, 184, 534, 604, 605

Mahāvamśa, 428

Mahāvastu, 407

Mahāvideha, 49

Mahāvīra, 51

Mahāvrata (Great Vow), 291, 294

Mahāyāna, 255

Mahbubnagar District, 171

mahendra, 308

Mahendra / Mahendrāditya (king), 243-245,
308

Mahendravikramavarman (Pallava king), 293

Maheśa, 463, 464, 494

Maheśvara (Śiva), 154, 326, 330, 333, 406, $470,489,490,492,497,498,512,515$ $524,525,528$

Māheśvara(s), 287, 288, 321, 326, 329, 331, 494, 496, 543, 593, 602-608

Māheśvarakhaṇda (vulgate Skandapurāṇa), 186, 192-199, $203 \mathrm{ff}$.

Maheśvaranāga, 313

Maheśvarapura, 562, 563

Mahișāsuramardin̄̄, 320, 330, 333

Maḥmūd of Ghazni (Sultan), 62, 63, 73, 482, 483

Mạ̣mūd (prince), 483

Māhurjharī, 143

Māhurjharī Plates of Pṛthivīṣena II, Year 17, 325

Māideva (Māyideva), 89

Maikala Range, 157, 242

Mairāl family (Ramtek), 90

Maitrāyaṇīsaṃhitā, 449

Maitrāyan̄ìas, 449, 450

Maitrya, 529

Majhimikā, 569

Major, John, 56

Majumdar, N.G., 394, 412

Majumdar, R.C., 301

Majumdar, Susmita, 289, 290

makara, 260, 262, 263, 265, 273, 274, 568, 575

Makran Coast, 12

Malamoud, Charles, 411, 438, 439, 447

Mālava, see Malwa

Mālavā, 147

Mālavas, 302

Mālavikā, 312

Mālavikāgnimitra, 311, 312

Malgā, 249

Malgā Plates of Sāmanta Indrarāja, 240, 249

Malhar, 240, 242, 256, 294, 577-579, 582, 583

Malhar (Junvānī) Copperplates of Mahāśivagupta, Year 57, 289, 290, 296, 297, 532, 559

Malhar Plates of Jayarāja, 245

Malhar Plates of Śurabala Udīrnavaira, 238, 239, 259

Malhar Plates of Vyāghrarāja, 240

Mālinīvijayottaratantra, 285, see also Śrīpūrvaśāstra

Mallinātha, 130

Malwa, 119, 140, 160, 302, 305-307, 312, 316, 317 
Eastern Malwa, 302, 309, 310, 323

Western Malwa, 302, 307, 563, 570

Māmallapuram, 342, 413

Man of Mansar, see Manasarapuruṣa

Mānavaśrautasūtra, 449, 450

manas, 224-230

Manasarapuruṣa (Man of Mansar), 422, 423, 434, 435, 457, 458, 461, 462

Mạ̣daka, 249

mandala, 166, 460

Maṇdaleśvara, 400, 401, 403

Manduleśvara Māhātmya, 400

Mandaleśvarasvāmin, 398-400

Maṇdaleśvarasvāmin Temple, 400

mandapa, 83, 115, 329, 356, 365

Mandapesvar, 561

Mandara (mount), 342, 534

Mandasor, 307, 522, 532, 562, 573, see also Daśapura

Mandasor Fort, 569

Mandasor Inscription of Mālava Saṃvat 524, 307, 308

Mandasor Inscription of the Krta Year 461, 308

Mandasor Stone Inscription of Kumāragupta and Bandhuvarman, 119, 136

Mandasor Stone Inscription of Yaśodharman and Visnudharman, 127

Mandhal, 81, 138, 141, 146, 157, 259, 264, 282, 323-329, 333, 334

Māṇ̣hal Charter of Pṛthivīṣena II, Year 10, 146,325

Māṇdhal Plates of Pṛthivīṣena II, Year 2, 142, 325, 340

Māndhal Plates of Vākātaka Rudrasena II, Year 5, 323-326, 328-330, 361, 362

mangala, 352, 355, 383, 571

Maniārī (river), 256

Manikālakunda, 92, 108

Maṇikarṇikā, 467, 468, 473

Manimekalai, 411

Mann, Thomas, 548

Manorathasvāmin, 571

Mansar, 143, 157, 259, 331-333, 372, 373, 421, 422, 431, 432, 435, 438, 453, 455, 457, 459, 495, 496, see also Man of Mansar and MNS 2, MNS 3

Mansar (site T), 432-435, 438-440

mantra, 15, 446, 448, 464-468, 509, 518, 543, $545,549,594,595$

five mantras (Sadyojāta, etc.), 492, 513

see also Mahāmantra, Șaḍakṣara, Sāvitrī, Tāraka, Brahmaśiras

Mantramārga, 505

Mantrapītha, 284
Mantrarāja, 465

Manu, 47, 231

manujendraputrī, 133, 143, 354, 357, 358, 360,361

Manusmṛti, 27, 223, 478, 546, 559

Manusyaka, 529

Mārātha, 80, 90, 92

Maria Anna of Bavaria, 363

Maria of Spain, 363

Mārkaṇdeyapurāṇa, 473

Mārtāṇdamāhātmya, 193

Martin, Montgomery, 391

martyrdom, 60, 61

Marx, Karl, 26

Māsod Plates of Pravarasena II, Year 19, 324

Māt, 415, 416, 440

Mātan்aśāstra, 285

matha (monastery), 12, 399, 400, 403, 532, 602

mathikā, 296

Mathurā, 108, 156, 295, 415, 425, 492-494, 527-530, 554-557, 561-565

Mathura Museum, 529

Mathurā Pilaster Inscription of Candragupta II, Year 61, 287, 328, 413, 494, 502, 529, $541,558,561$

matrimonial / matrimony, 115, 140, 240, 305, $306,312,362,363,539,540$

Mātṛās (eight), 93, 109

mātrs (mothers), 265, see also Mātṛkās and Mothers

Matsyapurāṇa, 468, 471, 473

Mattavilāsaprahasana, 293

matted hair, 66, 490, 581, 589, 594

Matthew, 505

Maudā, 327

Maukhari(s), 250-253, 303, 381, 382, 386, $388,389,394,397,402,469,527,530$, $532-534,536,538,553,601,602,604$, 605,608

Maurya(s), 239, 311, 571

Mauss, Marcel, 4

Mausula(s), 286-288, 293, 295, 296

$m \bar{a} y \bar{a}, 8$

Mayamata, 520

Māyātattva / Māyā Reality, 284-287, 292

Mayrhofer, Manfred, 408

medha, 447

medhya, 447

megalithic, 409, 429

Megasthenes, 479, 480, 557

Meghadūta, 92, 340, 341, 376

Meister, Michael, 574

Mekalā, 147, 235, 237-240, 242-245, 247, $249,250,256$ 
Mekalapadraka, 250

memorial (temple), 378, 413, 439

memorial stones, 413, 417, 418, 439, see also chāy $\bar{a}^{\circ}$

mercury (rasa), 12

Middle Ages, 56, 166

Mihiraka, 249

Mihirakula, 598

Minnat Mian, 75

Mirashi, Vasudev Vishnu, 80, 86, 88-92, 94, $95,118,130,146,157,170,173,235,236$, 244, 315, 324, 325, 341, 368, 374, 375

Mīregāon Plates of Prabhāvatī Guptā, Year $20,314,332,354$

Mitra, 295, 527, 528, 562

Mitra dynasty, 562

Mlecchas, 483, 604

MNS 2, 331

MNS 3, 331, 332, 373, 374, 422, 423, 432, $434,435,455-457,495$

Moghul / Mogul, 65, 66, 478, 485

Mohallā Plate, 324-326, 329

Mohammed, see Muhammad

Mo-hi-shi-fa-lo-pu-lo, 562, see also Maheśvarapura

mokșa, 7, 12, 19, 308, 473

Mokșadharma (MBh), 223, 224, 227, 230-234, 479

Moksakunda, 92, 108

monastic orders, 12, 63, 513

monasticism, 9

'monda', 138

Mondasvāmin, 138, 326, 327, 329

monotheism, 6, 14, 15, 62, 72, 77

moon, $167,168,173,174$, see also candra

morality, 3, 40, 41

Mori Rajputs (Mauryas), 571

Mothers (seven), 320

Mothers (eight), see Mātṛkās (eight)

Mrgendratantra, 284

Mudgalīśa, 289, see also Mugalisa

Mūdhugi, 160

mudrā, 520

Mudrārākṣasa, 303, 603

Mugalisa, 289-291, 293, 296, 297

Muhammad, 8

Muhammad b. Tughluk, 9

Mu`īn al-Dīn, 9

Mukhara, 384, 386, 387

muktāyajñopavīta, 368

mukti (release), 18, 465

Muktīśvara, 93, 109

Mukundara, 573

munda, 491

Munda(s), 328
Munda (a brahmin), 328

Munda (king), 406, 408

Muṇāa, 126, 130, 137, 138, 310, 327, 328, 333, 358, 359, 361, 362

Munda-Śrn்khalika Pāśupatas, 294, 531, 532

Mundasvāmin, 326, 327, 329, 333, 361, 362

Muṇ̣eśvarī (goddess), 391

Muṇ̣eśvarī Hill, 393, 401, 403

Muṇdeśvarī Inscription of the Time of Udayasena, Year 30, 392, 394-396, 401

Muṇ̣̂eśvar̄̄ Temple, 391, 392

mundin, 491, 492

muñja grass, 510

Murāri (Viṣnu), 109, 110, 159, 338, 339

mūrti, 496, 505, 513, 514, 515, 516, 518

Murunda, 328

Mus, Paul, 445

musaladatta, 289

Musaleśa/īśa, 289, see also Mugalisa

Musée Guimet, 555

Musée Marcel-Proust, 53

music, 10, 15, 85, 296, 446, 520, 545

Muslim(s), 5, 7, 8, 10, 15, 16, 60, 62-66, $68-75,77,78,475,478,482-486$

Musțika, 171

Musula/eśa/endra, 286, 288, 289, 293, see also Mugalisa

Mutiny, see Rebellion of 1857

mysticism, 8

Nachna, 367

nafs, 7

nāga (serpent), 94, 311, 407, 409, 414, 438, 531

Nāga(s), 94, 138, 302, 305, 306, 309, 311-315, $323,326,328,332,360-363,414,438$

Nāga image, 433-435

Nāgabala, 238, 239, 245

Nāgabhațta, 313

Nāgadatta, 426, 427, 428

Nāganikā (queen), 415

Nāgarāja, 362

Nagardhan, 79, 141, 143, 150, 151, 155, 259, $330,341,342$, 344, see also Nandivardhana

Nagardhan Plates of Svāmirāja, 144

Nagarī (Rajasthan), 522, 523, 525, 562, 567, 569-572, 575, 578, 579, 581, 583, 588-590, $595,596,598,599$

Nāgarī script, 84

Nāgārjunakonda, 172, 417

Nāgasena, 302

Nagpur (Maharashtra), 79, 90, 149, 150, 157, $170,324,335,337,356,373$ 
Nagpur (Central Museum), 81, 151, 155, 355

Nagpur Plain, 79

Nagra, 81

Naigama, 571

Naigamesa, 264, 281, 282

Naikatungādhipeśvara, 537

Naimisa, 607

Nakulin, 559

Nakul̄̄śa, 283, 529

Nala(s), 142, 147, 173, 245, 256, 347

Nalacampū $, 85,86$

Nālandā, 602

Nalanda Clay Seal of Harșa, 531

Naliasar, 562

nāmajapa, 11

nāmakīrtana, 11

namāz, 75

Name (of God), 11, 14-16, 18, 465, 473

Name (RĀMA), 15, 94, 110, 464, 466, 474

Nanda, 20, 173

Nandapur(a), 250, 296

Nandapuri, 81

Nanded District, 460

Nandikeśvara, 261

Nandin, 261, 496, 516, 517, 518, 520

Nandivardhana, 79, 141-143, 146, 147, 150, 306, 309, 314, 325, 329-332, 340, 364, see also Nagardhan

Nāṇeghāṭ, 415, 416, 440

Nannarāja I (son of Indrabala), 240, 247-251

Nannarāja II, 253

Nara, 497, 581, 588-590, 599

Nara-Nārāyaṇa, 589

Nārada (seer), 336

Nāradasmrti, 141

Narain, A.K., 322

Narasiṃha (Vișṇu), 80, 81, 83, 85, 90, 93, $106,109,128,134,135,143,144,155$, $156,158,160,163,165,254,261,265$, $333,334,343-349,353,355,356,365,372$

Narasingha (son of Bota), 239, 256

Narattañgavāristhāna, 325

Naravarman, 308

Nārāyaṇa, 160, 196, 320, 322, 327, 398, 497, $581,588-590$

Nārāyana Vātikā, 570

Nārāyaṇa Temple, 400

Nārāyaṇabhațta, 467

Nārāyaṇadevakula, 397

Narendra (mahārāja), 243, 244

Narendrasena, 146, 147, 244, 324

Narmadā (river), 174, 302, 306, 312-315, $317,364,388,498,563$

Nasik, 74

natarāja, 545
Nāth cult, 13, 16

Nāth Yogis, 12, 13, 17

näths (nine), 11

National Archives (Kathmandu, Nepal), 180, $194,292,469$

National Museum (New Delhi), 492, 495496 , 580

National Museum Kathamandhu Stone Inscription of NS 264, 534

National Museum of Afghanistan, 555

Navarātra festival, 482

nawābs of Avadh, 66

Neapolis, 547

Nemeian Lion, 556, 557

neolithic, 439

neophyte, 508

Nepal, 185, 413, 431, 530, 531, 534, 537-539, 602,608

Nepal-German Manuscript Preservation Project (NGMPP), 185, 194

Nepāla, 608

Nepalese recension (S recension of SP), 471, 472, 537, 608, 609

Neuss, Jürgen, 393, 394

New Indo-Aryan, 175

New Jerusalem, 71

Nhāṇi Sīteci, see Sītec̄̄ Nhāṇ̄̄

Nibandha, 469

Nidilā (river), 241

Nigam, L.S., 261

Nīlakaṇtha, 191

nìlalohita, 190

N̄̄lalohita, 589, 594

Nīlamatapurāṇa, 193

Nimbārka, 18

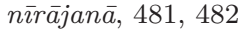

nirguna, 14, 16

Nirṛti, 492

nirukti, 467, 471, 489

Nișthurarāja, 236

Nisunda, 400

Niśvāsamukha, 285, 559

Niśvāsatattvasaṃhitā, 285, 559

Niẓām al-Dīn Awliyā, 9, 10

Norman, K.R., 121

Northern Black Polished Ware (NBPW), 571

Nrhari, see Narasimha

Nrsimha, see Narasimha

Nrsimhatīrtha, 91, 107

Nrsimhavarman I, 413

Nuh Sipihr, 90

numismatics, 373, 609

Nyāya, 518

Nyāya-Vaiśeșika, 28, 29 
Oberhammer, Gerhard, 37, 514

Oberlies, Thomas, 546, 553, 554

Obeyesekere, G., 164

ojas, 354

Old Testament, 58

OM, 38, 127, 468, 515, 549

On̄ī District, 291

oral composition, 176

oral tradition, 175, 177, 178, 184, 199

Oriental Despotism, 24

Oriental Institute in Vadodara, 283

orientalist, 470

Orientalism, 31

Orissa, 155, 253, 402, 608

Orthodox Church, 60

Oshibat, 437

Otto, R., 58

Pābūjī Rāthaur, 177

pada, see footprint

pādamūla, 330, 340, 343

Padana Hill (Bombay), 289

Padmapura, 141, 324-327, 332

Padmapura District, 324, 328, 329

Padmapurāṇa, 338, 466

Padmāvatī (modern Pawaya), 302

Pakistan, 11, 70, 71, 72, 426, 437

Pāli canon, 49

Pallava(s), 252, 259, 260, 293, 413, 417, 522

palli-patai, 413

Pāñcarātra, 16

Pañcārtha doctrine (Pāśupata), 286-288, 295, 296, 528, 533, 563

Pañcārthabhāṣya, 541, 553, 578

Pañcārthapramāṇa, 286, 287, 541, 563

pañcaśikha, 190, 197

Pañcavaț̄i, 337

Pāndava Kingdom, 296

Pāṇ̣avas (sons of Pāṇḍu), 585, 588, 595, 596,598

Pāṇdavas of Kosala, 235, 238, 239, 247, 248-255, 289

Pāndavas of Mekalā, 235, 237-239, 243, 247-249

Pāṇdhurṇā Plates of Pravarasena II, Year 29, 323, 332, 354, 503

Pāndụ, 239, 248, 601

Pāṇḍvamśrin(s), 532, see also Pāṇḍavas

Pāṇini, 49, 196, 407

pānipātrika, 321

Panjab, 48, 71, 483, 570

Pañktiratha (= Daśaratha), 93, 109

pāpa, 480
Pāragārgya, 529

paramabhāgavata, 243

paramabhatțāraka, 244, 531

Paramadhāna Āśrama, 170, 171

paramamāheśvara, 154, 255, 531, 606

Paramānanda-Sāgara, 20

paramavaisnava, 255

Parameśāna, 192, 559

Parameśvara, 401, 492, 594

paramparā, 291, 293, 297, 529, 561, 564, 584

parāmukti, 13

Pāraskaragṛhyasūtra, 509

Paraśurāma, 180

Pārāvata, 607

parigraha, 516, 518, see also grace

Parīksit, 248

Paris, 32-34

Parṇadatta, 144

Parry, Milman, 176

Parry-Lord theory, 175, 176, 179

Pārśvanātha, 320

pārśvasūtra, 405

Parthian, 417

partition, 70, 72

Pārvatī, 131, 186, 191-193, 201, 471, 474, $586,591,595$

pāśa, 263

pāśajāla (net of bonds), 285, 292, 532

Pāśipadraka, 291

paśu, 446, 449-451, 481, 515, 545, 550

Pāśupata(s), 12, 283, 284, 286-288, 292, 293, 296, 297, 397, 403, 430, 472, 494, 496, 498, 505, 513, 515-517, 525-528, 530-534, $539,543,544,546,548-551,553,554,557$, 561-563, 565, 578, 586, 587, 590, 593-595, 598, 599, 602-605, 608

Pāśupata Saivism, 283, 284

Pāśupata weapon, 512, 523, 526, 593, 594-599

Pāśupata yoga, 525, 527, 542, 558, 560, 563, 583, 584, 594, 606

Pāśupatanāth, 431

Pāśupatāstra, see Pāśupata weapon

Pāśupatasūtra, 286, 287, 431, 496, 502, 513, 514, 516, 518, 529, 541, 543, 545, 549, 553,558

Pāśupatavidhi, 559

pāśupatavrata (Pāśupata observance), 514, $524-526,559,576$

Paśupati(nātha), 190, 413, 530, 537, 539, 542, 544, 561, 563, 602, 608

Paśupati Temple Inscription, [Aṃśuvarman] Samvat 157, 538

Paśupatinātha Temple (Nepal), 294, 530, 531,539 
Pātagaṇdigūdem Copper Plate of Ehavala Cāntamūla, 325

Pātaliputra (modern Patna), 51, 137, 302, 319, 408, 537

Patañjali, 49, 569

pati, 545

Patil, D.R., 417

Patna, 85, 137, 138, 302, 391, see also

Pāṭaliputra

Patna Museum, 407

patronage, 155, 162, 255, 319-323, 332, 333, 402, 602, 603

Paul, St, 546

Paümacariya, 51

Paunar, 141, 170-174

Paun̄̄, 326, 418

paurānika, 178, 471

Pawaya, 302, 370, see also Padmāvat̄̄

Pax Britannica, 55

Pazyryk, 419

Periyālvār (Viṭtucittañ), 167, 168, 174

Persian, 66

person (concept of), 3, 4, 20, 21, 28, 29, 40

Peshwa, 90

Petersburg, St., 140, 315

Phalgudeva, 419

phallic, 489, 493, 496, 555, 559

phallus, 489, 496, 497, 498, 514, 516, 545, 578 , see also linga

Phillip II, 363

Piano, S., 346, 349

picchika, 578

pilgrimage, 62, 65, 72, 85, 162, 347, 403, 467, 550,606

pillaitamil $, 167,168$

Pināka, 490

pinda, 325, 405

piñdāra, 401

Pindāraka, 401

Piṇdāreśvara, 401

Pine Forest, 579, 599, see also Devadāruvana

Pingala, 529

Pīpardūūā Copper-Plate Inscription of King Narendra of Śarabhapura, 243

Piprawa, 412

pīr, 10, 12

Piśāca(s), 593

Pītakeśa, 134

Pitāmaha, 406

pitha, 263

pitr $(s), 492$

pitrtarpana, 91

Pitrtīrtha (Ramtek), 91, 107

polytheism, 56, 62, 152

polytheism thesis, 56-59
Poona Plates of Prabhāvatīguptā, 118, 119, 138, 240, 314, 329, 330, 438

post (wooden), 417, 427, 446, 458, 489

Posthomerica, 176

Prabhākara (bhūmipati), 307, 308

Prabhākaravardhana, 405, 421

Prabhāsatīrtha, 294

Prabhāvatī Guptā, 80, 113-115, 118, 133, $137-142,145,150,154,155,240,301$, 306, 309-312, 314, 317, 323, 325, 327-334, $340,343,344,352,354,355,359-364,371$, $376,413,414,432,438$

Prabhāvatisvāmin, 80, 126, 133, 137, 143, $144,156,328,333,343,354,355,357$, $364,365,371,372,376,378,413,414$

prabhutva, 542

Prabodhacandrodaya, 293

Prabodhin̄̄ Ekādaśs, 330

pradakșināa $/ a, 401,407,482$, 509, 511

pradaksinapatha, 393

pradhāna, 228

prādurbhāva, 50

Pradyumna, 253

Prahasiteśvara linga, 537

Prahlāda Ghāt, 534

Prajāhita (aid̄̄ka), 406

Prajāpati, 188, 190, 193, 292, 451, 506, 507, $508,509,510$

prajña, 224

Prakāśadharman, 571, 588, 589

prakāśa-yuddha (open fight), 476

prakata, 71

Prakrit, 327

prakrti, 30, 228, 229

Pramāṇa (texts), 286, 288, 292

Pranardanaprāṇa Kauśika (Pāśupata teacher), 531

pranava, 468, see also OM

prasāda (grace), 18, 153, 154, 160, 161, 165, 498, 542, 583, see also grace

prasāda (sacred food), 52

prāsāda (temple), 143, 156, 413

Prasannamātra, 242, 244, 245, 260

Prasannapur, 241, 242, 245, 249

praśasti, 146, 252, 304, 324, 352, 354, 357-361, 363

prāśitra (fore-portion), 187, 188, 190

Pratīhāra, 532

pratima $, 375,376$

pratimāgrha, 377, 411, 413, 415-417

Pratimānātaka, 410, 411, 415, 416

Pratismrti, 585

pratyantanrpati, 302

Pravara I (= Pravarabhațtāaraka), 241

Pravarapura, 141-143, 325, 331, 332, 364 
Pravararāja, 247

Pravarasena I, 152

Pravarasena II, 114, 115, 134, 141, 142, 145-147, 150, 154, 301, 314-316, 324, 325, 330-333, 352, 354, 360, 361, 363, 364, 371, $372,432,438,495$

Pravareśvara, 157, 331-334, 374, 495, 496

Pravareśvara Temple (Mansar), 372, 373, 432

Pravareśvaradevakulasthāna, 495, 496

Prayāga, 142, 302, 306, 602, 606, 607

Pregnant women, 412, 424

prema-bhakti, 14

preta, 405

Prītikūta (village), 536

Priyadarśikā, 607

Prolegomena (of SP edition), 185, 186

prophet, see Muhammad

Proust, Marcel, 47, 53

Prthivipura, 142, 143

Prthivisamudra, 142, 143, 325

Pṛthivīṣeṇa I, 154, 323-325

Pṛthivișena II, 142, 143, 146, 147, 173, 325, 326,332

Prthivivigraha, 236

Pṛthvīrāja, 483

Przyluski, J., 559

pseudo-Śamkara, 519

Ptolemaeus, 49, 556

pūjā, 255, 467

Pundra, 606-608

Punjab, see Panjab

Purānas, 179-182, 184, 193, 194, 198, 199, 283, 284, 294, 401, 407, 464, 468, 469, 473, 474, 604, 606-608, 610

Purāna of Skanda, 403

Purānapañcalaksana, 47, 176, 179, 190

Purī, 63, 64, 108

pūrnakalaśa, 580, 581, 595

purodāśs, 579

Purohita, 531

Pūrugupta, 314

purusa, 29, 94, 422-424, 444, 446, 447. 449-451, 457, 460, 517, 542, 563, 584, 589

Puruṣa Hymn (Rgveda X.90), 444, 449

purusaciti (man-layer), 449

Purusamedha, 447, 454, 455, 462, see also human sacrifice

Purușasāman, 448, 450

purusaśiras, 449

Puruṣottamakṣetramāhātmya, 184

Pūṣan, 188, 189, 195, 196

Puṣkara, 528, 562, 563

Pușkarī, 142, 245, 347

Puspaka, 336, 529, 530
Puspadanta, 321

pustaka, 606, 607

pustakavācaka, 178, 607

Pusyabhūti(s), 528, 531, 536, 602

Pusyagupta, 144

Pusyamitra(s), 311, 315

Quintus Smyrnaeus, 176

Qutb al-Dīn Aybak, 484

RA recension of SP, 469-473, see also Skandapurāna (SP)

Rabatak inscription, 416

Rabatak Temple, 416

Rad, G. von, 58, 59

Rādhā, 550

Rāghava (brother of Trivikrama), 87, 88, 90, 163

Rāghavadeva, 89, 105

Raghavan, V., 303

Raghu, 164, 482

Raghuji (Bhonsle), 356

Raghunātha Prasāda, 66

Raghupati (Rāma), 340, 341, 343

Raghuvamśa, 51, 130, 151, 388, 482

Raipur, 253, 347

Raivataka (mountain), 388

rājadharma, 322

Rājādhirāja II (Cola king), 294

rājanya, 450

Rajaona, 595, 596

Rājapraśasti (in CVC Vratakhanda), 159

rājarși, 128, 138, 352, 358, 359, 361

rajas, $224,228,386$

Rājaśekharasūri, 529

Rajasthan, 522, 562, 563, 567

rājasthānīya, 571, 598

rājasūya, 150

Rājāȳi, 89, 105

Rajgir, 429, 595

Rajim, 245, 251, 256, 346

Rājīvalocana Temple (Rajim), 251, 256, 346

Rajpur, 75

Rajputana Museum (Ajmer), 570

Rajuvula, 557

Rājyaśrī (Lakșmī), 531, 536

Rakṣas / Rākșasa, 93, 265, 498, 593

Rām Sāgar, 92, 144

Rāma (Rāmacandra), 9, 14, 16, 21, 48, 50-52, 61, 64, 65, 71, 73, 75-77, 83, 84, 86-88, 90, 91, 93, 94, 106, 108, 110, 111, $128,161,163-165,173,335-340,343,347$, $376,463-467,474,498,550$ 
RĀMA, 14, 16, 94, 467

Rāma (general), 86

Rāma bhakti, 19, 52, 465

Rāma Navamī, 66

Rāma rājya, 64, 71, 72, 75, 77, 336, 485

Rāma-Krsna Temple, 91

Rāma's Birthplace, see Rāmajanmabhūmi

Rāma's footprints, 92

Rāma's Hill, see Rāmagiri and Ramtek

Rāmacandra (Yādava king), 88, 89, 93, 94, 105, 109, 159-161, 163, 164

Rāma(candra) Temple (Ramtek), 166, 339, 347

Rāmacandra Temple (Rajim), 245, 246

Rāmacaritamānasa, 64, 65, 463, 464

Rāmadeva, 111

Rāmagayā (Rāma's Gayā), 91, 108

Rāmagiri, 79, 90-92, 141-145, 147, 155, 166, $325,329-335,337-343,346,347,349,351$, $356,357,363,365,366,368,370-372,378$, 413, 432, 434, 435, 438, 455, see also Ramtek

Rāmagirisvāmin, 143, 330, 333, 340, 341, 343

Rāmagupta, 302-307, 321

Rāmajanmabhūmi, 65, 68, 71-73, 75-77, 337, 485

Rāmakaṇtha, 287

Rāmakathā, 50

Rāmānanda, 468

Rāmānuja, 8, 17, 18

Rāmarājya, see Rāma rājya

Rāmatīrtha, 92, 108

Rāmāyaṇa, 25, 39, 47, 48, 50, 64, 65, 71, 72, $77,93,94,170,179,335-341,350,376$, 465, 498, 502, 604

Rāmeśvara linga, 498

Ramgarh, 391

Rāmottaratāpan̄yopanisad, 466

Ramtek (Hill), 79, 80, 81, 85, 90, 94, 113, $114,144,149,151,155,157,158,163$, 165, 166, 259, 314, 337, 340, 341, 349, 351, 356, 455, 495, see also Rāmagiri

Ramtek Stone Inscription of the Time of Rāmacandra, 88-111, 144, 145, 337, 338

Rann of Cutch, 419

Rao, Gopinath, 519, 520

rasa (liquid), 589

rasa (emotion), 19, 334

rasa (tanmātra), 225

rasa (mercury, elixer), 12, 451

Rasārnava, 12, 18

rasāyana (alchemy), 12

Rashkān, 20

${ }^{\circ}$ rāsi, 532

Rāśi branch (of Pāśupata), 532
Rasika (sect), 52

Rāsiskara, 529, 531, 532

Rāștrakūṭa, 304, 461

Rastriya Svayamsevak Sangh (RSS), 72, 73

Ratnarāśi, 532

Ratnatīkā, 513-515, 518, 531

Ratnāvalī, 607

raudra, 490, 593, 594

Raudra Weapon, 593

Rāvana, 93, 108, 110, 339, 498

Raven, Ellen, 305, 309, 315, 609

Rawan Plates of Maharaja Narendra, 243

Rāyamukuṭa, 130

Raykwar, G.L., 261, 289

Rebellion of 1857,70

rebirth, 5, 19, 38, 39, 41

Red Polished Ware (RPW), 571

reification, 50, 52, 71

relic(s), 407, 408, 425, 427, 439, 440

renouncer, 4,498

renunciation, $7,55,425$, see also samnnyāsa

Republic of India, 70

Revā, 174, 388, see also Narmadā

Revākhaṇda ( $\mathrm{R}$ recension $\mathrm{SP}), 185,469$

Revākhạ̣da (vulgate Skandapurāṇa, SkP), 185

Revelation, 9

revelation, 197, 541, 543, 544, 599

Rewa, 248

Rgveda/ic, 342, 354, 443, 444, 446, 509, 510, 517

Riddhapur Plates of Prabhāvatīguptā, 314, 330,340

Riesebrodt, M., 75

right side, 506-512, 514, 516-518, 520, 523

Rishikesh, 490

Rithapur Plates of Bhavadattavarman, 142

Rock-Edicts, Thirteenth, 475, see also Edicts

Rohitāgiri, 335, 402

Rohtasgarh, 391, 402

Romanticism, 25, 26, 43-45

rosary, 519, 581

Roth, Gustav, 407, 437

Route National No. 7, 149

royalisation, 161, 164

Rșabha, 51

Rsabhadeva, 419

rssi, 489, 497, 516, 519, 554

RSS, see Rastriya Svayamsevak Sangh

Rtuparṇa (king), 48

Rtusamhāra, 31

Rudra(s), 188-191, 193, 196, 197, 264, 292 , 496, 497, 516, 517, 520, 529, 532, 544, 548,585

eight, 285, 291, see also Vigraheśa 
twelve Rudras, 284-286

thirty-eight Rudras, 292

sixty-six Rudras, 290-293, 532

Rudra worlds, 284-288, 292, 293

Rudra-Narasiṃha Temple (Ramtek), 81, 143, 344, 345

Rudra's birth, 193

Rudradāman I (mahākșatrapa), 419

Rudradeva (Kākatīya king), 89

Rudrapurusadatta, 418

Rudrasena II, 114, 115, 126, 131, 136-141, $143,145,146,150,301,306,310,311$, 323-326, 329, 330, 332, 344, 358-363

Rudrasena III, 302, 303

Rudrasimha I (Śaka ksatrapa), 144

Rudraśiva ( $\bar{a}$ cărya), 534

Rudrasoma, 290, 291

Rudrayāmala, 182, 184

rūh (higher soul), 7

Rule of Rāma, see Rāma rājya

rūpa, 225, 514, 516, 518

Rupiamma, 418

Russian Orthodox Church, 548

S recension, 473, 537, see Skandapurāṇa, SP

Sa‘ādat Khān, 66

śabda, 225, 543

śabdabrahman, 15, 543

$\Sigma \alpha \gamma \tilde{\omega} \delta \alpha, 49$

sacrifice, 188-190, 444, 445, 448, 458, 481, $510,511,524$, see also construction, domestic, horse, human and Vedic sacrifice sacrificer, 448, 449, 451, see also yajamāna sacrificial, 342, 354, 387, passim

sacrificial fire / altar, 190, 387, 399, 447, 456, $482,505,508-512,543$

sacrificial victim, 445-447, 449-451, 475, 481

Sadakșara (six-syllable) mantra, 465-468

Sadāśiva, 492, 493, 549, 550

Șaḍdarśanasamuccaya (Haribhadra), 529

Ṣaḍdarśanasamuccaya (Rājaśekharasūri), 529

sadguru, 13, 16

sādhana, 17, 541, 584, 587, 595

Sādū Mātā, 570

sadyojāta, 545

Sadyojāta, 492, 513

Sadyojyotis, 287

Safì al-Dīn of Uch, 11

saguna, 16

sahaja, 13

Sahajiyā, 13, 17

Sāhasāṅka, 303

Sahl Al-Tustarī, 8
Śaiva, 66, 239, 283, 292, 313, 431, 464-468, 492-494, 531, 549, 555, 559, 590, passim

Śaiva Āgamas, see Āgamas (Śaiva)

Śaiva centres, 93, 422, 464, 473, 539, 562, 564,606

Śaiva monuments, 261, 320, 400, 494, 520, 561

Śaiva mythology, 186, 420, 534, 548, 598

Śaiva religion/movement, 283, 296, 326, 402, 464, 492, 550, 598

Śaiva sculpture, 329, 422, 492, 493, 496, 523, 529,586

Śaiva Siddhānta, 284, 288, 291, 296, 493, 534,543

Śaiva texts 465, 467, 468, 505, 546

Śaivala mountain, 336-339

śaivala (water plant), 336

Saivism, 12, 196, 284, 293, 321, 464, 550, 553, 594, see also Āgamic, Kashmir and Pāśupata Saivism

Śaka(s), 302, 303, 305, 306, 418, 419, 440, $481,557,558,562$

Śākambharī, 562

Sāketa, 49-53, 302

Sāketa-Ayodhyā, 53

Śākha, 264

Śakra (Indra), 187, 189, 191, 264, 406, 407, 498

Śākta Tantras, 16

śakti, 162, 434

Śālīki, 450

sam $\bar{a}$ ‘, 10

samā dhi, 405, 431

sāmanta, 240, 247-249, 322

Samantapañcaka (= Kurukșetra), 535

Sāmaveda, 509, 510

samayadīkșā, 515

Sāmba (Āditya), 329

Sāmbapurāna, 193

Sambhar, $5 \dot{6} 2$

Śambhu (Śiva), 154, 319, 464

Śambuka / Śambūka, 93, 109, 336-339, 350

saṃdhyābhāṣa, 463

samgamagrāmaka, 256

Samgītaratnākara, 85

Śạ̣kara (Śiva), 187, 191, 192, 197, 295, 466, 497, 516, 582, 592

Śamkara (philosopher), 7, 8, 37, see also pseudo-Śamkara

Śamkaragana, 561

Saṃkarșaṇa, 163, 329, 556, 570

Sāṃkhya, 28-30, 44, 223-225, 227-231, 285

Sāṃkhya-yoga, 524

Sāmkhyakārikās, 29, 30

Sāṃkhyasūtras, 30 
saṃnyāsa (renunciation), 5, 21, 55

saṃnyāsin, 63, 66, 491

samrāj (emperor), 152

samskāra, 514

Samskāravidhi, 559

samudgayamaka, 83-86

Samudragupta, 51, 138, 244, 302, 303, 305, $314,317,321,323,326,328,359$

Samudrapura, 142

Saṃyuttanikāya, 49

Sanakānika, 320

Sanatkumāra, 192

Sanchi, 321, 431

Sāñchi Stone Inscription of Candragupta II, Year 93, 308, 321

Sanderson, Alexis, 250, 285, 292-294, 397, 531,553

Śāṇịlya gotra, 85, 86, 328

sañgha, 61

San்gha (Buddhist), 321, 330

Sangsi, 418

Sankalia, H.D., 48

śankha (conch), 94, 110, 342

Śankha, 93, 94

Śaṅkhapāṇin (Viṣnu), 110

Śankharāma (Ramtek), 94, 110

Śankhatīrtha (Ramtek), 91, 106

Śānkhāyanagṛhyasūtra, 509, 511, 512

Sanskrit, 19, 27, 154, 527, passim

Sanskrit inscriptions, 80, 83, 113

Sanskrit language, 29, 31, 32, 33, 35, 198, $354,395,408,413,603,605,608$

Sanskrit literature / texts, 9, 19, 27, 32, 33, 49, 64, 152, 168-170, 174, 175, 186, 195, 335, 358, 405-407, 410, 430, 452, 458, 460, 481, 493, 496, 499, 505, 544, 604

Sanskritisation, 155, 158

Santāna, 529

Śāntanapura, 236

Santiago de Compostela, 53

Śāntikarma, 409

Śāntiparvan (MBh), 223, 230

Sant movement, 14

Sants, 11, 13-19

Sapādalakșa, 562

sapinda, 140, 146, 147

Śarabha, 243, 244

Śarabhapur, 235, 240, 242-245, 247, 249

Śarabhapurīyas, 240-245

Sārasvata, 535, 536

Sarasvatī, 65, 83-85, 264, 405, 463, 534-536, 603, 605-607

Saray $\bar{u}, 48,50$

sarcophagus, 425

Sarjū, 48
Sarkar, H., 418

Sārnāth, 575

śārnga / Śārnga (bow), 375

Śārngadeva (king, son of Kāmadeva), 83-85, 88,165

Śārngadeva (author of the Saṃgītaratnākara), 85

Śārṅgapānì (Viṣnu), 107, 161

Śārǹin (Viṣnu), 375, 376, 377, 414

Saromāhātmya, 583

sarpa, 448, 449

sarpaśiras, 449

Sarpasenaksamana, 321

sārūpya, 411

Śarva (Śiva), 190

Śarva (Rudra), 285

Śarvanātha, 328

Śārvarin-year, 84, 85, 165

Śarvavarman, 253, 397

Śaśāinka (Moon), 605, 606

Sastri, R. Ananthakrishna, 553

Sātakani/Sātakarṇi (king), 415

Śatānīka, 248

Śatānīka II, 248

Śatapathabrāhmaña, 188, 190, 353, 354, 446, 450, 451, 506-510

Satara District, 173

Sātavāhana(s), 138, 326, 373, 415, 418

Sātavāhana (kumāra), 415

sati, 405

satī-stones, 413

Satna, 253

Satpura Range, 149, 157, 306

satputra, 146

Śatruñjaya (mount), 413

Sātṭhapadrakagrāma, 250

Satțilādvādaśn, 325

sattva, 224, 225, 228, 229

Sātvata (school), 328, 329, 333

Satyasoma, 293

Satyaśūra, 570

saumya, 490, 492

Sauptikaparvan (MBh), 189

Saurashtra, 294

saving mantra, see tāraka mantra

Savitr, 187-189, 506, 507, 509

Sāvitrī (mantra), 506-509, 511

Sāyaṇa, 492, 493, 507

Scheuer, Jacques, 496

Schlegel, August Wilhelm, 31-34, 36, 43, 44

Schlegel, Friedrich, 25, 26, 31-33

Schlingloff, Dieter, 455

Schmidt, Hanns-Peter, 477

Schopen, Gregory, 427

Schopenhauer, Arthur, 26 
Schreiner, Peter, 224

scroll-work, 263, 382, 395, 398

Scyths, 419, 481

sealing, 140, 244, 373, 374, 495

seers, 109, 126, 127, 336, 409, 444, 497, 581, $586,588,589,591,598,599$, see also rsi

Seleucus, 479

self, 4, 7, 21, 224, 227-229, 544, see also $\bar{a}$ tman

-Sena, 313

Senas, 484

Senakapāt Inscription of the time of Sivagupta Bālārjuna, 250

senāpati, 264, 311, 312, 535, 606

senses, see indriya

serpents / snakes, 7, 93, 94, 110, 262, 311 . $319,326,361,386,414,423,433-435,438$, 449, 450, 454, 457, 458, 531, 581, 592, 593, 603, see also nāga, sarpa

Śesa, 94

Setubandha, 314

Sevnāth (river), 240, 256

Shah, Priyabala (U.P.), 406, 408

Shahdol District, 237, 249, 253

$\operatorname{shar} \bar{\imath}^{\prime} a, 10$

Sharma, A.K., 456

Sharma, G.R., 453, 454, 455

Sharma, Meera, 393

Shastri, Ajay Mitra, 113-115, 118, 133, 134, 235, 236, 242, 244, 251, 252, 289, 290, $325,373,374,378,415$

Shekhar, Chandra, 77

Shiite, 66, 69

Shirodkar, Dr, 462

Shivaji, 478

Shivaji Festival, 478

Shrimali, K.M., 157

Śibi-janapada, 569, 570

Siddha(s), 497, 516, 519, 539

siddhadeha, 12

siddhamusala, 289

siddhas (eighty-four), 11

siddhasthāna, 602

Siddheśvara, 91, 106

siddhi, 11, 108, 583

signet-ring, 309, 311-313, 316

Sihadeva, 49

Sikar, 562

śikhara, 166

Sikhs, 5, 71, 72

Śìlavarman, 452

Śilpaśāstra(s), 435, 460

Siṃaṇa (king), 83-86, 88, 89, 105, 158, 159, 165

Simhavarman, 308
Simuka Sātavāhana, 415

Sindūragiri, 79, 90, 91, 94, 106, 108, 109, 111,372

Sindūragirimāhātmya, 90, 144, 338-340, 372

Sindūravāpī (Ramtek), 92, 93, 108

Sindursi, 347-349

Singh, Purushottam, 429

Singh, Rahul Kumar, 261, 289, 290, 296, 297

Singh, V.P., 76

Sinha, B.P., 252

śipivișta, 196

śiraścakra, 368

Sircar, Dines Chandra, 236, 241, 242, 244, 375-377, 382, 383, 388, 494, 570

Siriämtha, 531

Sirpur, 240, 245, 247, 251, 252, 254, 258, 293 , 348, 349, 532, see also Śrīpura

Sirpur copperplate hoard, 296

Sirpur Stone Inscription of Śivagupta Bālārjuna (in the Gandharveśvara Temple), 248

Sirpur Stone Inscription of the Time of Mahāśivagupta (i.e. Vāsațā's Inscription in the Laksmana Temple), 253, 397

Sirsa (Haryana), 532

śișta, 542

śișa, 584

Sìtā, 73, 94, 108, 110, 111, 337, 340, 466, 550

Sìtākunda, 341

Sìtecī Nhāṇī, 92

Śiva, 12, 13, 86, 109, 186, 187, 189-199, 239, $291,293,294,296,319,320,332,338$ $381,401,411,419,420,463-467,470$, 471, 474, 489, 490, 492-494, 497-499, $514-522,524,526,528,530,532,534$, 543-545, 548, 549, 553, 554, 559-561, 563, $564,571,573,578-584,586,587,589-591$, $593,595,598,602,604$

twenty-eight avatāras, 292, 293

Śiva Vigraheśvara, see Vigraheśvara

ŚIVA, 465, 466

Śivā, 109

Śivabhaktas, 411, 431

Śivadeva II, 538, 539, 608

Śivadeveśvara Bhatṭāraka, 539

Śivadharmaśāstra, 578

Śivaganas, 261

Sivahood, 550

Śivapurāṇa, 189

śivayogin, 578

six-syllable mantra, see sadaksara mantra

skambha (cosmic pillar), 342, 343

Skanda, 264, 265, 403, 535, 605-607

Skandagupta, 51, 144, 146, 307-309, 313-317, 333, 364, 375-378, 413, 414, 415 
Skandapurāna (vulgate, SkP), 180, 181, 182, 185,469

Skandapurāna (original, SP), 180, 181, 185, 186, 194, 197-199, 202 ff., 284, 294-297, 400-402, 431, 468-471, 498, 503, 518, 521, 527-529, 533-535, 537, 539, 542, 553, 554, 559-564, 578, 584, 589, 594, 598, 599, 604, $607-609,610$

A recension, 185, 196, 469, 532, see also Ambikākhanda

$\mathrm{R}$ recension, 185, 196, 469, see also Revākhanda

S recension, 185, 194, 199, 471, 537, see also Nepalese recension

[Skanda]varman, 142

skandha, 4

skeleton, 423, 430, 452, 453, 560

бxló ('shade'), 418

Ślaczka, Anna, 452

Sleemanabad, 347

smarana, 16

śmaśāna (cremation ground), 409, 410, 425, 429, 430, 431, 435, 437, 438, 471-473, 531, 542

Smith, Helmer, 408

Smith, John, 175, 177, 179

Smith, Mary Caroll, 179

Smrti, 140, 182, 184, 231

Smṛtyarthasāra, 52

snake, see serpents

Société des Amis de Marcel Proust, 52

Soḍ̣hala, 85

Sodhala, 320

Sokasallaharana, 406

soma, 291, 293, 294, 297, 554

osoma, 293, 294

Somanātha Temple, 294, 482

Somārya, 332

Somaśarman, 290, 291, 293-297, 554

Somasiddhānta (Pāśupata school), 293, 294, 296

somasūryavamiśa, see Lunar Race

Soma(vamśa) of Mekalā, see Lunar Race

Somavamśin(s), 253, 297

Someśa, 292-294, see also Somaśarman

Somibhațțāraka, 294

Somnāth, 62, 63, 73, 482

Somnāth Temple, 75, 482

Son / Śoṇa / Soṇa (river), 236, 391, 402, 536, 605

Sōndani, 575

Sonepur, 429

Sontakke, Virag, 150

sound, 15, 225, 543, 545

Soundara Rajan, K.V., 571
Southeast Asia, 405, 411, 445, 563

southern face, 413, 490, 506, 520

southern mūrti, 513, 515, 518, 522

sparśa, 225

Spink, Walter, 171, 561

Spring Festival, 606, 607

śrāddha, 108, 332

Śramaṇas, 606

śrāmaṇerī (novice nun), 419, 439

Śrautasūtras, 450, 451

Śrāvast̄̄, 49

Śrī (Lakșmī), 247, 263, 316

Śrī-Harsa, 607

Śrīdeva, 310

Śrīdhara (grandfather of Trivikramabhațta), 86

Śrīdhara Svāmin (author of Subodhinī), 34

Śrīdhara Kavi (father of Trivikrama), 87, 88

Śrīgopālabālastuti, 169

Śrīgupta, 139

śrikantha, 490

Śrīkaṇtha (janapada), 531

Śrīkaṇtha (Nāga), 531

Śrīmahārājacaritra, 66

Śrīparvata, 138

Śrīpura (modern Sirpur), 241, 247-252, 254, 255, 293, 296, 532

Śrīpūrvaśāstra, 285, 292

Śríśaila (deva), 138

Śrīśaila Hills, 171

Śrīsampradāya, 18

Śrīvatsa (Rudra), 285

Śrn்khalika, see Munda-Śrñkhalika

Srugandha (Śrīgandha?), 570

śruti, 160, 354

Stadtner, Donald, 236, 259, 260

Star (tāraka), see Tāraka

State, the, 476, 477, 481

Stein, Burton, 149, 150, 154, 159, 164

stereoscopy, 121

sthalapavitra, 578

sthā $\bar{l} \bar{p} \bar{k} k a, 446$

sthāna (locus), 514, 521, 534, 602

sthānaguru, 290, 291, 296

Sthānapoth̄̄, 92, 93

Sthānasūtra (Thānasuya), 49

Sthāneśvara, 535, 563, 601, 605

Sthāneśvaramāhātmya, 534, 535

sthānu (post), 489

Sthāṇu (Mahādeva), 489, 535

Sthāṇutīrtha, 264, 265, 534, 535

Sthāṇuvața, 534, 535

Sthāṇisívara (modern Thanesar), 531, see also Thanesar and Sthāneśvara 
Stietencron, H. von, 59, 61

stone cists, 408

Stoye, Martina, 186, 193

strīdhana, 363

Stuhr, P., 24

stūpa, 407, 408, 412, 419, 422, 425, 426, 429, 431, 437, 439, 440

sudarśana (artificial lake), 144, 156

Sudarśana (artificial lake near Rāmagiri), 91, 92, 127, 143-145, 147, 157, 371, 372, 414

Sudarśana (artificial lake near Vatsagulma), $144,147,372$

Sudarśana (artificial lake near Junagarh), 144

Sudarśana (god), 127, 134, 145, 371

Sudarśana (cakra Viṣnu), 91, 107, 145

Sudarśanā (princess), 407

Sudarśanārya, 510

Sudāya, 424, 425, 436

śuddhādhvan (Pure Universe), 284-286, 291

Śuddhavidyā (pure tattva), 285

Sudevarāja, 247-249

Sudheśvara, 91, 106

śūdra, 93, 109, 336-339, 350, 409

Sufi(s), 6, 7, 8, 10-13, 15, 18, 19

Sufism, 6-11, 14, 15

Sui Vihar, 417, 426-429, 433-435, 439

Śuka, 230

Sukanyā, 535, 536

Śuklatīrtha, 91, 107

sukr, 6

Sūktimuktāvalī, 86

śūla, 406

Sūlikas, 388

Sultan of Delhi, 90

Sumangalastotra, 169

summum bonum, 60, 77

Sunda, 400, 489

Śunga, 311, 571

Sunna, 69

Sunnis, 68, 70

supreme guru (= Maheśvara), 515

Supuspa(deva), 530

Supuspavarman, 530

Śura family, 236

Śūrabala (alias Udīrṇavaira), 237-240, 247, $248,256,356$

Suradevī, 144

Suranad̄̄ (Sur river), 92, 107, 108, 144

Sūrasāgara, 168, 170

Sūrdās, 168, 170, 173

Suri tombs, 394

Surkh-Kotal, 416, 440

Sūrya, 406, 467

Sūryaghoșa, 250
Sūryavarman, 251-253, 381-383, 389, 532, 533, 602

Sūta, 604-608

Suvarṇanad̄̄, 236

Svacchanda(tantra), 284-287, 515

svadharma, 476, 478

svādhyāya (Veda study), 328, 511

Svāmidāsa (mahārāja), 138, 328

Svāmīghāt, 529

Svāmilladeva, 144, 372

Svāmirāja, 142

Svarlīna, 534

Svarlīneśvara Mandir, 534

svasiddhānta ('own doctrine'), 295, 527, 528 , $532,533,539,563$

svayamātṛnna, 449

svayambhulinga, 471

svayamvara, 186, 187, 191-194, 197, 199, 201

Śveta (form of Śiva), 292

Śveta (king), 337

Śvetāśvatara Upanișad, 517

Swann, Charles, 53

śyena (hawk), 451

śyenaciti, 453, 456, 457

Symeon, 547

tad ekam, 443

Tagare, G.V., 468

Taittirīyāranyaka, 47, 492, 493, 500, 545

Taittirīyabrāhmaṇa, 546, 554

Taittirīyasamhitā, 448, 449

Taittirīyas, 450

Tālā, 247, 256-260, 263, 265

Taleśvara, 399

Taleśvara Copperplate Grant of Dyutivarman, 399

tamas, 224, 228, 386

Tamil, 167, 168, 170, 174, 408, 411, 413

Tandon, Pankaj, 315

Tante Léonie, 53

Tantra, 16, 284, 286

Tantrāloka, 287

tantric, 17, 284, 431, 463, 602

Tapamgiri (Tapogiri), 79, 90, 106, 164

tapas, 91, 191, 336, 480, 497, 524, 525, 590

tapovana, 291, 293

Taradamśaka, 255

Tarain, battle of, 483

Tāraka, 606

tāraka brahman/mantra (saving mantra), 467, 468, 470, 471, 473

Tārīkh-i Alfì, 482

Tatpuruṣa, 492

tattva, 44, 284, 285

tax on pilgrims, 65 
Tejeśa (Rudra), 287

tejas, 401, 498

Tejasoma, 290, 291

Temple Council, see devanikāya

Tewar, see Tripurī

textual criticism, 179, 470

Thānasuya, see Sthānasūtra

Thanesar (Sthāṇvīśvara / Sthāneśvara), 63, 421, 528, 531, 534, 535, 553, 563, 602, 605

Thapar, Romila, 455

Thaplyal, Kiran Kumar, 308, 382

theodicy, 59

theophany, 8

theôsis, 543

thousand-and-eight names (of Śiva), 524

Tibet, 608

Tieken, Herman, 411

Tilak, Bal Gangadhar, 478

tilavācanaka, 332

Tilottamā, 400, 401, 489-490, 498, 521

time, concept of, 8, 61

Times of India, 75

Tirodī Plates of Pravarasena II, 325

tìrtha, 338, 410, 421, 484, 533, 608, see also holy places

Tīrthāink, 184

tīrthaikara, 51, 417, 426

Tìrthavivecanakāṇda, 468, 469, 533

Tìrthayātrāparvan (MBh), 50

Tirumoli, 167

Tiruttani, 522

Tiruvorriyur Temple, 294

Tiruvuru, 252

Tivaradeva, 235, 247, 251-253

Tiwari, Jagdish Narain, 410

Tolstoy, Leo, 477

Toramāna, 598

torana, 522, 523, 525, 526, 568, 569, 573, $574,576,597$

tortoise, 227, 449, 454, 456, 542

Tranakayira (mahārathi), 415

Trāta (mahāsattrapati), 399

tree (cosmic, world), 335, 343

Tretāyuga, 48, 336, 554

trickster, 544

Tripura (Triple City), 190, 191, 193, 194, 386,474

Tripurī (modern Tewar), 146, 150, 314, 325, 364

Tripurīvāsaka, 325

trisamudranātha, 131, 138, 310

Triṣaștiśalākāpuruṣacaritra, 425

Tristhal̄̄setu, 467

Trivandrum (library), 90

Trivara(nagara) (modern Tiruvuru), 251, 252
Trivikrama (Viṣnu), 80, 83-85, 143, 334 342-344, 353-358, 361, 365, 368-372

Trivikrama (poet, son of Śrīdhara Kavi; author of the Madālasācampū), 83-88, 163,165

Trivikramabhatta (grandson of Śrīdhara; author of the Nalacampū), 85, 86

Trivikrama Temple (Ramtek), 356, 357, 364-367, 371, 372, 414

Tromp, Hylke, 57

tryakșa, 499

Tsuchida, R., 562

Tulapadraka, 290, 291

Tulsī Ghāṭ (Benares), 467

Tuls̄idās, 18, 65, 463, 464, 466, 467, 473, 474

Tumain, 310

Tumain Inscription of Kumāragupta and Ghatotkacagupta, G.E. 116, 138-141, 308, 310, 359

Tumbavana (modern Tumain), 310

Tunga dynasty, 402

turtle, see turtoise

Turturiya (temple), 245, 246

Turuska, 482, 483

turuṣkadañda, 483

Tusām Rock Inscription, 329

Tuṣāspha (Yavana king), 144

tūsnīm-yuddha (silent fight), 476

Tvastar, 60

Uccakalpa, 328

Udayagiri, 319-321, 323, 326, 327, 329, 330, 333,334

Caves (4, 5, 6 and 8), 319, 320

Udayagiri Cave Inscription, Year 106, 320

Udayagiri Cave Inscription of Candragupta II, Year 82, 138, 319, 320

Udayana (logician), 518

Udayana (king) of Vatsa, 248, 250

Udayasena (mahāsāmanta), 391, 392, 394 397,398

Udbhavarāśi, 292, 532, 533

Udīrṇavaira, see Ś̄urabala

udumbara wood, 449

udyāna, 471

ugra, 490-492

Ugra (Rudra), 190, 285

Ujjayan̄̄ / Ujjayin̄̄ (modern Ujjain), 108, 169, 170, 295, 302, 418, 423, 430, 431, 435, 438, 527-529, 542, 560, 562-565, 602

$u k h \bar{a}$ (fire-pot), 449

'ulamā', 9, 10

ulmuka (firebrand), 560

Ulūka, 294 
ulūkhalaka, 449

Ulysses, 337

Umā, 187, 190, 191, 194-197, 490, 492

Umrāvgiri, Gosāīn, 70

Unfinished Durg Plate, see Mohallā Plate

union with God, 517, 525, see also yoga

Unterdrückungsyoga, 37, 38

upadhmān̄̄ya, 119, 131

upahārasūtra, 518

Upamanyu, 498

Upamita ( $\bar{c} c \bar{a} r y a), 328$

Upamiteśvara (linga), 287, 328, 494

upanayana, 505, 506, 510, 512, 513, 519, 581

Upanișad(s), 27, 477, 511, 585

Upasunda, 489

upāya, 465

Urban II (Pope), 58, 71, 72

Ürjayat, 388

Urvaśī, 581

Usas, 190

uṣñ̄sa, 261, 266, 437, 490492

Utkala, 253

Utkalakhanda, 181

Uttar Pradesh, 522, 563

Uttarakhand, 399

Vāgīśabhaț̣a, 294

Vāgīśvarī, 285

vāhana, 263

Vaidya (village), 539

Vaidyanātha, 89

vaijayikadharmasthāna, 325, 496

Vaikhānasa, 599

Vaikuntha (Visnu's Paradise), 20, 52, 71

Vaimala (Lākula division), 287, 288, 561

Vainyā River, 332, see also Beṇn̄ā and Wainganga

Vainyapura, 87, 88

Vainyāpurasthāna, 332

vairāgin, 66

Vaiśālī, 137, 307, 310

Vaiṣnava(s), 16, 66, 133, 155, 163, 320, 329, $342,343,400,432,464,465,467,468,520$, $534,542,550,551,571,588$

Vaiṣnava bhakti, 16-18, 161, 164, 550, 551

Vaișnava Saṃhitās, 16

Vaișnavakhanda, 182-184

Vaisnavism, 16, 81, 464, 550

Vaiśravana, 407

vaiśya, 450

Vaivasvata, 386

Vājapeya sacrifice, 524

Vājasaneya/yin (White Yajurveda), 290, 332, $333,354,449,450$

Vājimedhatīrtha, 91, 107 vajra, 187, 264

Vajrayāna, 13

Vākātaka(s), 79-81, 92-94, 113, 114, 118-120, 127, 137, 139-147, 149, 150, 152-154, 156-158, 160-163, 165, 166, 170, $171,173,243-246,251,256,259,262,264$, $301,302,306,311,312,314-316,323,324$, 326, 329-334, 340-344, 347, 351, 352, 358, $361,362,364,373-375,378,413,414,417$, 432, 434, 435, 438, 495, 496

Vākāṭaka (Eastern or Main Branch), 152, $153,157,306,314,317,323,324,333,371$, 372

Vākāțaka (Western or Vatsagulma Branch), $144,146,147,157,314,317,325,328,333$, 372

Vākātaka-Gupta relationship, 115, 145-147, $312,314-318,357-364$

Vākpatirāja, 482, 531

vaktra, 492

Vallabhadeva, 340, 400

Vālmīki, 339

Vāmadeva, 492

Vāmana, 353, 354, 370

Varadā River (Warda), 312-314

varadamudrā, 173, 332

Varāha, 80, 93, 109, 155, 156, 319, 320, 322, $330,333,334,365,372$

Vārāhaśrautasūtra, 448

Varāha Temple (Ramtek), 365

Varāhadeva (minister), 119, 120, 127, 130, 147

Varāhamihira, 460, 482

Vārānasī, 236, 391, 403, 463, 464, 465, 467, 470, 471, 473, 483, 484, 533, 534, 602-606, 608, see also Benares and Kāśí

Vārāṇasīmāhātmya, 468, 469, 470, 471, 473, 533,534

Vareśvara (Rudra), 292

Varmabhațā, 418

varnāśrama, 524, 531

Varuna, 106, 263, 265, 406, 585

Varunatīrtha, 91, 106

vāsaka (army camp), 314, 325, 364, 606

Vāsațā, 251-254, 532, 539

Vaṣațāra (Rudra), 292

Vasistha, 534

Vāstoṣpati, 446, 458

vāstu, 435, 460

vāstunāga, 434, 531

Vastupāla, 413

Vāstupratiștha, 446

vāstup $\bar{u} \bar{a}, 460$

Vāstupuruṣa (Man of the Homestead), 435, 443, 459-462 
Vāstupurusamandala, 460, 462

Vāstuśamana (animation sacrifice), 445-447

Vāstuśānti (appeasement sacrifice), 445, 446 vāstuyajña, 447

Vasu, 265

Vāsudeva, 163, 173, 329, 375-377, 414, 516, 556,570

Vatsa, 248, 294, 535, 536

Vatsadevī, 538, 539, 608

Vatsagulma (modern Wasim), 144, 147, 314, $328,329,372$

Vatsarāja, 239, 248

vātsalyabhāva, 168

Vātsyāyana(s), 49, 535, 536

Vaudeville, Charlotte, 6, 10, 15, 16

Vaula, 160

Vāyupurāṇa, 193, 294, 559

Vāyurakṣita, 307, 308

Vedānta, 30

Veda(s), 38, 55, 56, 446, 464, 506, 511, 524

vedi, 423, 457

Vedic, 65, 152, 192, 196, 197, 199, 342, 353, $354,405,409,410,412,429,439,440,446$, $447,460,505,512,517,542-545,548,594$ Vedic initiation, 505, 512, 513

Vedic rituals, $73,152,153,342,353,415$, $456,506,508,513$

Vedism, 452

Vediśrī, 415

Ven̉kațeśvara Press, 194, 195

Vetālasādhana, 531

VHP, see Visva Hindu Parisad

Via Dolorosa, 551

Victoria and Albert Museum, 437

Vidarbha, 81, 142, 149, 150, 153-155, 158, $171,173,259,282,306,309,312-314,316$, $323,327,334,335,337,347,349,374,418$

Vidiśā (modern Besnagar), 302, 305-308, 311-313, 315, 317, 323, 359, 364, 371

Vidisha District, 305

vigraha, 17, 497

Vigraheśa/eśāna/eśvara (Rudra), 285, 291-293

vihāra (Buddhist monastery), 250, 251, 255, 321

vijayādaśam̄̄, 482

Vijayanagara, 80, 92, 149, 164, 482

vijigișu, 55, 61, 476

vikrama (action), 334

Vikrama Era, 397, 570

Vikramendravarman II (Vișnukuṇịin), 251

Vilāsatunga, 256

Vima/Vema Kadphises, 239, 415, 416

Vima Taktu, 416

Vinayapatrikā, 464, 473
Vindhya(s), 91, 250, 317, 323, 336, 337, 388, $391,401,429$

Vindhyaśakti II, 325

Vindhyavāsin̄̄, 605

Vinīta, 402

Vinītarāśi, 532

Vinīteśvara (temple), 402

Viniteśvaramatha, 397-400

Vin̄iyā (Vin̄itā), 51

Vinoba Bhave, 170

Vipākasūtra, 51

Vīrabhadra, 524

viraha (separation), 17, 18, 550

Virāha(dāsa), 571

Vīrasena, 138, 319, 320

Vīrattāneśvara Temple, 522

virtù, 162

Virūḍha, 406, 407

Virūpākṣa, 406, 407

Viśākha, 264

Viśākhadatta, 303, 304, 603

Viśiștāàvaita, 8, 17

Viṣnu, passim, 52, 64, 65, 71, 81, 86, 94, $106,109,128,135,138,139,143,144$, $153,156,159,161,170,189,195,196$, $243,253,254,319,320,326,330,333$, $339,341,342,354,361,371,375,465,498$, 570, 571, 589, 590, 602, 604, see also avatāra (Vișnu), the individual avatāras, Bhagavat, and Rāmagirisvāmin

Viṣnu Cakrapāṇi, 145

Viṣnu-Nārāyaṇa, 94, 319, 327, 330

Viṣnu-Śārngin, 375

Vișnudatta, 571

Viṣnudharmottarapurāna (VDhP), 406, 407, 413, 419, 421, 424, 437, 438, 440, 493, 499, $503,519,581$

Vișnugupta, 539

Viṣṇukuṇḍin(s), 170, 171, 173, 251, 252

Viṣnupada/pāda (Viṣnu's footprint), $341-344,570$

Viṣnupurāṇa, 169, 181, 283, 604

Viṣnuvardhana, 588

Visva Hindu Parisad (VHP), 73, 74, 76

Viśvakarman, 489

Viśvāmitra, 39, 534

Viśvarūpa (brahmin), 297

Viśvavarman, 308, 570

Viśveśvara, 468

vitarkamudrā, 521, 522

Vițthal Mandir (Ramtek), 90

Vivāgasuya, 51

Viyagappa, Ignatius, 23

viyoga, 543

Vogel, J.Ph., 406 
Vraja, see Braj

vrata, 287, 524, 525, 545, 558, see also

Mahāvrata and Pāśupatavrata

Vrindavan / Vṛndāvana, 18-20, 52, 551

Vrșa (bull), 534

Vrșan, 534

Vrșini, 329

Vrrtra (Indra), 387

Vyāghrarāja, 240, 241, 242

vyākhyānamudrā, 521, 561

Vyāpaśiva, 296

Vyāsa, 37, 187, 230, 585, 586

Wackernagel, Jacob, 517

Wadgāon Plates of Pravarasena II, Year 25, 325

Wainganga River, 324-326, 332, see also Vainyā and Beṇnā

Wainganga Plain, 149, 150

Wājid ‘Alī Shāh, 68, 69

war, 475, 479, 481, 482

warfare, 475, 476, 479, 481

Warda (river), see Varadā River

Warder, A.K. 303, 304, 313

warrior ascetics, 13, 63, 64, 70

Warrior Sufis, 11

Wasim / Washim, see Vatsagulma

water reservoir, 134, 143, 371, see also sudarśana

Weber, Max, 58

wedding of Śiva and Pārvatīi, 186, 192

Wellsted, T.A., 432

Wessing, Robert, 445, 447, 452

West Bengal, see Bengal

Wezler, A., 185, 194

White Yajurveda, 450, 509, 510, 512

Wikipedia, 601

Wilkins, Charles, 31

Williams, Joanna, 149, 150, 156, 173, 244, $259,260,320,367,392,522-524,573,574$, $576,587,588,595$

Willis, Michael, 236, 320, 330, 609

Wilson, Frances, 169

Wilson, H.H., 33

Witzel, M., 180

Xenophanes, 443, 462

Xiyuji, 51

Xuanzang, 51, 255, 534, 562, 603

Yādava(s), 80, 83-86, 88, 89, 92, 150, 158-166
Yādava inscription, 84, 339, 340, 341, 350

Yadu, 89, 159, 160

yajamāna, 152, 451, 459

yajña, 132, 190, 500, 524

Yajña, 189, 534

Yājñavalkya, 465

Yājñavalkyasmrti, 408

yajñopavīta, 508, 510

Yakșa/yakșa, 92, 93, 265, 340, 349, 350, 407, 597

Yakșas (Buddhist), 406

Yama, 406, 407, 450, 592

Yamagarta-mandala, 402

Yamunā, 20, 606, 607

Yaśodā, 20, 167, 168, 173

Yaśodattā, 419

Yaśodharman, 571, 588, 598

Yaśovarman of Kanauj, 482

Yaśovatī (queen), 405

yasti, 406, 417, 419, 421, 423, 424, 426-428 437, 439, 440, 457

yaștipratișthāna, 428

Yatīndramatadīpikā, 52

Yaudheyas, 302

Yavana(s), 144, 311, 569

yavīyasī, 130

year, 507, 508, 518

yoga / Yoga, 9, 11-13, 20, 36, 37, 39, 42,

230, 295, 490, 497, 517, 520, 524, see also

Pāśupata yoga

Yogasūtra, 36, 37

yogavidhi, 544

yogavidy $\bar{a}, 585$

Yogeśvara, 573, 583, 584, 586

Yogeśvarī Cave, 530, 561

yogi(n)(s), 11-13, 15, 16, 18, 19, 62, 164, 386, 412, 431, 472, 490-492, 560, 602, 606, 608

Yokochi, Yuko, 352, 400, 401, 537, 594, 610

yuddha, 476, see also kūta-, prakāśa-, tūṣnīmyuddha

Yudhișthira, 230, 328, 398, 399, 585, 586

yuga, 409, 554

Yugapurāna, 49

Yugaśaila, 452

Yuktidīpikā, 227

уйpa, 342, 424, 427, 428

yurodivyj (юродивый), 548

yuvarāja, 314, 315, 329

Zehmke, Britta, 187, 193

Zwalf, W., 424 